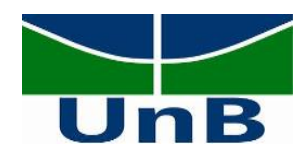

UNIVERSIDADE DE BRASÍLIA - UNB

CENTRO DE ESTUDOS AVANCADOS MULTIDISCIPLINARES - CEAM

PROGRAMA DE PÓS-GRADUAÇÃO EM DESENVOLVIMENTO, SOCIEDADE E

COOPERAÇÃO INTERNACIONAL - PPGDSCI

Políticas Públicas para Juventude: Um estudo de caso com egressos do ProJovem Urbano e sua inserção no mercado de trabalho no Distrito Federal.

EDISON BEWIAHN

BRASÍLIA/DF

JULHO/2015 


\section{EDISON BEWIAHN}

Políticas Públicas para Juventude: Um estudo de caso com egressos do ProJovem Urbano e sua inserção no mercado de trabalho no Distrito Federal.

Dissertação de mestrado apresentada ao Programa de PósGraduação em Desenvolvimento,Sociedade e Cooperação Internacional da Universidade de Brasília, vinculada à Linha de Pesquisa Desenvolvimento e Políticas Públicas, como requisito para a obtenção do título de Mestre em Desenvolvimento, Sociedade e Cooperação Internacional sob orientação da Professora Dra. Leila Chalub Martins

BRASÍLIA/DF

JULHO/2015 


\section{Políticas Públicas para Juventude: Um estudo de caso com egressos do ProJovem Urbano e sua} inserção no mercado de trabalho no Distrito Federal.

Dissertação de mestrado apresentada ao Programa de Pós-Graduação em Desenvolvimento, Sociedade e Cooperação Internacional da Universidade de Brasília, vinculada à Linha de Pesquisa Desenvolvimento e Políticas Públicas, como requisito para a obtenção do título de Mestre em Desenvolvimento, Sociedade e Cooperação Internacional sob orientação da Professora Dra. Leila Chalub Martins.

Brasília, 20 de julho 2015.

\section{COMISSÃO EXAMINADORA}

Professora Dra. Leila Chalub Martins

Orientadora - Universidade de Brasília (UnB)

Professor Dr. Daniel Jaime Capistrano de Oliveira

Examinador Externo - Pesquisador do Instituto Nacional de Estudos e Pesquisas Educacionais Anísio Teixeira (INEP)

Professora Dra. Ana Maria Nogales Vasconcelos

Examinadora - Universidade de Brasília (UnB)

Professor José Walter Nunes

Suplente - Universidade de Brasília (UnB) 
A minha mãe, pessoa de quem me orgulho e que me serve de inspiração. 


\section{Agradecimentos}

Agradeço a Professora Leila Chalub Martins, pela ajuda comprometimento e otimismo dispensado durante todo o tempo em que estivemos juntos para a construção desta dissertação.

Aos professores, Ana Maria Nogales Vasconcelos, Daniel Jaime Capistrano de Oliveira, José Walter Nunes por contribuírem com seus conhecimentos para a constituição da banca de avaliação para que os conhecimentos obtidos e aplicados neste projeto pudessem ser avaliados.

Aos meus colegas de curso, que estiveram comigo durante esta jornada, e partilharam das mesmas ansiedades, e me ajudaram a progredir nesses meses.

A todos os professores do Programa de PGDSCI, e da Faculdade de Educação que partilharam de seus conhecimentos e foram importantes para o meu crescimento acadêmico.

Às funcionárias da secretaria de PPGDSCI, que sempre estiveram dispostas a ajudar quando necessário.

À minha companheira de sobrevivencialismo, que esteve comigo desde o início de minha jornada, e sem quem, este trabalho não teria sido possível.

Aos meus amigos que deixei em SP e no MS, que me incentivaram a entrar para o programa e me apoiaram até à conclusão.

À minha família, que sempre foi inspiração para que buscasse progresso contínuo em minha vida. 


\section{RESUMO}

O Projovem Urbano é uma política pública de iniciativa do governo federal e na sua primeira versão em 2005, tinha como objetivo oferecer escolarização e qualificação profissional a jovens entre 18 a 24 anos de idade que não haviam concluído o ensino fundamental. Em 2008 o Programa passou por reformulação ampliando o atendimento para jovens entre 18 e 29 anos que saibam ler e escrever. O Programa tem como eixos estratégicos a elevação da escolaridade, a qualificação profissional e a participação cidadã. Em 2012 a Coordenação Nacional passou para o Ministério da Educação. No Distrito Federal, desde a sua primeira edição em 2005, teve dificuldades na implementação, principalmente no que se refere à qualificação profissional. Diante disso, a presente dissertação tem como objetivo mostrar de que forma esta política pública contribui para que jovens, egressos do programa da edição de 2012, possam ser inseridos no mercado de trabalho. Para buscar respostas foi utilizada a metodologia qualitativa e a quantitativa. Os dados quantitativos foram extraídos do SIMEC - Sistema Integrado de Monitoramento Execução e Controle do Ministério da Educação, os dados se referem ao número de matriculados, desistentes e concluintes do Programa. Foram ainda, realizadas 44 entrevistas com os estudantes egressos do Programa. Realizou-se também entrevistas com o gestor local e o gestor nacional do Projovem Urbano do MEC. As entrevistas com os egressos foram analisadas e apresentadas em gráficos, já as entrevistas realizadas com os gestores foram degravadas e analisadas. A elaboração dessa dissertação propiciou verificar que no DF é preciso ter um acompanhamento mais eficaz do Programa, já que se trata de recursos federais. O Programa não consegue atingir as metas propostas e o número de estudantes concluintes é muito baixo, além disso dos 44 entrevistados - no que se refere à inserção no mercado de trabalho - apenas $18 \%$ afirmaram que houve melhora.

Palavras-chaves: Projovem Urbano, qualificação profissional e políticas públicas para juventude. 


\section{ABSTRACT}

The Projovem Urban is a public policy initiative of the federal government and its first release in 2005, aimed to provide education and vocational training to young people aged 18-24 years who had not completed elementary school. In 2008 the Program underwent redesign expanding the service to young people between 18 and 29 who can read and write. The Program's strategic axes elevation of education, vocational skills and citizen participation. In 2012 the National Coordination passed to the Ministry of Education. In the Federal District, since its first edition in 2005, it had difficulties in implementation, especially with regard to professional qualifications. Therefore, the present work aims to show how this public policy contributes to youth, the 2012 edition of the program graduates, can be inserted in the labor market. To seek answers was used the qualitative and quantitative methodology. Quantitative data were extracted from SIMEC - Integrated Monitoring System Implementation and Control of the Ministry of Education, the data refers to the number of enrolled, dropouts and graduates of the program. I was, also, made 44 interviews with graduated students from the program. It also conducted interviews with the local Projovem manager and the national Projovem Urban manager from MEC. Interviews with graduates have been analyzed and presented in graphs, as the interviews with managers were wrote down and analyzed. The preparation of this dissertation led to verify that in the DF is necessary to a more effective monitoring of the Programme, as it comes to federal resources. The program fails to achieve the goals and the number of graduating students is very low, besides that the 44 respondents with regard to integration into the labor market - only $18 \%$ reported an improvement.

Keywords: Projovem Urbano, professional training and public policy for youth. 


\section{LISTA DE FIGURAS}

Figura 1: Total de matrículas na EJA integrada à Educação Profissional...................................................35

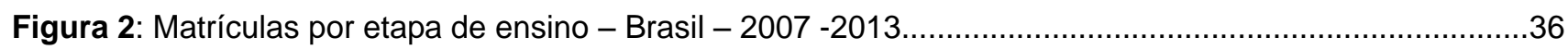

Figura 3: Matrículas no Ensino Fundamental - Brasil e regiões - 2013.................................................36

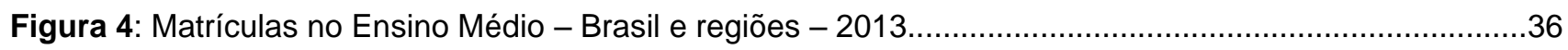

Figura 5: Estrutura de formação dos núcleos e Estações Juventude do Projovem........................................48

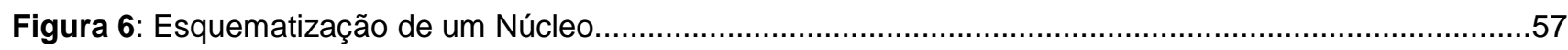

Figura 7: Projovem Urbano nos Estados e Municípios .............................................................................58

\section{LISTA DE QUADROS}

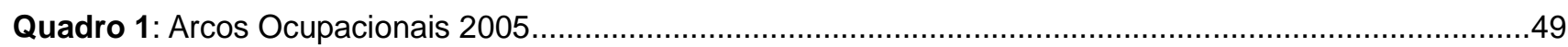

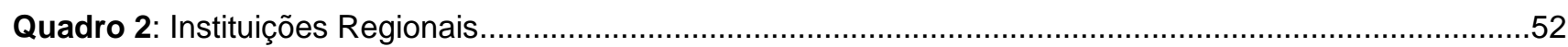

Quadro 3: Componentes da Qualificação Profissional........................................................................58

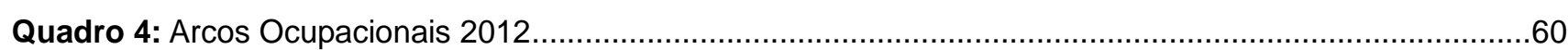

Quadro 5: Comparação entre as edições do Projovem em 2005, 2008 e 2012 ........................................61

Quadro 6: Taxas de participação e de desemprego dos jovens de 16 a 24 anos e da população total acima de 25 anos no DF. 65

Quadro 7: Distribuição dos jovens ocupados de 16 a 24 anos segundo escolaridade no DF........................67

Quadro 8: Distribuição dos jovens ocupados de 16 a 24 anos segundo setor de atividade no DF..................67 


\section{LISTA DE GRÁFICOS}

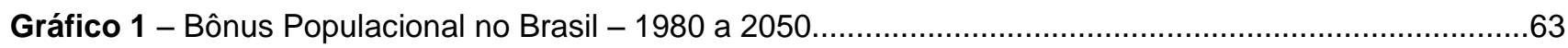

Gráfico 2 - Metas de matrículas e alunos concluintes, Distrito Federal, 2012 ............................................73

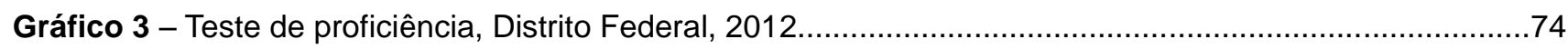

Gráfico 4 - Distribuição por etnia e sexo, Distrito Federal, 2012 ............................................................

Gráfico 5 - Distribuição por idade, Distrito Federal, 2012 ................................................................. 75

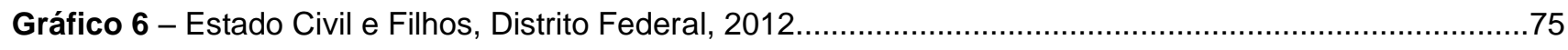

Gráfico 7 - Solteiros com filhos, Distrito Federal, 2012 ................................................................76

Gráfico 8 - Possui alguma ocupação, Distrito Federal, 2012 ...................................................................76

Gráfico 9 - Por que se interessou pelo Projovem, Distrito Federal, 2012 .............................................77

Gráfico 10 - Até que série havia estudado antes do Projovem, Distrito Federal, 2012................................77

Gráfico 11 - Expectativa sobre o arco ocupacional, Distrito Federal, 2012 ............................................78

Gráfico 12 - Conseguiu emprego ou melhorou no emprego, Distrito Federal, 2012 ...................................78

Gráfico 13 - Opiniões sobre o projovem e arco ocupacional foram confirmadas?, Distrito Federal,

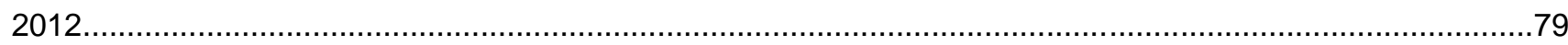

Gráfico 14 - Por que largou os estudos, Distrito Federal, 2012 ..........................................................79

Gráfico 15 - Até que série seus pais estudaram, Distrito Federal, 2012 ............................................. 80

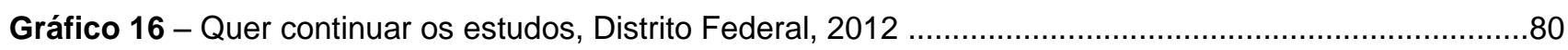




\section{LISTA DE ABREVIATURAS E SIGLAS}

CAED Centro de Avaliação da Educação

CEAM Centro de Estudos Avançados Multidisciplinares

CEB Câmara de Educação Básica

CF Constituição Federal

CNE Conselho Nacional de Educação

CNJ Conselho Nacional da Juventude

CNPq Conselho Nacional de Desenvolvimento Científico e Tecnológico

Conae Conferência Nacional da Educação

CSJ Consórcios Sociais da Juventude

DIEESE Departamento Interministerial de Estatística e Estudos Sócioeconômicos

EC Emenda Constitucional

ECA Estatuto da Criança e do Adolescente

EJA Educação de Jovens e Adultos

FIC Formação Inicial e Continuada

FTE Formação Técnica Específica

FTG Formação Técnica Geral

FTG Formação Técnica Geral

FUNDAR Fundação Darcy Ribeiro

GDF Governo do Distrito Federal

GT

Grupo de Trabalho Interministerial da Juventude

IBGE Instituto Brasileiro de Geografia e Estatística

INEP Instituto Nacional de Estudos e Pesquisas Educacionais Anísio Teixeira

IPEA Instituto de Pesquisa Economica Aplicada

IR Instituições Regionais

LDB Lei de Diretrizes e Bases da Educação Nacional

MEC Ministério da Educação

OMS Organização Mundial da Saúde

OPS Organização Panamericana da Saúde

PDAD Pesquisa Distrital por Amostra de Domicílios

PEA População Economicamente Ativa

PED Pesquisa de Emprego e Desemprego

PIA População em Idade Ativa

PIB Produto Interno Bruto

PLA Plano de Ação Comunitária

Pnad Pesquisa Nacional por Amostragem de Domicílios

PNE Plano Nacional da Educação

PNJ Política Nacional de Juventude

PNPE Programa de Estímulo ao Primeiro Emprego 
POP Projeto de Orientação Profissional

PPGDSCI Programa de Pós-Graduação em Desenvolvimento, Sociedade e Cooperação

ProJovem Programa Nacional de Inclusão de Jovens e o Projovem

PRONATEC Programa Nacional de Acesso ao Ensino Técnico e Emprego

PROSAD Programa Saúde do Adolescente e do Jovem

SECADI Secretaria de Educação Continuada, Alfabetização, Diversidade e Inclusão

SEDEST Secretaria de Estado de Desenvolvimento Humano e Social

SGPR Secretaria Geral da Presidência da República

SIMEC Sistema Integrado de Monitoramento Execução e Controle do Ministério da Educação

SINAJUVE Sistema Nacional de Juventude

SMA Sistema de Monitoramento e Avaliação

SNJ Secretaria Nacional da Juventude

UF Unidade Formativa

UnB Universidade de Brasília

UNESCO Organização das Nações Unidas para a Educação, a Ciência e a Cultura.

UNFPA Fundo de População das Nações Unidas 


\section{Sumário}

INTRODUÇÃO

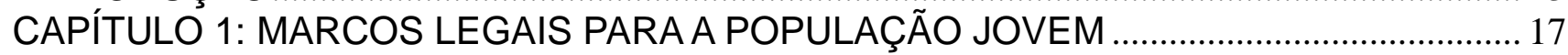

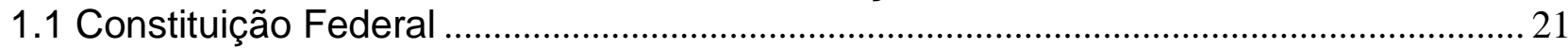

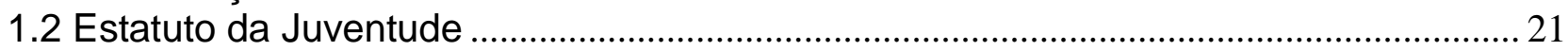

1.3 Plano Nacional de Educação - PNE - Lei 13.005 de 25 de junho de 2014. .................. 34

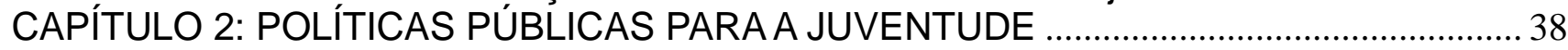

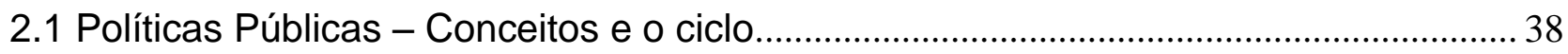

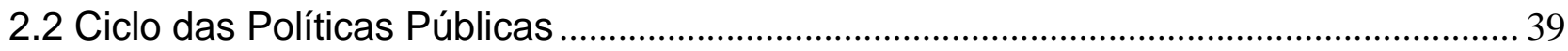

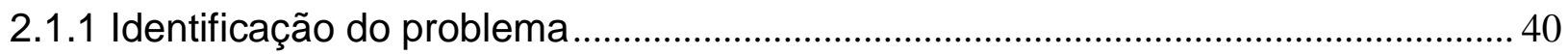

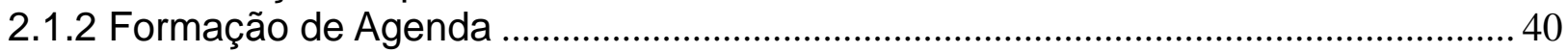

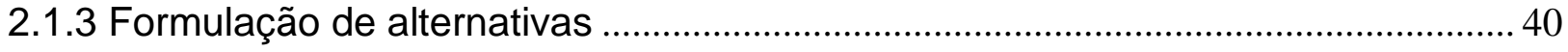

2.1.4 Tomada de decisão ........................................................................................... 41

2.1.5 Implementação da Política Pública .......................................................................... 41

2.1.6 Avaliação de Políticas Públicas................................................................................... 41

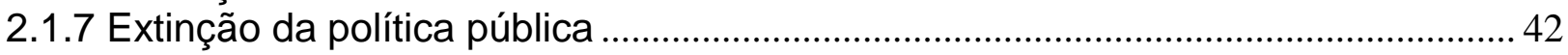

2.2 Histórico das políticas públicas para a juventude no Brasil .............................................. 43

CAPÍTULO 3: PROJOVEM URBANO, POPULAÇÃO JOVEM E O BÔNUS

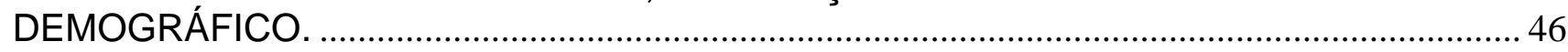

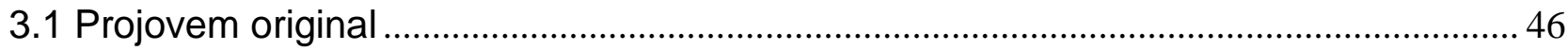

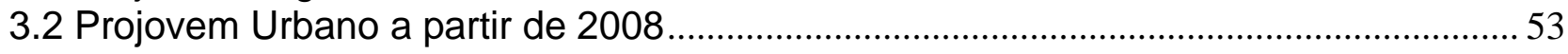

3.3 Projovem Urbano - Ministério da Educação ..................................................................... 54

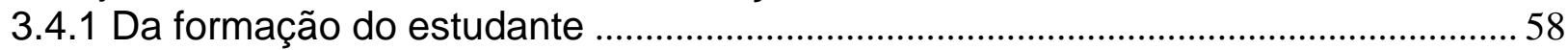

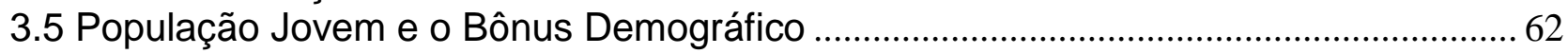

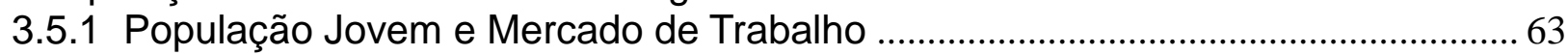

3.5.2 Mercado de Trabalho para os Jovens no Distrito Federal................................................... 65

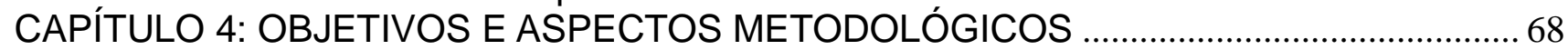

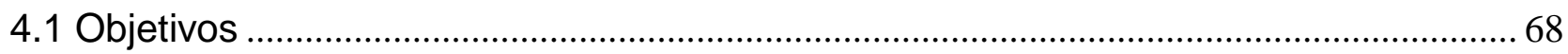

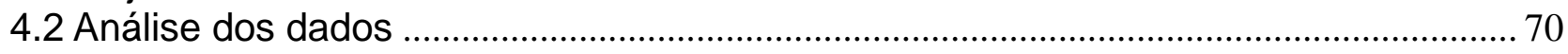

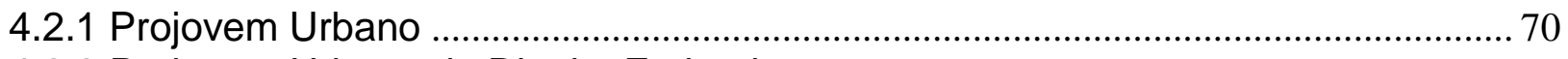

4.2.2 Projovem Urbano do Distrito Federal...………………………………………….... 71

4.3 Perfil dos estudantes do Projovem Urbano do Distrito Federal ........................................ 73

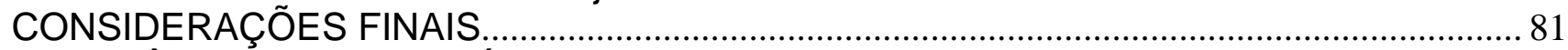

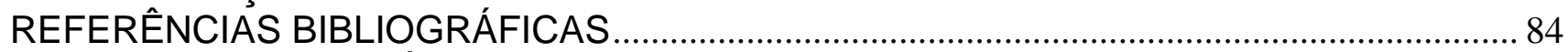

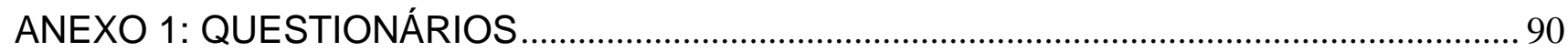

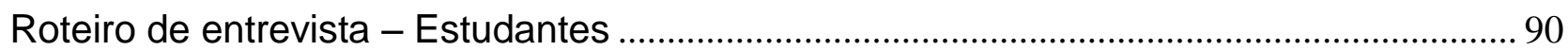

Roteiro de entrevista - Coordenador nacional(MEC)/Gestor do Projovem Urbano .......... 92

ANEXO 2: DIRETRIZES OPERACIONAIS - Parecer CNE/CEB № 11/200 ……….................93

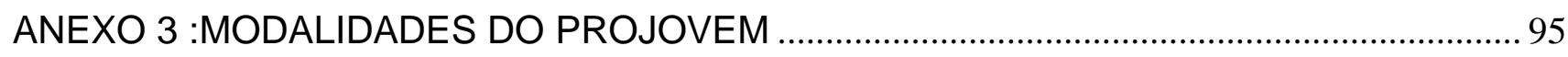

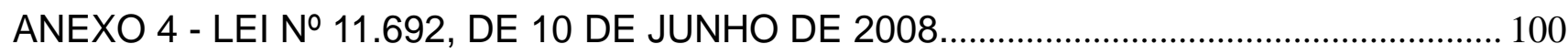

ANEXO 5 - DECRETO № 26.132, DE 24 DE AGOSTO DE 2005............................................ 105 


\section{INTRODUÇÃO}

A presente dissertação faz um estudo sobre o ProJovem ${ }^{1}$ Urbano, e busca mostrar de que forma esta política pública contribui para que jovens, egressos do programa da edição de 2012, possam ser inseridos no mercado de trabalho.

O interesse pelo tema surgiu a partir da experiência em trabalhar como aplicador do teste diagnóstico², do Exame Final Nacional Externo³ de 2006 a 2008 e como pesquisador da pesquisa dos evadidos ${ }^{4}$ em outubro de 2006, que consistia na aplicação de questionários para jovens que freqüentaram o ProJovem e por algum motivo deixaram o programa, na cidade de Campo Grande, Mato Grosso do Sul, MS.

A partir desta experiência surgiu o seguinte questionamento: de que forma o Projovem Urbano pode contribuir para que os jovens possam ser inseridos no mercado de trabalho? E mais especificamente: como a qualificação profissional recebida no Programa pode ajudar os jovens a serem inseridos no mercado de trabalho e se aqueles que conseguiram ser inseridos estão aplicando os conhecimentos adquiridos em sua profissão?

Inicialmente a proposta era estudar o Projovem Urbano em Campo Grande, MS, contudo, houve uma ocasião, em que a supervisora do Sistema de Monitoramento e Avaliação do Programa do DataUnB, comentou que os estudantes do Distrito Federal, da edição de 2005, tiveram problemas com a qualificação profissional. Diante disso, o foco da pesquisa passou a ser o Distrito Federal.

Porém, face às dificuldades em localizar os gestores da edição de 2005 do Programa no Distrito Federal, visto que inicialmente era coordenado pela SEDEST - Secretaria de Estado de Desenvolvimento Humano e Social, optou-se então em pesquisar a edição de 2012. A transição da Coordenação-Geral do Programa - da Secretaria Nacional de Juventude para o Ministério da Educação, também influenciou a escolha por esta edição.

No Brasil em 2008 existiam 50,2 milhões de jovens entre 15 e 29 anos, o que representava $26,4 \%$ da população, de acordo com o Institudo de Pesquisa Econômica Aplicada - IPEA, 2009. Targino (2011) cita os estudos do INEP - Instituto Nacional de Estudos e Pesquisas Educacionais Anísio Teixeira (2008), em que 3,4 milhões de jovens brasileiros entre 18 e 24 não estudavam e tampouco trabalhavam. Pesquisa do IPEA (2009) com relação aos estudos, menciona que o processo de escolarização da maioria dos jovens brasileiros é marcado por desigualdades e oportunidades limitadas. Muitos jovens começam a estudar e por vários motivos acabam interrompendo seus estudos, caracterizando um percurso educacional irregular.

Com relação ao desemprego, segundo o IPEA (2009), no Brasil, os jovens entre 15 e 24 anos apresentam taxas de desemprego significamente maiores que os adultos; em 2006, enquanto a taxa de desemprego era de $5 \%$ entre os adultos de 30 a 59 anos,

\footnotetext{
${ }^{1}$ Projovem - Programa Nacional de Inclusão de Jovens

${ }^{2}$ Exame aplicado no início do curso que tem a função diagnóstica. (Sofiati Teixeira, 2011)

${ }^{3} \mathrm{O}$ Exame final tem a função somativa, visando à certificação, ou seja, é condição para o aluno habilitarse à certificação no ensino fundamental. (Sofiati Teixeira, 2011)
} 
observavam-se índices de $22,6 \%$ entre os jovens de 15 a 17 anos, $16,7 \%$ entre 18 e 24 anos, e $9,5 \%$ entre 25 e 29 anos.

Diante desta situação, com a preocupação de inserir os jovens no mercado de trabalho e de aproveitar o bônus demográfico ${ }^{5}$, inseriu-se na agenda, políticas públicas para juventude ${ }^{6}$.

Em 2004 foi criado o Grupo de Trabalho Interministerial da Juventude -GT ${ }^{7}$, que identificou nove desafios que deveriam pautar a Política Nacional da Juventude, entre eles destacam-se: ampliação do acesso e permanência na escola e preparação para o mercado de trabalho (Schmidt et al, 2010). Em 2005 foi criada a Secretaria Nacional da Juventude - SNJ, o Conselho Nacional da Juventude - CNJ, e o Programa Nacional de Inclusão de Jovens e o Projovem. Em 2007 as ações do GT, SNJ, CNJ e do Programa Nacional de Inclusão de Jovens e o Projovem foram reunidas em um único programa: o Projovem integrado (Projovem Urbano, Projovem Campo, Projovem Trabalhador e Projovem Adolescente) que entrou em vigor em janeiro de 2008.

O Projovem Urbano, na sua primeira versão em 2005, tinha como objetivo oferecer escolarização e qualificação profissional a jovens entre 18 e 24 anos de idade que não haviam concluído o ensino fundamental. Contudo o programa teve que passar por reformulação para atender a uma das dimensões da Política Nacional de Juventude, que é a dimensão da inclusão, contemplando os 4,5 milhões de brasileiros de 15 a 29 anos que não têm ensino fundamental e que estão fora da escola e do mercado de trabalho (Projovem Urbano, s.d.), dessa forma o Programa ampliou o atendimento para jovens entre 18 e 29 anos que saibam ler e escrever.

Em 2012 o Projovem Urbano passou a ser coordenado nacionalmente pelo Ministério da Educação, tendo sua gestão diretamente vinculada às Secretarias Estaduais e/ou Municipais de Educação. Essa transição teria acontecido para garantir a atualização, o aperfeiçoamento e a expansão do programa.

Diante do exposto, esta dissertação irá apresentar um estudo sobre o ProJovem Urbano no Distrito Federal, realizado com egressos ${ }^{8}$ da edição de 2012, tendo como objetivo central de pesquisa verificar de que forma esta política pública contribuiu para que os jovens fossem inseridos no mercado de trabalho do DF.

A dissertação está dividida em quatro capítulos. O primeiro trata da exposição dos Marcos Legais relacionados aos jovens e à juventude. Até há alguns anos não havia legislação

\footnotetext{
${ }^{4} \mathrm{O}$ termo evadidos faz referência aos jovens que embora tivessem sido matriculados, deixaram de freqüentar às aulas.

${ }^{5}$ Um bônus demográfico é possível quando a população em idade ativa torna-se relativamente maior do que a população fora da idade ativa.

${ }^{6}$ São consideradas jovens as pessoas com idade entre 15 (quinze) e 29 (vinte e nove) anos de idade".

7 O Grupo Interministerial foi composto por representantes dos 19 ministérios. O Grupo recomendou a criação da Secretaria Nacional da Juventude (SNJ), do Conselho Nacional de Juventude (Conjuve) e do Programa Nacional de Inclusão de Jovens (Projovem), instituídos em 30 de junho de 2005 pela Lei 11.129 .

${ }^{8} \mathrm{O}$ termo egressos faz referência aos alunos que concluíram o Programa
} 
brasileira específica que tratava/mencionava sobre a juventude. Havia apenas o Estatuto da Criança e do Adolescente - ECA, que não era específico para a juventude. Em 2003, com a Comissão Especial de Políticas Públicas de Juventude houve um avanço institucional da política pública de juventude surgindo iniciativas importantes que começaram a integrar 0 marco legal das políticas de juventude no Brasil. Então este capítulo, traz um histórico sobre a legislação para juventude, mencionando os marcos mais importantes: Constituição Federal, Estatuto da Juventude e o Plano Nacional de Educação - Lei no 13.005 de 25 de junho de 2014.

O segundo capítulo trata de políticas públicas para a juventude. No primeiro momento será mencionado sobre o ciclo das políticas públicas, ou seja, como um tema se torna relevante e entra na agenda pública para se elaborar e implementar uma política pública. No segundo momento, serão abordadas as políticas públicas para a juventude, trazendo um histórico, desde as primeiras políticas até a implementação do Projovem Urbano.

No terceiro capítulo será abordado o Projovem Urbano, a população jovem e o bônus demográfico. Será mencionada a evolução do Programa, desde o original em 2005, até o que está sendo executado atualmente - Projovem Urbano sob a coordenação do Ministério da Educação. Será feita, também, menção sobre a população jovem e o bônus demográfico.

O quarto capítulo trata dos objetivos da pesquisa e dos aspectos metodológicos. objetivo geral da dissertação é analisar de que forma o Projovem Urbano contribuiu para que os jovens, egressos do programa da edição 2012, pudessem ser inseridos no mercado de trabalho. Enquanto que os objetivos específicos são: a) Identificar quantos estudantes, de fato, conseguiram o certificado de conclusão de curso, para a edição de 2012; b) Identificar quais foram os arcos ocupacionais selecionados para serem ofertados aos estudantes do Projovem da edição 2012; c) Verificar se a qualificação profissional recebida no Programa ajudou os jovens a serem inseridos no mercado de trabalho e se os mesmos estão aplicando os conhecimentos adquiridos em sua profissão; e d) Verificar se caso os jovens não tenham conseguido ingressar no mercado de trabalho, qual ou quais foram os motivos.

Para alcançar os objetivos propostos na dissertação foi utilizada a metodologia qualitativa e quantitativa. Os dados quantitativos foram extraídos do SIMEC - Sistema Integrado de Monitoramento Execução e Controle do Ministério da Educação, os dados se referem ao número de matriculados, desistentes e concluintes do Programa. A população alvo foram os 111 jovens concluintes do Programa na edição de 2012 (Em 2012 a meta foi de 800 matrículas, mas foram feitas 462 e efetivadas 354 e apenas 111 estudantes concluíram o Programa, o que é de cerca de $14 \%$ da meta inicial), para a pesquisa foram realizadas 44 entrevistas com os estudantes egressos do Programa, e entrevistas com o gestor local e o gestor nacional do Projovem. As entrevistas com os egressos foram compiladas e constituiu-se um banco de dados que foi, então trabalhado e apresentado em forma de gráficos, já as entrevistas realizadas com os gestores foram degravadas e analisadas. Com os dados coletados, tanto por meio do SIMEC, quanto pelas entrevistas, começou-se a traçar o perfil dos estudantes egressos da edição de 2012, o que permitiu chegar-se às conclusões finais.

Com a elaboração dessa dissertação foi possível verificar que o Projovem no DF 
precisa ter um acompanhamento mais eficaz, isso devido ao fato de que o Programa não consegue atingir as metas propostas e o número de estudantes concluintes é muito baixo. Verificou-se, também, que dos 44 entrevistados - no que se refere à inserção no mercado de trabalho - apenas $18 \%$ afirmaram que houve melhora.

Espera-se que essa dissertação possa contribuir para uma ainda escassa produção de avaliações de programas governamentais, sobretudo em âmbito estadual. 


\section{CAPÍTULO 1: MARCOS LEGAIS PARA A POPULAÇÃO JOVEM}

Nos últimos quinze anos verifica-se que questões como educação, justiça e trabalho vêm sendo reconhecidas pelo poder público e sendo inseridas na agenda social e nas políticas públicas para juventude. Essas questões sempre fizeram parte do desenvolvimento educacional dos jovens, contudo, somente agora estão sendo alvos específicos de políticas, compreendidas como direito, ao qual se devem respostas públicas e democráticas. É possível observar que somente em 2005 é que foi implementada uma política educacional voltada para jovens que abarcasse essas três dimensões, no caso o Projovem.

O Documento-Referência da Conae 2010 menciona que: "Em uma sociedade marcada por profundas desigualdades sociais, de classe, de gênero, étnico-raciais e geracionais, a garantia de uma educação pautada na justiça social, que considere o mundo do trabalho para além da teoria do capital humano e que reconheça a diversidade ampliando a noção de inclusão e igualdade social, constitui um desafio" (Conae 2010, p. 96). menciona que:

Quando se fala de justiça social, o Documento-Referência da Conae 2010

Um Estado democrático que tem como eixo a garantia da justiça social é aquele que reconhece o cidadão como sujeito de direitos, inserido em uma ordem política, econômica, social e cultural, colocando como norte da sua ação política a superação das desigualdades sociais, raciais e de gênero. Em pleno século XXI, no momento em que a luta pelo direito à diferença se consolida nos mais diversos campos, não cabe mais a realização de políticas e práticas pautadas na noção de neutralidade estatal (Conae 2010, p. 99).

Isso nos remete aos ensinamentos de John Rawls com a Teoria da Justiça. Para Rawls (1981 p. 27): "A justiça é a primeira virtude das instituições sociais assim como a verdade é a virtude principal dos sistemas de pensamento".

Rawls propõe princípios e procedimentos a serem adotados pelo Estado na solução de questões relativas às desigualdades entre os homens. A questão central são os direitos do homem a serem alcançados na sociedade, sob a correção da justiça como equidade. (Barros, 2007).

De acordo com Lima e Gonçalves (2013, p. 55) as desigualdades sociais apresentam-se como um problema estrutural relacionada a diversos grupos humanos pertencentes a diversas formas de organização governamental. As autoras mencionam que diante disso surge a premência do Estado como moderador de forças, um interventor que tem a função de garantir o bem estar social e propiciar a redistribuição social. Diante disso é importante trazer as lições de Rawls e de Sen.

Barros (2007) menciona que Rawls traz grande contribuição à teoria política e sua concepção política de justiça como eqüidade não decide se os princípios elaborados por ele se realizam melhor na democracia da propriedade privada ou no regime liberal-socialista. Considerando as circunstâncias particulares de uma nação, Rawls mostra a possibilidade de tais questões serem solucionadas de forma inteligente e racional.

Silva Júnior (2010, p. 2375) explica que o conceito de justiça social é passível de 
várias interpretações:

Através dessa distribuição equitativa de direitos, deveres e funções entre os membros da sociedade, torna-se mais próxima e viável a obtenção de uma ordem social justa. Todavia, o conceito de justiça social é passível de múltiplas deduções interpretativas, pois evolui e se adapta consoante os avanços da própria sociedade, sobretudo, com aquilo que ela mesma julga ou entende como básico, necessário e/ ou fundamental.

Barros (2007) menciona que Rawls trata de dilemas da democracia liberal, ao esboçar todo um itinerário de compreensão do que seja o justo na sociedade humana. Para tanto enfrenta a teleologia, o utilitarismo, o intuicionismo e a deontologia, interpretando-os e os avaliando, para construir o objeto de sua elucidação filosófica, na tentativa de encontrar uma concepção razoável e pública de justiça.

Rawls era um crítico do pensamento utilitarista. Silva Júnior (2010, p. 2378) menciona que:

\begin{abstract}
Rawls indica que assim como no campo individual a maximização do bem-estar de uma pessoa se constrói com a soma de suas satisfações ao longo da vida e em diferentes momentos, com um cálculo de perdas e ganhos, elegendo aquilo que é mais útil e prioritário, a sociedade, no campo coletivo, também obedece à mesma lógica, ou seja, o bem estar de uma sociedade deve ser construído de acordo com o sistema de desejos ou satisfações dos numerosos indivíduos que a compõem. Entende-se, com isso, que a sociedade deveria se comportar com relação aos seus membros do mesmo modo que cada indivíduo se comporta ou com relação a cada um de seus interesses e necessidades particulares. Rawls acusa, portanto, o utilitarismo de considerar como bem ordenada e justa uma sociedade que privasse alguns indivíduos da satisfação de seus interesses em prol da maximização do bem-estar e satisfação da coletividade ou da maioria.
\end{abstract}

Silva Júnior (2010, p. 2378) explica que: "tal indicativo corrobora as críticas de impossibilidade da doutrina utilitarista como meio de obtenção de justiça social, ao passo que, levando-se em consideração a multiplicidade de sentimentos individuais, não há como se criar um sistema homogêneo de desejo social".

Barros (2007) explica que a intenção de Rawls é elaborar uma teoria da justiça onde se possa interpretar e avaliar proposições que se tornaram convicções ao longo da tradição da filosofia política. Uma teoria não deve ser aceita se não é verdadeira, tanto quanto leis e instituições precisam ser modificadas ou extintas se são injustas.

Kang (2011) menciona que: "para Rawls existem certos bem primários que todo indivíduo racional deseja, uma vez que esses bens primários são meios necessários para atingir esses objetivos, quaisquer que sejam eles".

Entre os bens primários de Rawls pode-se destacar alguns como: "direitos e liberdades fundamentais", "liberdade de movimento e livre escolha de ocupação em um contexto de oportunidades diversificadas", "poderes e prerrogativas de cargos e posições de responsabilidade nas instituições políticas e econômicas da estrutura básica", "renda e riqueza", e "as bases sociais do autorrespeito". Kang (2011) 
Para as autoras Lima e Gonçalves (2013) é importante trazer à reflexão a construção de uma sociedade que proporcione a todos, sem distinção, uma situação de equidade, de acesso aos meios e recursos sociais como educação, saúde, lazer e promova a extensão das capacidades humanas como meio para inclusão dos sujeitos excluídos e a melhoria da situação econômica como conseqüência. Dessa forma o desenvolvimento deve estar baseado em prerrogativas que proporcionem a expansão das capacidades humanas. Ao estudar o Projovem Urbano, é importante compreender a juventude em seu contexto sóciohistórico, cultural, econômico e geográfico pois essas dimensões articulam-se de forma a construir um determinado modo de ser jovem.

Silva Júnior (2010, p. 2381) explica que mesmo com os avanços ideológicos estabelecidos pela doutrina de Rawls, no que se refere à proteção social como instrumento de justiça social, existiam algumas lacunas que precisavam de reparo para que se justificasse melhor a necessidade de um amparo social efetivo por parte do Estado. Explica o autor que:

\begin{abstract}
É evidente que uma proteção socialmente eficaz precisaria levar em conta critérios que não foram analisados pela corrente rawlsiana, a exemplo das supracitadas desigualdades naturais que, por conseguinte, tornam os indivíduos díspares em capacidade para usufruírem dos seus direitos e liberdades. Neste aspecto, o economista indiano Amatya Sen trouxe outras inovações ao pensamento sócio jurídico da justiça social e, obviamente, da proteção social, ao passo que atribui uma nova compreensão aos conceitos sobre miséria, fome, pobreza e bem-estar social.
\end{abstract}

Sen menciona sobre a importância de se verificar o alcance da liberdade individual em certo contexto, separando as condições sociais das de agente individual. Isso se refere ao fato de se analisar as condições particulares de cada indivíduo para o exercício de suas escolhas, para a obtenção de uma efetiva igualdade entre os membros da sociedade. Para Sen, a justiça social deve estar diretamente ligada à liberdade e à capacidade que cada indivíduo tem para exercê-la.

Visto que a sociedade brasileira é marcada por profundas desigualdades sociais, de classe, de gênero, étnico-raciais e geracionais, a garantia de uma educação pautada na justiça social, que considere o mundo do trabalho para além da teoria do capital humano, que reconheça a diversidade ampliando a noção de inclusão e igualdade social, trata-se de um grande desafio.

De acordo com Mesquita (2009, p.7) os pressupostos que orientam o Projovem Urbano dão valor a formação de capital humano, partindo do conceito de que o conceito de trabalho humano, quando qualificado por meio da educação, é um importante mecanismo para a criação da produtividade. A educação pode ser um importante instrumento da emancipação humana.

Mészaros (2004) destaca a ideia de que as reformas educacionais não acarretam mudanças significativas na sociedade capitalista, pois o seu sistema não admite controle. Tendo em vista o caráter incorrigível do capital, o autor menciona que essas reformas geralmente fracassam, todavia, isso não significa que nenhuma modificação superficial seja possível, pois algumas são até desejáveis a fim de amenizar as conseqüências dos defeitos 
estruturais desse sistema, permitindo a sua incessante reprodução.

Mészáros (2004, p. 201) explica que:

O impacto da lógica incorrigível do capital sobre a educação tem sido grande ao longo do desenvolvimento do sistema. [...] É por isso que hoje o significado da mudança educacional radical não pode ser senão o rasgar do colete-de-forças da lógica incorrigível do sistema: através do planeamento e da prossecução consistente da estratégia de quebrar a regra do capital com todos os meios disponíveis, assim como com todos aqueles que ainda têm de ser inventados neste espírito.

Para o autor, para se ter educação significativamente diferente é preciso romper com a lógica do capital. Mészáros (2004) entende que a escola reforça a internalização do modo de sistema social capitalista, contribuindo para impedir a transformação do entendimento dominante. $\mathrm{O}$ autor critica a educação formal, posto que esta reproduz o capitalismo.

Para Mészáros (2004) a educação das escolas somente pode se tornar significativa na formação de outra sociedade e nesta formação a educação tem que estar associada em sentido amplo, ou seja, associada à vida. E nesta formação de outra sociedade a lógica do capital tem que estar superada. Para o autor não se trata apenas de uma "mudança educacional", mas sim de uma mudança objetiva de toda a forma de vida, de todo o modo de ser da humanidade na produção/reprodução de sua existência, de maneira que a educação deixe de ser um momento específico da vida, com fins utilitários determinados, e passe a ser a própria vida de todos os homens.

Com relação ao trabalho, o Documento-final da Conae (2014, p. 51) menciona que:

A educação é uma prática social cada vez mais ampla e presente na sociedade contemporânea, pois vêm se multiplicando os ambientes e processos de aprendizagem formais e informais, envolvendo práticas pedagógicas e formativas em instituições educativas, no trabalho, nas mídias, nos espaços de organização coletiva, potencializados pelas tecnologias de comunicação e informação. Isso se vincula às novas exigências e demandas do mundo do trabalho e da produção, assim como ao desenvolvimento científico e tecnológico, aos aspectos de constituição da cultura local, regional, nacional e internacional e à problemática ambiental e da saúde pública no País.

Em virtude das transformações econômicas e políticas no contexto internacional e no Brasil, que se apresentaram desde os anos 1980, consequência da reestruturação produtiva, da mundialização (globalização) do capital e da revolução tecnológica, implicam processos de regulação que ocasionam mudanças no papel e na forma de atuação do Estado, bem como nas políticas educacionais, que passaram a se orientar, cada vez mais, pela lógica do mercado e da competição (Documento-Referência da Conae 2014, p. 51).

Diante disso o que se verifica é que esse modo de regulação se contrapõe a ideia de um Estado democrático de direito, no qual o trabalho, a educação, a cultura, a ciência e a tecnologia formariam fatores de desenvolvimento econômico e social, inclusão, melhoria da qualidade de vida, desenvolvimento sustentável, requisitos para a superação dos mecanismos que historicamente, mantêm as desigualdades. (Documento-Referência da Conae 2014, p. 51) 


\subsection{Constituição Federal}

Nesse primeiro capítulo, a fim de situar o leitor a respeito da inclusão dos jovens nos marcos legais, e de detalhar a forma pela qual houve o fortalecimento institucional da política pública para a juventude e como, gradualmente, teve-se a idéia e a criação do ProJovem, será feito um breve retrospecto sobre a evolução de aspectos legais de programas voltados para a juventude com partes específicas da Constituição Federal, de Leis, Projetos, Decretos, e estatutos referentes à juventude.

É importante mencionar que até a alguns anos não havia menção da juventude na legislação brasileira, aliás, a que chegava mais próximo era o Estatuto da Criança e do Adolescente - ECA, contudo não era específico para a juventude. A partir de 2003, com a Comissão Especial de Políticas Públicas de Juventude houve um fortalecimento institucional da política pública de juventude surgindo iniciativas relevantes e que fazem parte do que está sendo denominado de marco legal das políticas de juventude no Brasil.

Inicialmente tem-se a Emenda Constitucional ํㅜ 65, promulgada em 13 de julho de 2010, que altera a denominação do Capítulo VII do Título VIII da Constituição Federal (CF) e modifica o seu art. 227, para cuidar dos interesses da juventude, incluindo o termo jovem na CF, assegurando aos jovens de 15 a 29 anos prioridade no acesso a direitos constitucionais como saúde, alimentação, educação, lazer, profissionalização e cultura, que já eram, então, garantidos às crianças, adolescentes e idosos.

No inciso II, parágrafo $1^{\circ}$ do artigo 227, da CF, é mencionado que: O Estado promoverá programas de assistência integral à saúde da criança, do adolescente e do jovem, admitida a participação de entidades não governamentais, mediante políticas específicas e obedecendo aos seguintes preceitos:

II - criação de programas de prevenção e atendimento especializado para as pessoas portadoras de deficiência física, sensorial ou mental, bem como de integração social do adolescente e do jovem portador de deficiência, mediante 0 treinamento para 0 trabalho e a convivência, e a facilitação do acesso aos bens e serviços coletivos, com a eliminação de obstáculos arquitetônicos e de todas as formas de discriminação.

$\S 3^{\circ}(\ldots)$

III - garantia de acesso do trabalhador adolescente e jovem à escola;

VII - programas de prevenção e atendimento especializado à criança, ao adolescente e ao jovem dependente de entorpecentes e drogas afins.

$\S 8^{\circ}$ A lei estabelecerá:

I - o estatuto da juventude, destinado a regular os direitos dos jovens; II - o plano nacional de juventude, de duração decenal, visando à articulação das várias esferas do poder público para a execução de políticas públicas. (NR)

\subsection{Estatuto da Juventude}

Uma das primeiras mobilizações voltadas a atender as necessidades especificas dos jovens foi a instituição do Estatuto da Juventude, como mencionado acima, o qual se deu por meio do Projeto de Lei o 4530/04, que tramitou por quase dez anos pelo Congresso Nacional, sendo aprovado em julho de 2013 e sancionado pela presidenta Dilma Rousseff em 
agosto do mesmo ano. O projeto se transformou na Lei № 12.852, de 5 de agosto de 2013 e foi um importante passo para a população jovem, visto que dispõe sobre os direitos dos jovens, os princípios e diretrizes das políticas públicas de juventude e o Sistema Nacional de Juventude SINAJUVE.

O Estatuto da Juventude é um o instrumento legal que determina quais são os direitos dos jovens que devem ser garantidos e promovidos pelo Estado brasileiro. Ao todo são 11 direitos previstos no Estatuto.

A seguir será feita uma apresentação do Estatuto da Juventude com os comentários da Secretaria Nacional da Juventude, com a intenção de mostrar como o tema Juventude vem ganhando importância na agenda.

A Lei trouxe a definição legal de população jovem, (o que veio a alterar, posteriormente, o Projovem), em seu artigo 1ㅇ, $\S 1^{\circ}$ : "Para os efeitos desta Lei, são consideradas jovens as pessoas com idade entre 15 (quinze) e 29 (vinte e nove) anos de idade

O Estatuto traz, em seu artigo 2º, os princípios pelos quais as políticas públicas deverão ser regidas:

I - promoção da autonomia e emancipação dos jovens ${ }^{9}$;

II - valorização e promoção da participação social e política, de forma direta e por meio de suas representações;

III - promoção da criatividade e da participação no desenvolvimento do País;

IV - reconhecimento do jovem como sujeito de direitos universais, geracionais e singulares;

V - promoção do bem-estar, da experimentação e do desenvolvimento integral do jovem;

VI - respeito à identidade e à diversidade individual e coletiva da juventude;

VII - promoção da vida segura, da cultura da paz, da solidariedade e da não discriminação; e

VIII - valorização do diálogo e convívio do jovem com as demais gerações.

A Seção II, artigo $3^{\circ}$ do Estatuto trata das diretrizes gerais e menciona que:

Art. 3o Os agentes públicos ou privados envolvidos com políticas públicas de juventude devem observar as seguintes diretrizes:

I - desenvolver a intersetorialidade das políticas estruturais, programas e ações;

II - incentivar a ampla participação juvenil em sua formulação, implementação e avaliação;

III - ampliar as alternativas de inserção social do jovem, promovendo programas que priorizem 0 seu desenvolvimento integral $e$ participação ativa nos espaços decisórios;

IV - proporcionar atendimento de acordo com suas especificidades perante os órgãos públicos e privados prestadores de serviços à população, visando ao gozo de direitos simultaneamente nos campos da saúde, educacional, político, econômico, social, cultural e ambiental;

${ }^{9}$ Com relação ao inciso I, o Estatuto menciona que a emancipação dos jovens refere-se à trajetória de inclusão, liberdade e participação do jovem na vida em sociedade, e não ao instituto da emancipação disciplinado pela Lei $n^{\circ}$ 10.406, de 10 de janeiro de 2002 - Código Civil. 
$V$ - garantir meios e equipamentos públicos que promovam o acesso à produção cultural, à prática esportiva, à mobilidade territorial e à fruição do tempo livre;

VI - promover o território como espaço de integração;

VII - fortalecer as relações institucionais com os entes federados e as redes de órgãos, gestores e conselhos de juventude;

VIII - estabelecer mecanismos que ampliem a gestão de informação e produção de conhecimento sobre juventude;

IX - promover a integração internacional entre os jovens, preferencialmente no âmbito da América Latina e da África, e a cooperação internacional;

$\mathrm{X}$ - garantir a integração das políticas de juventude com os Poderes Legislativo e Judiciário, com o Ministério Público e com a Defensoria Pública; e

$\mathrm{XI}$ - zelar pelos direitos dos jovens com idade entre 18 (dezoito) e 29 (vinte e nove) anos privados de liberdade e egressos do sistema prisional, formulando políticas de educação e trabalho, incluindo estímulos à sua reinserção social e laboral, bem como criando e estimulando oportunidades de estudo e trabalho que favoreçam o cumprimento do regime semiaberto.

A partir do Capítulo II começam os direitos dos jovens previstos no Estatuto e o primeiro é do Direito à Cidadania, à Participação Social e Política e à Representação Juvenil, no artigo 4ํㅡㄹ menciona que: "O jovem tem direito à participação social e política e na formulação, execução e avaliação das políticas públicas de juventude".

Participação juvenil, para o Estatuto, é:

I - a inclusão do jovem nos espaços públicos e comunitários a partir da sua concepção como pessoa ativa, livre, responsável e digna de ocupar uma posição central nos processos políticos e sociais;

II - o envolvimento ativo dos jovens em ações de políticas públicas que tenham por objetivo o próprio benefício, o de suas comunidades, cidades e regiões e o do País;

III - a participação individual e coletiva do jovem em ações que contemplem a defesa dos direitos da juventude ou de temas afetos aos jovens; e

IV - a efetiva inclusão dos jovens nos espaços públicos de decisão com direito a voz e voto.

No Art. 5o o estatuto trata de como pode ser feita a interlocução da juventude com o poder público, que pode se realizar por intermédio de associações, redes, movimentos e organizações juvenis. Sendo dever do poder público incentivar a livre associação dos jovens.

E no Art. 6ำ trata das diretrizes da interlocução institucional juvenil: "I - a definição de órgão governamental específico para a gestão das políticas públicas de juventude; II - o incentivo à criação de conselhos de juventude em todos os entes da Federação". Trata ainda o Parágrafo único:

Sem prejuízo das atribuições do órgão governamental específico para a gestão das políticas públicas de juventude e dos conselhos de juventude com relação aos direitos previstos neste Estatuto, cabe ao órgão governamental de gestão e aos conselhos dos direitos da criança e do adolescente a interlocução institucional com adolescentes de idade entre 15 (quinze) e 18 (dezoito) anos.

De acordo com a Secretaria Nacional de Juventude (s.d) a participação juvenil nos espaços públicos é entendida a partir da inclusão dos jovens como pessoas ativas, livres, 
responsáveis e dignas de ocupar uma posição central nos processos políticos e sociais. A participação dos jovens pode ser individual e coletiva, tendo por objetivo o próprio benefício, de suas comunidades, cidades, regiões e do País. A interlocução da juventude com o poder público é realizada por meio de redes, associações, movimentos e organizações juvenis. É dever dos governos incentivar a livre associação dos jovens e a sua inclusão efetiva nos espaços de decisão com direito à voz e voto ${ }^{10}$.

O segundo direito previsto no Estatuto é o Direito à Educação. A Constituição Federal de 1988, no Art. 205 menciona que: "A educação, direito de todos e dever do Estado e da família, será promovida e incentivada com a colaboração da sociedade, visando ao pleno desenvolvimento da pessoa, seu preparo para o exercício da cidadania e sua qualificação para o trabalho".

No Art. 70 menciona que: "O jovem tem direito à educação de qualidade, com a garantia de educação básica, obrigatória e gratuita, inclusive para os que a ela não tiveram acesso na idade adequada". E nos parágrafos seguintes contempla os jovens e sua diversidade:

§ 1o A educação básica será ministrada em língua portuguesa, assegurada aos jovens indígenas e de povos e comunidades tradicionais a utilização de suas línguas maternas e de processos próprios de aprendizagem.

$\S 2$ É dever do Estado oferecer aos jovens que não concluíram a educação básica programas na modalidade da educação de jovens e adultos, adaptados às necessidades e especificidades da juventude, inclusive no período noturno, ressalvada a legislação educacional específica.

§ 3o São assegurados aos jovens com surdez o uso e o ensino da Língua Brasileira de Sinais - LIBRAS, em todas as etapas e modalidades educacionais.

$\S 40$ É assegurada aos jovens com deficiência a inclusão no ensino regular em todos os níveis e modalidades educacionais, incluindo o atendimento educacional especializado, observada a acessibilidade a edificações, transportes, espaços, mobiliários, equipamentos, sistemas e meios de comunicação e assegurados os recursos de tecnologia assistiva e adaptações necessárias a cada pessoa.

§ 5o A Política Nacional de Educação no Campo contemplará a ampliação da oferta de educação para os jovens do campo, em todos os níveis e modalidades educacionais.

Este Capítulo também menciona sobre o direito à educação superior, em seu Art. 8o diz que o jovem tem direito à educação superior, em instituições públicas ou privadas, com variados graus de abrangência do saber ou especialização do conhecimento, observadas as regras de acesso de cada instituição ${ }^{11}$. E os parágrafos tratam de políticas afirmativas ${ }^{12}$, como as cotas e sobre o financiamento estudantil e bolsas de estudos:

10 Disponível em: http://www.juventude.gov.br/guia/principais-programas-dejuventude/programa-nacional-de-inclusao-de-jovens-projovem. Acesso em out. 2012

${ }^{11} \S 1^{\circ}$ É assegurado aos jovens negros, indígenas e estudantes oriundos da escola pública o acesso ao ensino superior nas instituições públicas por meio de políticas afirmativas, nos termos da lei. 
O Art. 9o trata do direito à educação profissional e tecnológica, articulada com os diferentes níveis e modalidades de educação, ao trabalho, à ciência e à tecnologia, observada a legislação vigente.

O Art. 10 menciona sobre o dever do Estado de assegurar ao jovem com deficiência o atendimento educacional especializado gratuito, preferencialmente, na rede regular de ensino.

O Art. 11 trata do direito ao programa suplementar de transporte escolar de que trata 0 art. $4^{\circ}$ da Lei $n^{\circ} 9.394$, de 20 de dezembro de 1996, será progressivamente estendido ao jovem estudante do ensino fundamental, do ensino médio e da educação superior, no campo e na cidade.

O Art. 12 menciona sobre a garantia de participação efetiva do segmento juvenil, respeitada sua liberdade de organização, nos conselhos e instâncias deliberativas de gestão democrática das escolas e universidades.

O Art. 13 diz que as escolas e as universidades deverão formular e implantar medidas de democratização do acesso e permanência, inclusive programas de assistência estudantil, ação afirmativa e inclusão social para os jovens estudantes.

A Secretaria Nacional da Juventude $(\mathrm{s} / \mathrm{d})$ menciona que todo jovem tem direito à educação de qualidade, em todos os seus níveis, adaptando-se às necessidades e especificidades da juventude, inclusive no período noturno. Esse é um direito garantido pelo Estatuto da Juventude. A educação básica é obrigatória e deve ser oferecida gratuitamente a todos, inclusive para aqueles que não tiveram acesso na idade adequada ${ }^{13}$.

O Estatuto aponta para a importância das políticas afirmativas e da expansão: da educação superior nas instituições públicas, do financiamento e da assistência estudantil, das bolsas de estudos e do transporte escolar. O Estatuto destaca, ainda as necessidades dos jovens negros, do campo, indígenas e com deficiência, e diz que deve ser garantida a liberdade de organização dos estudantes e a sua participação efetiva para a gestão democrática das escolas e universidades. (Secretaria Nacional da Juventude, s/d).

A Seção III trata do Direito à Profissionalização, ao Trabalho e à Renda. No Art. 14 menciona que o jovem tem direito à profissionalização, ao trabalho e à renda, exercido em condições de liberdade, equidade e segurança, adequadamente remunerado e com proteção social.

$\S 2^{\circ}$ O poder público promoverá programas de expansão da oferta de educação superior nas instituições públicas, de financiamento estudantil e de bolsas de estudos nas instituições privadas, em especial para jovens com deficiência, negros, indígenas e estudantes oriundos da escola pública.

${ }^{12}$ Celso Antônio Bandeira (2003) define que as ações afirmativas: [...] são medidas temporárias e especiais, tomadas ou determinadas pelo Estado, de forma compulsória ou espontânea, com o propósito específico de eliminar as desigualdades que foram acumuladas no decorrer da história da sociedade.

13 Disponível no site: http://www.juventude.gov.br/guia/principais-programas-dejuventude/programa-nacional-de-inclusao-de-jovens-projovem. Acesso em out. 2012. 
E no Art. 15 trata da ação do poder público para a efetivação do direito do jovem à profissionalização, ao trabalho e à renda e contempla a adoção das seguintes medidas:

I - promoção de formas coletivas de organização para o trabalho, de redes de economia solidária e da livre associação;

II - oferta de condições especiais de jornada de trabalho por meio de:

a) compatibilização entre os horários de trabalho e de estudo;

b) oferta dos níveis, formas e modalidades de ensino em horários que permitam a compatibilização da frequência escolar com 0 trabalho regular;

III - criação de linha de crédito especial destinada aos jovens empreendedores;

IV - atuação estatal preventiva e repressiva quanto à exploração e precarização do trabalho juvenil;

V - adoção de políticas públicas voltadas para a promoção do estágio, aprendizagem e trabalho para a juventude;

VI - apoio ao jovem trabalhador rural na organização da produção da agricultura familiar e dos empreendimentos familiares rurais, por meio das seguintes ações:

a) estímulo à produção e à diversificação de produtos;

b) fomento à produção sustentável baseada na agroecologia, nas agroindústrias familiares, na integração entre lavoura, pecuária e floresta e no extrativismo sustentável;

c) investimento em pesquisa de tecnologias apropriadas à agricultura familiar e aos empreendimentos familiares rurais;

d) estímulo à comercialização direta da produção da agricultura familiar, aos empreendimentos familiares rurais e à formação de cooperativas;

e) garantia de projetos de infraestrutura básica de acesso e escoamento de produção, priorizando a melhoria das estradas e do transporte;

f) promoção de programas que favoreçam o acesso ao crédito, à terra e à assistência técnica rural;

VII - apoio ao jovem trabalhador com deficiência, por meio das seguintes ações:

a) estímulo à formação e à qualificação profissional em ambiente inclusivo;

b) oferta de condições especiais de jornada de trabalho;

c) estímulo à inserção no mercado de trabalho por meio da condição de aprendiz.

Quanto ao direito à profissionalização, o Art. 16 menciona, especificamente que a proteção ao trabalho dos adolescentes com idade entre 15 (quinze) e 18 (dezoito) anos de idade será regido pelo disposto na Lei no 8.069, de 13 de julho de 1990 - Estatuto da Criança e do Adolescente, e em leis específicas.

De acordo com a Secretaria Nacional de Juventude (s.d), tal direito garante que todo jovem possa ter acesso à profissionalização, ao trabalho e à renda, em condições de liberdade, equidade e segurança, adequadamente remunerado e com proteção social. Prevê também a promoção de formas coletivas de organização para o trabalho, de redes de economia solidária e da livre associação. Dada às condições especiais de jornada de trabalho, o Estatuto prevê a compatibilização entre horários de trabalho e de estudo. O Estatuto prevê também incentivos ao jovem trabalhador rural em sua organização na produção da agricultura 
familiar e dos empreendimentos familiares rurais. A formação e a qualificação profissional também devem estar garantidas aos jovens com deficiência ${ }^{14}$.

A Seção IV, trata do Direito à Diversidade e à Igualdade. No Art. 17, o Estatuto menciona que o jovem tem direito à diversidade e à igualdade de direitos e de oportunidades $\mathrm{e}$ não será discriminado por motivo de:I - etnia, raça, cor da pele, cultura, origem, idade e sexo; II - orientação sexual, idioma ou religião; III - opinião, deficiência e condição social ou econômica.

No Art. 18, o Estatudo afirma que a ação do poder público na efetivação do direito do jovem à diversidade e à igualdade deve contemplar a adoção das seguintes medidas:

I - adoção, nos âmbitos federal, estadual, municipal e do Distrito Federal, de programas governamentais destinados a assegurar a igualdade de direitos aos jovens de todas as raças e etnias, independentemente de sua origem, relativamente à educação, à profissionalização, ao trabalho e renda, à cultura, à saúde, à segurança, à cidadania e ao acesso à justiça;

II - capacitação dos professores dos ensinos fundamental e médio para a aplicação das diretrizes curriculares nacionais no que se refere ao enfrentamento de todas as formas de discriminação;

III - inclusão de temas sobre questões étnicas, raciais, de deficiência, de orientação sexual, de gênero e de violência doméstica e sexual praticada contra a mulher na formação dos profissionais de educação, de saúde e de segurança pública e dos operadores do direito;

IV - observância das diretrizes curriculares para a educação indígena como forma de preservação dessa cultura;

V - inclusão, nos conteúdos curriculares, de informações sobre a discriminação na sociedade brasileira e sobre o direito de todos os grupos e indivíduos a tratamento igualitário perante a lei; e

VI - inclusão, nos conteúdos curriculares, de temas relacionados à sexualidade, respeitando a diversidade de valores e crenças.

A Secretaria Nacional de Juventude (s.d ${ }^{15}$ menciona que:

Ter direito à Diversidade e à Igualdade significa garantir que o jovem não seja discriminado por sua etnia, raça, cor da pele, cultura, origem, idade, orientação sexual, idioma, religião, opinião, condição social ou econômica. Cabe ao poder público assegurar a igualdade de direitos entre todos os jovens no acesso à educação, saúde, segurança, cidadania e justiça.

Para isso, o direito à Diversidade e à Igualdade aponta a necessidade de capacitar profissionais da educação, da saúde e da segurança pública para enfrentar qualquer forma de discriminação em seus ambientes de trabalho. A meta é que todos os jovens da sociedade brasileira recebam tratamento igualitário, independentemente de sua diversidade.

A Seção V trata do Direito à Saúde, no Art. 19 é dito que jovem tem direito à saúde e à qualidade de vida, considerando suas especificidades na dimensão da prevenção, promoção, proteção e recuperação da saúde de forma integral.

\footnotetext{
14 Ibidem

15 Ibidem
} 
No Art. 20 diz que a política pública de atenção à saúde do jovem será desenvolvida em consonância com as seguintes diretrizes:

I - acesso universal e gratuito ao Sistema Único de Saúde - SUS e a serviços de saúde humanizados e de qualidade, que respeitem as especificidades do jovem;

II - atenção integral à saúde, com especial ênfase ao atendimento e à prevenção dos agravos mais prevalentes nos jovens;

III - desenvolvimento de ações articuladas entre os serviços de saúde e os estabelecimentos de ensino, a sociedade e a família, com vistas à prevenção de agravos;

IV - garantia da inclusão de temas relativos ao consumo de álcool, tabaco e outras drogas, à saúde sexual e reprodutiva, com enfoque de gênero e dos direitos sexuais e reprodutivos nos projetos pedagógicos dos diversos níveis de ensino;

V - reconhecimento do impacto da gravidez planejada ou não, sob os aspectos médico, psicológico, social e econômico;

VI - capacitação dos profissionais de saúde, em uma perspectiva multiprofissional, para lidar com temas relativos à saúde sexual e reprodutiva dos jovens, inclusive com deficiência, e ao abuso de álcool, tabaco e outras drogas pelos jovens;

VII - habilitação dos professores e profissionais de saúde e de assistência social para a identificação dos problemas relacionados ao uso abusivo e à dependência de álcool, tabaco e outras drogas e o devido encaminhamento aos serviços assistenciais e de saúde;

VIII - valorização das parcerias com instituições da sociedade civil na abordagem das questões de prevenção, tratamento e reinserção social dos usuários e dependentes de álcool, tabaco e outras drogas; IX - proibição de propagandas de bebidas contendo qualquer teor alcoólico com a participação de pessoa com menos de 18 (dezoito) anos de idade;

$X$ - veiculação de campanhas educativas relativas ao álcool, ao tabaco e a outras drogas como causadores de dependência; e

XI - articulação das instâncias de saúde e justiça na prevenção do uso e abuso de álcool, tabaco e outras drogas, inclusive esteróides anabolizantes e, especialmente, crack.

A Secretaria Nacional da Juventude (s.d ${ }^{16}$ menciona que:

Isso significa que o poder público tem que garantir aos jovens o acesso aos serviços públicos de saúde de maneira integral e com qualidade. Considerando as especificidades da faixa etária compreendida entre 15 e 29 anos, os atendimentos devem ser humanizados, com trabalho de prevenção aos problemas que são mais presentes entre a juventude.

O direito à Saúde também visa à capacitação de profissionais da área, professores e assistentes sociais no trato com temas e situações relativas à saúde sexual, uso de álcool, tabaco e outras drogas como esteroides, anabolizantes e, especialmente, o crack. Os governos também devem estabelecer parcerias com instituições da sociedade civil que trabalhem com essas questões.

$\mathrm{Na}$ Seção VI, o Estatuto trata do Direito à Cultura, no Art. 21 menciona que o jovem tem direito à cultura, incluindo a livre criação, o acesso aos bens e serviços culturais e a participação nas decisões de política cultural, à identidade e diversidade cultural e à memória social.

${ }^{16}$ Ibidem 
O Art. 22 fala que na consecução dos direitos culturais da juventude, compete ao poder público:

I - garantir ao jovem a participação no processo de produção, reelaboração e fruição dos bens culturais;

II - propiciar ao jovem o acesso aos locais e eventos culturais, mediante preços reduzidos, em âmbito nacional;

III - incentivar os movimentos de jovens a desenvolver atividades artístico-culturais e ações voltadas à preservação do patrimônio histórico;

IV - valorizar a capacidade criativa do jovem, mediante o desenvolvimento de programas e projetos culturais;

$\mathrm{V}$ - propiciar ao jovem o conhecimento da diversidade cultural, regional e étnica do País;

VI - promover programas educativos e culturais voltados para a problemática do jovem nas emissoras de rádio e televisão e nos demais meios de comunicação de massa;

VII - promover a inclusão digital dos jovens, por meio do acesso às novas tecnologias da informação e comunicação;

VIII - assegurar ao jovem do campo o direito à produção e à fruição cultural $\mathrm{e}$ aos equipamentos públicos que valorizem a cultura camponesa; e

IX - garantir ao jovem com deficiência acessibilidade e adaptações razoáveis.

Parágrafo único. A aplicação dos incisos I, III e VIII do caput deve observar a legislação específica sobre o direito à profissionalização $\mathrm{e}$ à proteção no trabalho dos adolescentes.

O Art. 23 e parágrafos assegura aos jovens de até 29 (vinte e nove) anos pertencentes a famílias de baixa renda e aos estudantes, na forma do regulamento, o acesso a salas de cinema, cineclubes, teatros, espetáculos musicais e circenses, eventos educativos, esportivos, de lazer e entretenimento, em todo o território nacional, promovidos por quaisquer entidades e realizados em estabelecimentos públicos ou particulares, mediante pagamento da metade do preço do ingresso cobrado do público em geral.

$\S 1$ 1o Terão direito ao benefício previsto no caput os estudantes regularmente matriculados nos níveis e modalidades de educação e ensino previstos no Título $V$ da Lei $n^{\circ}-9.394$, de 20 de dezembro de 1996 - Lei de Diretrizes e Bases da Educação Nacional, que comprovem sua condição de discente, mediante apresentação, no momento da aquisição do ingresso e na portaria do local de realização do evento, da Carteira de Identificação Estudantil - CIE.

$\S 2$ ㅇ A CIE será expedida preferencialmente pela Associação Nacional de Pós-Graduandos, pela União Nacional dos Estudantes, pela União Brasileira dos Estudantes Secundaristas e por entidades estudantis estaduais e municipais a elas filiadas.

§ 3o É garantida a gratuidade na expedição da CIE para estudantes pertencentes a famílias de baixa renda, nos termos do regulamento.

$\S 4$ - As entidades mencionadas no § 20 deste artigo deverão tornar disponível, para eventuais consultas pelo poder público e pelos estabelecimentos referidos no caput, banco de dados com o nome e o número de registro dos estudantes portadores da Carteira de Identificação Estudantil, expedida nos termos do § 3ㅇ deste artigo.

§ 5o A CIE terá validade até o dia 31 de março do ano subsequente à data de sua expedição.

$\S 60$ As entidades mencionadas no $\S 2$ o deste artigo são obrigadas a manter o documento comprobatório do vínculo do estudante com o 
estabelecimento escolar, pelo mesmo prazo de validade da respectiva Carteira de Identificação Estudantil.

§ 7 ㅇ Caberá aos órgãos públicos competentes federais, estaduais, municipais e do Distrito Federal a fiscalização do cumprimento do disposto neste artigo e a aplicação das sanções cabíveis, nos termos do regulamento.

§ 8o Os benefícios previstos neste artigo não incidirão sobre os eventos esportivos de que tratam as Leis $n^{\text {os }} 12.663$, de 5 de junho de 2012, e 12.780, de 9 de janeiro de 2013.

$\S 9$ 9o Considera-se de baixa renda, para os fins do disposto no caput, a família inscrita no Cadastro Único para Programas Sociais do Governo Federal - CadÚnico cuja renda mensal seja de até 2 (dois) salários mínimos.

$\S 10$. A concessão do benefício da meia-entrada de que trata o caput é limitada a $40 \%$ (quarenta por cento) do total de ingressos disponíveis para cada evento.

O Art. 24 trata dos recursos para os projetos culturais, mencionando que o poder público destinará, no âmbito dos respectivos orçamentos, recursos financeiros para o fomento dos projetos culturais destinados aos jovens e por eles produzidos.

O Art. 25 fala da destinação dos recursos do Fundo Nacional da Cultura - FNC, que trata a Lei $\mathrm{n}^{\circ} 8.313$, de 23 de dezembro de 1991, onde serão consideradas as necessidades específicas dos jovens em relação à ampliação do acesso à cultura e à melhoria das condições para o exercício do protagonismo no campo da produção cultural. Menciona em seu parágrafo único que as pessoas físicas ou jurídicas poderão optar pela aplicação de parcelas do imposto sobre a renda a título de doações ou patrocínios, de que trata a Lei no 8.313 , de 23 de dezembro de 1991, no apoio a projetos culturais apresentados por entidades juvenis legalmente constituídas há, pelo menos, 1 (um) ano.

A Seção VII trata do Direito à Comunicação e à Liberdade de Expressão, no Art. 26 menciona que jovem tem direito à comunicação e à livre expressão, à produção de conteúdo, individual e colaborativo, e ao acesso às tecnologias de informação e comunicação.

No Art. 27 é mencionada a ação do poder público na efetivação do direito do jovem à comunicação e à liberdade de expressão contempla a adoção das seguintes medidas:

I - incentivar programas educativos e culturais voltados para os jovens nas emissoras de rádio e televisão e nos demais meios de comunicação de massa;

II - promover a inclusão digital dos jovens, por meio do acesso às novas tecnologias de informação e comunicação;

III - promover as redes e plataformas de comunicação dos jovens, considerando a acessibilidade para os jovens com deficiência;

IV - incentivar a criação e manutenção de equipamentos públicos voltados para a promoção do direito do jovem à comunicação; e

$\mathrm{V}$ - garantir a acessibilidade à comunicação por meio de tecnologias assistivas e adaptações razoáveis para os jovens com deficiência.

Para a Secretaria Nacional de Juventude (s.d) ${ }^{17}$ :

Juventude também é sinônimo de criatividade. Cabe então ao poder público valorizar os coletivos de jovens no desenvolvimento de atividades artístico-culturais diversas. Além disso, é de suma importância que todos os jovens possam fruir em plenitude os bens e

${ }^{17}$ Ibidem 
serviços de cultura em todo o país. Portanto, a meia-entrada cultural é um direito garantido a todos os estudantes e jovens de baixa renda, mesmo que não estejam matriculados em instituições de ensino. Ou seja, espetáculos de teatro e circo, shows, salas de cinema, eventos educativos, esportivos, de lazer e entretenimento têm obrigação de destinar $40 \%$ dos ingressos disponíveis a todos os jovens estudantes ou não - seja o evento realizado por instituições públicas ou particulares. A fiscalização fica por conta do poder público.

O Estatuto cuidou, ainda, do Direito ao Desporto e ao Lazer, na Seção VIII em seu Art. 28 diz que o jovem tem direito à prática desportiva destinada a seu pleno desenvolvimento, com prioridade para o desporto de participação. $O$ direito à prática desportiva dos adolescentes deverá considerar sua condição peculiar de pessoa em desenvolvimento, e no art. 29 menciona que a política pública de desporto e lazer destinada ao jovem deverá considerar:

I - a realização de diagnóstico e estudos estatísticos oficiais acerca da educação física e dos desportos e dos equipamentos de lazer no Brasil;

II - a adoção de lei de incentivo fiscal para o esporte, com critérios que priorizem a juventude e promovam a equidade;

III - a valorização do desporto e do paradesporto educacional;

IV - a oferta de equipamentos comunitários que permitam a prática desportiva, cultural e de lazer.

E no Art. 30 fala que todas as escolas deverão buscar pelo menos um local apropriado para a prática de atividades poliesportivas, e a Secretaria Nacional de Juventude (s.d) $)^{18}$ diz que:

Para que todo jovem alcance seu pleno desenvolvimento e tenha qualidade de vida, o Estatuto da Juventude aponta o esporte e o lazer como um direito. O Estatuto demanda, a adoção de leis de incentivo fiscal para o esporte, a oferta de equipamentos comunitários para prática esportiva, cultural e de lazer, e a valorização do esporte praticado por jovens com deficiência. Todas as escolas deverão buscar pelo menos um local apropriado para a prática de atividades poliesportivas.

A Seção IX trata do Direito ao Território e à Mobilidade, no Art. 31 menciona que jovem tem direito ao território e à mobilidade, incluindo a promoção de políticas públicas de moradia, circulação e equipamentos públicos, no campo e na cidade. Ao jovem com deficiência devem ser garantidas a acessibilidade e as adaptações necessárias.

Sobre esse tema o Art. 32 menciona que no sistema de transporte coletivo interestadual deverá ser observados os termos da legislação específica: I - a reserva de 2 (duas) vagas gratuitas por veículo para jovens de baixa renda; II - a reserva de 2 (duas) vagas por veículo com desconto de 50\% (cinquenta por cento), no mínimo, no valor das passagens, para os jovens de baixa renda, a serem utilizadas após esgotadas as vagas previstas no inciso I.

E o Art. 33 diz que a União envidará esforços, em articulação com os Estados, o Distrito Federal e os Municípios, para promover a oferta de transporte público subsidiado para

${ }^{18}$ Ibidem 
os jovens, com prioridade para os jovens em situação de pobreza e vulnerabilidade, na forma do regulamento.

O Estatuto diz na Seção $X$ do Direito à Sustentabilidade e ao Meio Ambiente, o Art. 34 tras que o jovem tem direito à sustentabilidade e ao meio ambiente ecologicamente equilibrado, bem de uso comum do povo, essencial à sadia qualidade de vida, e o dever de defendê-lo e preservá-lo para a presente e as futuras gerações, e no Art. 35 fala que o Estado promoverá, em todos os níveis de ensino, a educação ambiental voltada para a preservação do meio ambiente e a sustentabilidade, de acordo com a Política Nacional do Meio Ambiente.

Ainda quanto à questão ambiental o Art. 36 menciona que na elaboração, na execução e na avaliação de políticas públicas que incorporem a dimensão ambiental, o poder público deverá considerar: I - o estímulo e o fortalecimento de organizações, movimentos, redes e outros coletivos de juventude que atuem no âmbito das questões ambientais e em prol do desenvolvimento sustentável; II - o incentivo à participação dos jovens na elaboração das políticas públicas de meio ambiente; III - a criação de programas de educação ambiental destinados aos jovens; e IV - o incentivo à participação dos jovens em projetos de geração de trabalho e renda que visem ao desenvolvimento sustentável nos âmbitos rural e urbano. E no parágrafo único fala que na aplicação do disposto no inciso IV do caput deve observar a legislação específica sobre 0 direito à profissionalização e à proteção no trabalho dos adolescentes.

Um tema de extrema relevância para o programa, alvo de estudo nesta dissertação é tratado na Seção XI que fala sobre o Direito à Segurança Pública e ao Acesso à Justiça. No Art. 37 menciona que todos os jovens têm direito de viver em um ambiente seguro, sem violência, com garantia da sua incolumidade física e mental, sendo-lhes asseguradas a igualdade de oportunidades e facilidades para seu aperfeiçoamento intelectual, cultural e social.

As políticas de segurança pública voltadas para os jovens, tratadas no Art. 38, fala que deverá haver articulação das ações da União, dos Estados, do Distrito Federal e dos Municípios e ações não governamentais, tendo por diretrizes: I - a integração com as demais políticas voltadas à juventude; II - a prevenção e enfrentamento da violência; III - a promoção de estudos e pesquisas e a obtenção de estatísticas e informações relevantes para subsidiar as ações de segurança pública e permitir a avaliação periódica dos impactos das políticas públicas quanto às causas, às consequências e à frequência da violência contra os jovens; IV a priorização de ações voltadas para os jovens em situação de risco, vulnerabilidade social e egressos do sistema penitenciário nacional; V - a promoção do acesso efetivo dos jovens à Defensoria Pública, considerando as especificidades da condição juvenil; e VI - a promoção do efetivo acesso dos jovens com deficiência à justiça em igualdade de condições com as demais pessoas, inclusive mediante a provisão de adaptações processuais adequadas a sua idade.

O Titulo II, Capítulo I, trata do SISTEMA NACIONAL DE JUVENTUDE SINAJUVE, o Art. 39 faz menção a sua instituição, composição, organização, competência, 
funcionamento e financinamento que deveriam ser definidos em regulamento, e no Capítulo II, trata das competências, que são cumulativas, da União, dos Estados e dos Municípios ${ }^{19}$.

${ }^{19}$ À União compete:

I - formular e coordenar a execução da Política Nacional de Juventude;

II - coordenar e manter o Sinajuve;

III - estabelecer diretrizes sobre a organização e o funcionamento do Sinajuve;

IV - elaborar o Plano Nacional de Políticas de Juventude, em parceria com os Estados, o Distrito Federal, os Municípios e a sociedade, em especial a juventude;

$\mathrm{V}$ - convocar e realizar, em conjunto com o Conselho Nacional de Juventude, as Conferências Nacionais de Juventude, com intervalo máximo de 4 (quatro) anos;

VI - prestar assistência técnica e suplementação financeira aos Estados, ao Distrito

Federal e aos Municípios para o desenvolvimento de seus sistemas de juventude;

VII - contribuir para a qualificação e ação em rede do Sinajuve em todos os entes da Federação;

VIII - financiar, com os demais entes federados, a execução das políticas públicas de juventude;

IX - estabelecer formas de colaboração com os Estados, o Distrito Federal e os Municípios para a execução das políticas públicas de juventude; e

$X$ - garantir a publicidade de informações sobre repasses de recursos para financiamento das políticas públicas de juventude aos conselhos e gestores estaduais, do Distrito Federal e municipais.

Aos Estados compete:

I - coordenar, em âmbito estadual, o Sinajuve;

II - elaborar os respectivos planos estaduais de juventude, em conformidade com o Plano Nacional, com a participação da sociedade, em especial da juventude;

III - criar, desenvolver e manter programas, ações e projetos para a execução das políticas públicas de juventude;

IV - convocar e realizar, em conjunto com o Conselho Estadual de Juventude, as Conferências Estaduais de Juventude, com intervalo máximo de 4 (quatro) anos;

$\mathrm{V}$ - editar normas complementares para a organização e o funcionamento do Sinajuve, em âmbito estadual e municipal;

VI - estabelecer com a União e os Municípios formas de colaboração para a execução das políticas públicas de juventude; e

VII - cofinanciar, com os demais entes federados, a execução de programas, ações e projetos das políticas públicas de juventude.

Parágrafo único. Serão incluídos nos censos demográficos dados relativos à população jovem do País.

Aos Municípios compete:

I - coordenar, em âmbito municipal, o Sinajuve;

II - elaborar os respectivos planos municipais de juventude, em conformidade com os respectivos Planos Nacional e Estadual, com a participação da sociedade, em especial da juventude;

III - criar, desenvolver e manter programas, ações e projetos para a execução das políticas públicas de juventude;

IV - convocar e realizar, em conjunto com o Conselho Municipal de Juventude, as Conferências Municipais de Juventude, com intervalo máximo de 4 (quatro) anos;

$\mathrm{V}$ - editar normas complementares para a organização e funcionamento do Sinajuve, em âmbito municipal;

$\mathrm{VI}$ - cofinanciar, com os demais entes federados, a execução de programas, ações e projetos das políticas públicas de juventude; e

VII - estabelecer mecanismos de cooperação com os Estados e a União para a execução das políticas públicas de juventude.

Parágrafo único. Para garantir a articulação federativa com vistas ao efetivo cumprimento das políticas públicas de juventude, os Municípios podem instituir os consórcios de que trata a Lei $\mathrm{n}^{\circ}$-11.107, de 6 de abril de 2005, ou qualquer outro instrumento jurídico adequado, como forma de compartilhar responsabilidades 
O capítulo III do Estatuto vem tratando dos Conselhos de Juventude, no Art. 45 diz que os conselhos de juventude são órgãos permanentes e autônomos, não jurisdicionais, encarregados de tratar das políticas públicas de juventude e da garantia do exercício dos direitos do jovem, com os seguintes objetivos:

I - auxiliar na elaboração de políticas públicas de juventude que promovam o amplo exercício dos direitos dos jovens estabelecidos nesta Lei;

II - utilizar instrumentos de forma a buscar que o Estado garanta aos jovens o exercício dos seus direitos;

III - colaborar com os órgãos da administração no planejamento e na implementação das políticas de juventude;

IV - estudar, analisar, elaborar, discutir e propor a celebração de instrumentos de cooperação, visando à elaboração de programas, projetos e ações voltados para a juventude;

V - promover a realização de estudos relativos à juventude, objetivando subsidiar o planejamento das políticas públicas de juventude;

VI - estudar, analisar, elaborar, discutir e propor políticas públicas que permitam e garantam a integração e a participação do jovem nos processos social, econômico, político e cultural no respectivo ente federado;

VII - propor a criação de formas de participação da juventude nos órgãos da administração pública;

VIII - promover e participar de seminários, cursos, congressos e eventos correlatos para o debate de temas relativos à juventude;

IX - desenvolver outras atividades relacionadas às políticas públicas de juventude.

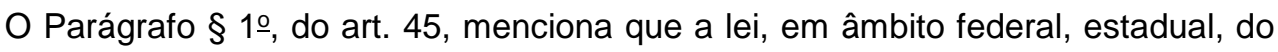
Distrito Federal e municipal, disporá sobre a organização, o funcionamento e a composição dos conselhos de juventude, observada a participação da sociedade civil mediante critério, no mínimo, paritário com os representantes do poder público.

O Art. 46 menciona as atribuições dos conselhos de juventude:

I - encaminhar ao Ministério Público notícia de fato que constitua infração administrativa ou penal contra os direitos do jovem garantidos na legislação;

II - encaminhar à autoridade judiciária os casos de sua competência;

III - expedir notificações;

IV - solicitar informações das autoridades públicas;

V - assessorar o Poder Executivo local na elaboração dos planos, programas, projetos, ações e proposta orçamentária das políticas públicas de juventude.

E o Art. 47 menciona que sem prejuízo das atribuições dos conselhos de juventude com relação aos direitos previstos neste Estatuto, cabe aos conselhos de direitos da criança e do adolescente deliberar e controlar as ações em todos os níveis relativas aos adolescentes com idade entre 15 (quinze) e 18 (dezoito) anos.

\subsection{Plano Nacional de Educação - PNE - Lei 13.005 de 25 de junho de 2014.}

O Estatuto da Juventude, mencionado no item anterior, deu base para a formulação de ações e planos especificamente desenhados para atender a população Jovem. 
O Plano Nacional de Educação, apesar de ser uma Política Pública com metas, é citado neste capítulo, que trata dos Marcos Legais para a Educação da Juventude, porque foi introduzido na educação por meio de lei.

O Plano Nacional de Educação - PNE 2014 -2024, que tramitou quatro anos até virar lei, vem de diretrizes que buscam uma educação mais igualitária e de qualidade. Para tanto propõe 20 metas e estratégias para o ensino no país em todos os níveis (infantil, básico e superior). O PNE propôs que Estados, municípios e federação terão dez anos para alcançar os objetivos propostos.

A meta 9, especificamente, fala da oferta de oportunidades educacionais a quase 14 milhões de brasileiros com mais de 15 anos que, no Censo de 2010, se auto-declaram analfabetos, fala, ainda, em garantir que jovens e adultos com escolaridade baixa ou de qualidade insuficiente aprimorem suas habilidades de leitura, escrita e compreensão da linguagem matemática, de modo a assegurar suas possibilidades de desenvolvimento pessoal e social. (Observatório do PNE, sd)

As Metas 9 e 10 referem-se à educação de jovens e adultos, as duas são bastante audaciosas e mencionam a elevação da taxa de alfabetização da população com 15 (quinze) anos ou mais para 93,5\% (noventa e três inteiros e cinco décimos por cento) até o final 2015 e, até o final da vigência do PNE, erradicar o analfabetismo absoluto e reduzir em $50 \%$ (cinquenta por cento) a taxa de analfabetismo funcional.

Com relação à Meta 10: "Oferecer no mínimo, 25\% das matrículas de Educação de Jovens e Adultos na forma integrada à Educação Profissional, nos ensinos fundamental e médio". De acordo com o Todos pela Educação (2015): "As estatísticas mostram que, mesmo após o estímulo criado pelo Fundeb, ao ampliar o financiamento dessa modalidade de ensino, as matrículas vêm caindo". A seguir, serão mostradas tabelas elaboradas pelo Todos pela Educação (2015) que ilustram a realidade da Educação de Jovens e Adultos.

Figura 1: Total de matrículas na EJA integrada à Educação Profissional

\begin{tabular}{|c|c|c|c|c|c|c|c|}
\hline & \multirow[b]{2}{*}{ Total EJA } & \multicolumn{3}{|c|}{ Nivel Fundamental } & \multicolumn{3}{|c|}{ Nivel Médio } \\
\hline & & Total & $\begin{array}{l}\text { Integrado } \\
\text { à Educaçăo } \\
\text { Profissional }\end{array}$ & $\begin{array}{c}\text { \% matrículas } \\
\text { quando } \\
\text { integrado } \\
\text { à Educação } \\
\text { Profissional }\end{array}$ & Total & $\begin{array}{l}\text { Integrado } \\
\text { à Educaçāo } \\
\text { Profissional }\end{array}$ & $\begin{array}{c}\% \text { matriculas } \\
\text { quando } \\
\text { integrado } \\
\text { à Educação } \\
\text { Profissional }\end{array}$ \\
\hline Brasil & 3.772 .670 & 2.447 .792 & 20.194 & 0,82 & 1.324 .878 & 41.269 & 3,11 \\
\hline Norte & 499.605 & 357.374 & 2.270 & 0,64 & 142.231 & 4.107 & 2,89 \\
\hline Nordeste & 1.514 .727 & 1.143 .437 & 16.617 & 1,45 & 371.290 & 25.979 & 7,00 \\
\hline Sudeste & 1.149 .289 & 608.140 & 549 & 0,09 & 541.149 & 6.379 & 1,18 \\
\hline Sul & 356.609 & 200.791 & 443 & 0,22 & 155.818 & 3.037 & 1,95 \\
\hline Centro-Oeste & 252.440 & 138.050 & 315 & 0,23 & 114.390 & 1.767 & 1,54 \\
\hline
\end{tabular}

Fonte: MEC/nnep/DEED - Sinopse Estatistica da Educaçăo Básica. Nota: O mesmo aluno pode ter mais de uma matricula. 
Figura2: Matrículas por etapa de ensino - Brasil - 2007 -2013

Educação de Jovens e Adultos

Matriculas por etapa de ensino - Brasil - 2007-2013

\begin{tabular}{|c|c|c|c|c|c|c|c|c|c|}
\hline \multirow[b]{3}{*}{ Ano } & \multicolumn{9}{|c|}{ Matriculas na Educação de Jovens e Adultos por etapa de ensino } \\
\hline & \multirow[b]{2}{*}{$\begin{array}{l}\text { Total } \\
\text { geral }\end{array}$} & \multicolumn{5}{|c|}{ Ensino Fundamental } & \multicolumn{3}{|c|}{ Ensino Médio } \\
\hline & & Total & $\begin{array}{c}\text { Anos } \\
\text { Iniciais }\end{array}$ & $\begin{array}{l}\text { Anos } \\
\text { Finais }\end{array}$ & $\begin{array}{l}\text { Integrado } \\
\text { à Educação } \\
\text { Profissional }\end{array}$ & $\begin{array}{l}\text { Projovem } \\
\text { (Urbano) }\end{array}$ & Total & Médio & $\begin{array}{l}\text { Integrado } \\
\text { à Educação } \\
\text { Profissional }\end{array}$ \\
\hline 2007 & 4.985 .338 & 3.367 .032 & 1.160 .879 & 1.974 .940 & $\ldots$ & $\ldots$ & 1.618 .306 & 1.608 .559 & 9.747 \\
\hline 2008 & 4.945 .424 & 3.295 .240 & 1.127.077 & 2.164 .187 & 3.976 & $\ldots$ & 1.650 .184 & 1.635 .245 & 14.939 \\
\hline 2009 & 4.661 .332 & 3.094 .524 & 1.035 .610 & 2.055 .286 & 3.628 & $\ldots$ & 1.566 .808 & 1.547 .275 & 19.533 \\
\hline 2010 & 4.287 .234 & 2.860 .230 & 923.197 & 1.922 .907 & 14.126 & $\ldots$ & 1.427 .004 & 1.388 .852 & 38.152 \\
\hline 2011 & 4.046 .169 & 2.681 .776 & 935.084 & 1.722 .697 & 23.995 & $\ldots$ & 1.364 .393 & 1.322 .422 & 41.971 \\
\hline 2012 & 3.906 .877 & 2.561 .013 & 870.181 & 1.618 .587 & 18.622 & 53.623 & 1.345 .864 & 1.309 .871 & 35.993 \\
\hline 2013 & 3.772 .670 & 2.447 .792 & 832.754 & 1.551 .438 & 20.194 & 43.406 & 1.324 .878 & 1.283 .609 & 41.269 \\
\hline$\Delta \% 2012 / 2013$ & $-3,44$ & $-4,42$ & $-4,30$ & $-4,15$ & 8,44 & $-19,05$ & $-1,56$ & $-2,00$ & 14,66 \\
\hline
\end{tabular}

Fonte: MEC/Inep/DEED - Microdados Censo Escolar - Elaboraçăo: Todos Pela Educaçåo.

Figura 3: Matrículas no Ensino Fundamental - Brasil e regiões - 2013

Educação de Jovens e Adultos

Matriculas no Ensino Fundamental - Brasil e regiōes - 2013

\begin{tabular}{l|c|c|c|c|c}
\hline & Total & Presencial & Semipresencial & Integrada presencial & $\begin{array}{c}\text { Integrada } \\
\text { semipresencial }\end{array}$ \\
\hline Brasil & $\mathbf{2 . 4 4 7 . 7 9 2}$ & $\mathbf{2 . 2 3 3 . 0 5 3}$ & $\mathbf{1 9 4 . 5 4 5}$ & $\mathbf{1 8 . 9 2 3}$ & $\mathbf{1 . 2 7 1}$ \\
\hline Norte & $\mathbf{3 5 7 . 3 7 4}$ & 332.723 & 22.381 & 1.925 & 345 \\
\hline Nordeste & $\mathbf{1 . 1 4 3 . 4 3 7}$ & 1.096 .500 & 30.320 & 15.904 & 713 \\
\hline Sudeste & $\mathbf{6 0 8 . 1 4 0}$ & 488.770 & 118.821 & 370 & 179 \\
\hline Sul & $\mathbf{2 0 0 . 7 9 1}$ & 180.546 & 19.802 & 419 & 24 \\
\hline Centro-Oeste & 138.050 & 134.514 & 3.221 & 305 & 10
\end{tabular}

Fonte: MEC/Inep/DEED - Sinopse Estatistica da Educação Bäsica.

Nota: $O$ mesmo aluno pode ter mais de uma matricula.

Figura 4: Matrículas no Ensino Médio - Brasil e regiões - 2013

Educação de Jovens e Adultos

Matriculas no Ensino Médio - Brasil e regiōes - 2013

\begin{tabular}{l|r|r|r|r|r}
\hline & Total & Presencial & Semipresencial & Integrada presencial & $\begin{array}{c}\text { Integrada } \\
\text { semipresencial }\end{array}$ \\
\hline Brasil & $\mathbf{1 . 3 2 4 . 8 7 8}$ & $\mathbf{1 . 0 2 1 . 4 5 7}$ & $\mathbf{2 6 2 . 1 5 2}$ & $\mathbf{4 0 . 1 1 7}$ & $\mathbf{1 . 1 5 2}$ \\
\hline Norte & $\mathbf{1 4 2 . 2 3 1}$ & 115.201 & 22.923 & 4.107 & - \\
\hline Nordeste & $\mathbf{3 7 1 . 2 9 0}$ & 296.067 & 49.244 & 25.427 & 552 \\
\hline Sudeste & $\mathbf{5 4 1 . 1 4 9}$ & 388.125 & 146.645 & 5.948 & 431 \\
\hline Sul & $\mathbf{1 5 5 . 8 1 8}$ & 112.517 & 40.264 & 2.920 & 117 \\
\hline Centro-Oeste & $\mathbf{1 1 4 . 3 9 0}$ & 109.547 & 3.076 & 1.715 & 52
\end{tabular}

Fonte: MEC/Inep/DEED - Sinopse Estatística da Educação Bäsica.

Nota: O mesmo aluno pode ter mais de uma matricula. 
Essa baixa escolaridade verificada na população brasileira adulta tem impactos nas áreas da saúde, nas atividades econômicas e na participação cidadã das pessoas e das comunidades, bem como, na forte correlação entre baixa escolaridade dos pais e resultados educacionais dos filhos. (Lazáro, 2010).

E Sen (2000), ensina que as políticas públicas surgem para tentar minimizar determinadas situações e que ninguém pode ser contra as reivindicações básicas de saúde, educação, condições de moradia digna, entre outras, e essas necessidades básicas devem ser providas pelo Estado ou organismos sociais.

Com relação à Meta 10, esta menciona a oferta de, no mínimo, 25\% (vinte e cinco por cento) das matrículas de educação de jovens e adultos, nos ensinos fundamental e médio, na forma integrada à educação profissional.

De acordo com Basílio (2014, p.01):

O contexto da educação de jovens e adultos (EJA) intensifica ainda mais seus desafios: a modalidade lida com indivíduos que não cumpriram trajetórias escolares ou que foram tolhidos durante a tentativa. Isso congrega, em uma mesma etapa escolar, diversas expectativas de aprendizagem, habilidades e fases do desenvolvimento humano que deveriam ser amparadas por propostas pedagógicas bastante específicas.

De modo geral, os especialistas avaliam que a EJA está longe de responder a um de seus principais dilemas: "o que fazer com sujeitos que já trazem o estigma do fracasso escolar?". A dificuldade em responder esta questão tem como consequência a perpetuação de uma visão empobrecida e pouco inovadora do processo educacional. $O$ ensino de jovens e adultos deve ter um recorte próprio da educação a partir de uma perspectiva voltada para a integração dos indivíduos à sociedade, para que ele se coloque como um ser crítico. Deve ser garantido o trabalho com o conteúdo, mas também a participação social e o desenvolvimento humano. (Basílio, 2014, p. 01) 


\section{CAPÍTULO 2: POLÍTICAS PÚBLICAS PARA A JUVENTUDE}

Tratando-se o Projovem Urbano de uma política pública, é pertinente mencionar sobre os conceitos de política pública e o seu ciclo, mas, antes trataremos do conceito de Juventude. A Organização das Nações Unidas define juventude como a faixa de indivíduos com 15 a 24 anos de idade. A Organização Mundial da Saúde define como uma categoria sociológica que implica na preparação dos indivíduos para o exercício da vida adulta, tanto no plano familiar quanto no profissional, abrangendo a faixa dos 15 aos 24 anos de idade (OMS/OPS, 1985). Mas é certo que a definição etária de juventude pode variar de país para país (UNFPA, 2010).

A Lei no 12.852 , de 05 de agosto de 2013, trouxe a definição legal de população jovem no Brasil em seu artigo 1ํㅡ § 1ํ: "Para os efeitos desta Lei, são consideradas jovens as pessoas com idade entre 15 (quinze) e 29 (vinte e nove) anos de idade".

\subsection{Políticas Públicas - Conceitos e o ciclo}

Segundo Façanha e Lima (2011) o conceito de políticas públicas, no Brasil, começou a ganhar contornos e formas mais definidas a partir da Constituição Federal promulgada em 1988, e hoje podem ser entendidas como o conjunto de ações, metas e planos que os governos (nacionais, estaduais ou municipais) elaboram e executam para atender 0 interesse público e oferecer melhores condições de vida à população. Os conceitos que asseguram a base dessa dissertação são os formulados pelos seguintes autores: Howlett e Ramesch, Tomas Dye, Jenkins, Gelinski e Seibel, Secchi e Ruas.

Segundo Howlett e Ramesch (2003) as políticas públicas resultam de decisões tomadas por governos para adotar ou não certas políticas. E Dye (1995), reafirma este conceito dizendo que política pública é qualquer coisa que o governo decide fazer ou não fazer.

A autora Rua (2009, p.21) menciona que políticas públicas são "resultantes da atividade política e que esta consiste na resolução pacífica de conflitos, processo essencial à preservação da vida em sociedade". O conceito parte do princípio de que a sociedade se forma como o agregado de indivíduos que têm interesses e necessidades próprias e que, inclusive, possuem capacidades diferenciadas para supri-las.

Gelinski e Seibel (2008) definem políticas públicas como ações governamentais dirigidas a resolver determinadas necessidades públicas. As políticas podem ser sociais, macroeconômicas, ou outras (científica e tecnológica, cultural, agrícola, agrária). Usualmente o ciclo das políticas é concebido como o processo de formulação, implementação, acompanhamento e avaliação.

Segundo Secchi (2012) qualquer definição de política pública é arbitrária, isto porque na literatura especializada não há um consenso quanto à definição do que seja uma política pública haja vista a disparidade de respostas para questionamentos básicos, como por exemplo, se as políticas públicas são elaboradas exclusivamente por atores estatais ou não 
estatais.

Secchi (2012, p. 02) apresenta um conceito na mesma linha de Rua, mencionando que:

Uma política pública é uma diretriz elaborada para enfrentar um problema público. [...] em outras palavras, a razão para o estabelecimento de uma política pública é o tratamento ou a resolução de um problema entendido como coletivamente relevante.

Considera-se importante trazer também o conceito de políticas sociais, já que políticas públicas e políticas sociais são conceitos diferentes.

Segundo Castro et al (2009, p.334), políticas sociais são um subconjunto das políticas públicas relacionado a ações que determinam o padrão de proteção social implementado pelo Estado e se relacionam à distribuição de benefícios sociais para minimizar as desigualdades estruturais advindas da trajetória do desenvolvimento socioeconômico, usualmente nas áreas de educação, saúde, previdência, habitação,saneamento etc., e executadas sob a responsabilidade do Estado.

Frente a diversas situações, como desemprego, analfabetismo, pobreza, desigualdades sociais, o Estado precisa intervir através de políticas públicas e sociais no sentido de diminuir tais situações. Ao contrário do que diz o conceito liberal, as políticas públicas e sociais não ameaçam as liberdades individuais, pelo contrário, as políticas públicas e sociais podem desenvolver a capacidade humana, bem como dar um leque de liberdade de escolha defendida por Amartya Sen (2002).

Após a apresentação do conceito de políticas públicas, é importante discorrer, de forma sucinta, sobre o ciclo da política pública.

\subsection{Ciclo das Políticas Públicas}

O ciclo das políticas públicas (processo de elaboração de políticas públicas), segundo Secchi (2012, p. 33): "é um esquema de visualização e interpretação que organiza a vida de uma política pública em fases sequenciais e interdependentes."

Façanha e Lima (2011) explicam que até serem transformadas em lei, as políticas públicas passam por vários ciclos ou fases: 1)Formação da Agenda (seleção das prioridades); 2) Formulação de Políticas (apresentação de soluções ou alternativas); 3) Processo de Tomada de Decisão (escolha das ações); 4) Implementação (ou execução das ações); 5) Avaliação. Esses ciclos e fases interligam-se entre si, pois constituem um processo em ciclos.

Já para Secchi (2012), seriam sete fases: 1) identificação do problema; 2) formação de agenda; 3) formulação de alternativas; 4) tomada de decisões; 5) implementação; 6) avaliação; e 7) extinção.

Como a intenção deste trabalho não é apresentar de forma detalhada cada fase, cada uma delas será discorrida, de forma sucinta, a seguir. 


\subsubsection{Identificação do problema}

A primeira fase de uma política pública é a identificação do problema. Secchi (2012, p. 34) menciona que um problema pode surgir diante de vários fatores, tais como: a) catástrofe natural que afete a vida de pessoas de determinada região; b) quando começa a ter relevância gradativamente, como, por exemplo, o congestionamento nas cidades; e c) quando o problema existe já há algum tempo, contudo a coletividade já aprendeu a conviver com ela. É certo que a fase de identificação do problema público envolve a percepção do problema, a definição ou delimitação do problema e a avaliação da possibilidade de resolução.

Secchi (2012, p. 35) diz que" um problema nem sempre é reflexo da deterioração de determinado contexto, mas sim de melhora da situação em outro contexto."

Um aspecto importante que Secchi (2012, p. 35) menciona é que se um problema é identificado por algum ator político e este tem interesse na busca de solução, tal problema pode entrar na lista de prioridades de atuação conhecida como agenda.

\subsubsection{Formação de Agenda}

Agenda pode ser definida como a lista de assuntos ou problemas aos quais os funcionários do governo e pessoas associadas a esse governo estão devotando o seu tempo. Castro (s/d) define agenda como sendo a inclusão de demanda social ou necessidade social na lista de prioridades do Poder Público.

Secchi (2012, p. 36) menciona que a agenda é um conjunto de problemas ou temas entendidos como relevantes podendo tomar forma de um programa de governo, um planejamento orçamentário, um estatuto partidário ou uma simples lista de assuntos que o comitê editorial de um jornal entende como importante.

Rua (s/d, e, p. 07) explica que: "A fase da formação da agenda ou agenda-setting é o período mais ou menos prolongado, quando é decidido se um tema vai ser efetivamente incluído na pauta política atual, se deve ser adiado para uma data posterior ou se deve ser excluído, não obstante a sua relevância".

Depois que um problema entra na agenda há a formulação de alternativas.

\subsubsection{Formulação de alternativas}

Rua (s/d, e, p. 09) explica que: "na fase de formulação escolhe-se a mais apropriada entre as várias alternativas de ação, quando a decisão é formalizada por meio de uma norma jurídica pela autoridade competente".

Segundo Secchi (2012, p.37) a formulação de alternativas de solução se desenvolve através de escrutínios formais e informações das consequências do problema e dos potenciais custos e benefícios de cada alternativa possível. Para ele a etapa de construção de alternativas é a fase em que são elaborados métodos, programas, estratégias ou ações que poderão alcançar os objetivos estabelecidos, sendo que um objetivo pode ser alcançado de 
várias formas, por diversos caminhos.

\subsubsection{Tomada de decisão}

Depois que as alternativas já foram formuladas, acontece a tomada de decisão na qual acontece o processo pelo qual são escolhidas algumas e muitas alternativas.

Secchi (2012, p.40) menciona que a tomada de decisões é vista como a etapa que sucede a formulação de alternativas de solução. Esta fase representa o momento em que os interesses dos atores são equacionados e as intenções de enfrentamento de um problema público são enfrentados.

Para o autor existem três formas de entender a dinâmica de escolha de alternativas de solução para problemas públicos: a) os tomadores de decisão têm problemas e correm atrás de soluções; b) os tomadores de decisão vão ajustando os problemas às soluções, e as soluções aos problemas; e c) os tomadores de decisão têm soluções em mãos e correm atrás de problemas.

\subsubsection{Implementação da Política Pública}

É na fase de implementação que as regras, rotinas e processos sociais são convertidos de intenções em ações.

Rua (s/d, e, p. 10) explica que: "a implementação consiste no conjunto de ações realizadas por indivíduos, grupos ou organizações, de natureza pública ou privada, direcionadas para a consecução de objetivos estabelecidos mediante decisões anteriores sobre políticas públicas."

Como este estudo trata de uma política publica nacional, é importante dizer que a implementação de uma política depende, na maioria das vezes, de acordos de adesão intergovernamentais que envolvem a participação de atores locais para que a política seja levada adiante.

A implementação é a fase em que as políticas públicas já formuladas entram em ação e são colocadas em prática. Existem dois modelos de implementação de políticas públicas: a) top down (de cima para baixo): separação clara entre o momento de tomada de decisão e o de implementação em fases consecutivas; b) bottom-up (de baixo para cima): caracterizado pela maior liberdade de burocratas e redes de atores em auto-organizar e modelar a implementação de Políticas Públicas. (Secchi, 2012, p.44).

\subsubsection{Avaliação de Políticas Públicas}

Após a implementação, ou execução, da Política Pública, tem-se a próxima fase, que é a avaliação das políticas.

Secchi (2012, p 49) explica que a avaliação é a fase em que o processo de implementação e o desempenho da política pública são examinados com a finalidade de conhecer melhor o estado da política e o nível de redução do problema que a gerou. É 
importante mencionar que a avaliação de políticas públicas, segundo Secchi (2012) pode levar à continuidade da política como está, reestruturação marginal de aspectos práticos da política pública e extinção da política pública.

A avaliação das políticas públicas pode acontecer em diversos momentos da implementação, que também são denominadas de monitoramento, ou pós implementação. Todavia, alguns autores como Rua ( $/ \mathrm{d}, \mathrm{a}$ ), mencionam que são processos distintos. Assim explica Rua (s/d, a, p. 01): "No ciclo do programa o monitoramento é contínuo e acompanha todo o período da implementação, enquanto que a avaliação é pontual, discreta".

\subsubsection{Extinção da política pública}

A partir de um estudo realizado nos anos 70 sobre o término ou extinção de políticas públicas nos países desenvolvidos construiu-se uma base teórica para o entendimento de que as políticas públicas morrem, continuam vivas ou são substituídas por outras. (Secchi, 2012, p. 53). A extinção pode acontecer porque o problema que originou o problema é solucionado ou por que os programas ou ações tomadas são ineficazes para resolver a questão ou porque o problema perdeu importância e saiu da agenda.

O Programa Projovem Urbano seguiu o ciclo das políticas públicas desde a identificação do problema e da formação da agenda, como visto no capítulo anterior, até a implementação da política, sendo que durante o processo a tomada de decisão foi uma etapa que passou por algumas reformulações até se chegar nos moldes do programa atual. Como já mencionado, no Brasil, havia 3,4 milhões de jovens entre 18 a 24 anos que, além de não terem concluído o ensino fundamental se encontravam fora do mercado de trabalho. Diante desta realidade, pensar políticas públicas para a juventude entrou na agenda do governo brasileiro.

O primeiro passo foi a constituição de um GT que ficou responsável em mapear e analisar as políticas públicas, dados, estudos e diagnósticos sobre a população jovem no Brasil. A partir deste trabalho, o GT, verificou que havia nove desafios que deveriam pautar a Política Nacional da Juventude, dentre eles destacavam-se a ampliação do acesso e permanência na escola e a preparação para o mercado de trabalho.

Esse GT verificou ainda que havia em torno de 34 milhões de jovens na faixa etária de 15 a 24 anos que estavam desempregados, tinham abandonado a escola, não tinham formação profissional, alto índice de morte por homicídio, envolvimento com drogas e com criminalidade e somado a isso havia ainda a falta de políticas públicas para o público jovem na faixa etária de 18 a 24 anos.

Em 2005 o governo federal instituiu a Política Nacional de Juventude (PNJ), que se destacou como um marco na agenda juvenil e ainda foi criada a Secretaria Nacional de Juventude. A partir desta estrutura, criou-se o Projovem, que caracterizou-se como emergencial, atendendo um segmento que tem necessidade de chegar ainda jovem ao ensino médio, e experimental, baseando sua proposta curricular em novos paradigmas de ensino e aprendizagem que permitem articular o ensino fundamental, a qualificação profissional e a ação 
comunitária ${ }^{20}$.

O Programa foi implementado inicialmente nas 27 Capitais brasileiras. A partir dos estudos desenvolvidos pelas 7 universidades responsáveis pelo Sistema de Monitoramento e Avaliação (SMA), o Programa passou por transformações para melhor atender os jovens de 18 a 29 anos. Atualmente o Programa é coordenado, em âmbito nacional, pelo Ministério da Educação.

\subsection{Histórico das políticas públicas para a juventude no Brasil}

Nos últimos anos, nota-se que políticas públicas voltadas para a juventude e para idosos têm ganhado importância na agenda, e isto, segundo Camarano (et al., 2009) se deve ao fato de que a população jovem tem tendência a diminuir e a população idosa a crescer.

De acordo com os estudos do IPEA (2009) e de Camarano (et al., 2009), a juventude se inscreveu como questão social no mundo contemporâneo a partir de duas abordagens principais, quais sejam: a) jovens associados a delinquência, drogas, violência, etc; e b) a juventude como fase transitória para a vida adulta.

Diante disso, os jovens se caracterizam como o grupo prioritário sobre o qual deveriam recair as ações de controle social tutelar e repressivo, promovidas pela sociedade e pelo poder público IPEA (2009).

Com relação à população jovem, Schmidt et al. (2010) explicam que historicamente houve certa demora por parte do governo brasileiro em desenvolver ações que em longo e médio prazo pudessem qualificar a população que entraria na PEA.

De acordo com Batista (2009, p.08) as políticas públicas de juventude tiveram início nos anos de 1950, nesta época privilegiava-se a integração que depois foi substituída no período militarista/autoritário - pela imposição de controle social dos jovens. Na década de 1980 as políticas focavam no enfrentamento da pobreza e na prevenção da delinqüência. $\mathrm{Na}$ década de 90 as políticas tinham como prioridade os jovens excluídos do mercado de trabalho, e eram poucas as políticas voltadas para os jovens de 18 a 29 anos.

Antes de 1995 pode-se dar destaque a dois programas para essa população: Programa Saúde do Adolescente e do Jovem - PROSAD do Ministério da Saúde e Prêmio Jovem Cientista do Ministério da Ciência e Tecnologia. (Spossito e Carrano, 2003, apud Schmidt et al., 2010).

O PROSAD foi criado pela Portaria do Ministério da Saúde ํo 980/GM de 21/12/1989, tratava-se de uma política de promoção de saúde, de identificação de grupos de risco, detecção precoce dos agravos com tratamento adequado e reabilitação. O público-alvo eram jovens de 10 a 19 anos de idade. Os objetivos do Programa eram: a) Promover a saúde integral do adolescente, favorecendo o processo geral de seu crescimento e desenvolvimento, buscando reduzir a morbi-mortalidade e os desajustes individuais e sociais; b) Normatizar as ações consideradas nas áreas prioritárias; c) Estimular e apoiar a implantação e/ou

\footnotetext{
${ }^{20}$ Histórico Projovem. Disponível em: http://www.pmcg.ms.gov.br/projovem/canaisTexto?id_can=2522
} 
implementação dos Programas Estaduais e Municipais, na perspectiva de assegurar ao adolescente um atendimento adequado às suas características, respeitando as particularidades regionais e realidade local; d) Promover e apoiar estudos e pesquisas multicêntricas relativas a adolescência; e e) Contribuir com as atividades intra e interistitucional, nos âmbitos governamentais e não governamentais, visando a formulação de uma política nacional para a adolescência e juventude, a ser desenvolvida nos níveis Federal, Estadual e Municipal. (Silva, 2005)

O Prêmio Jovem Cientista foi criado em 1981 e tem como objetivo incentivar a pesquisa no País. Trata-se de uma iniciativa do CNPq e do Ministério da Ciência e Tecnologia e o público alvo são estudantes do ensino médio à pós-graduação. Esta iniciativa vigora até os dias atuais, sendo que os resultados dos candidatos inscritos em 2014 foi divulgado em maio de 2015.

No ano de 2003, foi criado o Programa de Estímulo ao Primeiro Emprego (PNPE), pela Lei 10.748 de 2003, sendo alterada pela Lei 10.940 de 2004 e regulamentada pelo Decreto 5.199 de 2004. O Programa era do Ministério do Trabalho e Emprego e seu objetivo era promover a inserção de jovens no mercado de trabalho e sua escolarização, o fortalecimento da participação da sociedade no processo de formulação de políticas e ações de geração de trabalho e renda, objetivando, especialmente, promover: I - a criação de postos de trabalho para jovens ou prepará-los para o mercado de trabalho e ocupações alternativas, geradoras de renda; e II - a qualificação do jovem para o mercado de trabalho e inclusão social.

Guimarães e Almeida ( $\mathrm{s} / \mathrm{d}, \quad$ p. 14) mencionam que o Programa também determinava um número máximo de contratações por empresa, no intuito de inibir a substituição de trabalhadores empregados por outros que gerassem subsídios às empresas. Para os autores: "O PNPE foi importante por colocar na agenda a necessidade de ações específicas. No entanto, não havia naquele momento uma reflexão clara sobre como deveria se dar uma política para a juventude. Tratou-se, portanto, de uma ação isolada".

De acordo com o manual do educador do Projovem quando se fala de inclusão social deve-se saber que os dilemas e as perspectivas da juventude estão inscritos num tempo que conjuga um acelerado processo de globalização e crescentes desigualdades sociais que geram exclusão. No Brasil, tal como pelo mundo afora, os jovens são os mais atingidos, tanto pelas transformações sociais, que tornam o mercado de trabalho excludente e mutante, quanto pelas distintas formas de violência física e simbólica, que caracterizaram a sociedade do fim do século e persistem neste início do século XXI. (MEC/SECADI/Manual do Educador Orientações Gerais, 2012).

Foi entre 1995 e 2002 que as políticas para a juventude começaram a entrar na agenda das políticas públicas, contudo a discussão carecia de mais visibilidade, explicam Schmidt (et al., 2010, p. 07):

(...) a discussão era muito tímida, centrada nos estereótipos de medo 
da perda da juventude para a criminalidade ou para as drogas. Assim, as propostas, tinham como fundamento ocupar o tempo ocioso dos jovens de forma a prepará-los para exercer as responsabilidades da vida adulta. A ampliação do debate e a maior visibilidade dos jovens podem ser percebidas pela quantidade de programas criados entre 1995-2002, ao todo surgiram mais 30 programas/projetos governamentais, incidindo com maior ou menor focalização nas faixas etárias comumente considerados jovens. Destes apenas 18 dirigiam seu foco sobre a juventude.

Em 2005 as políticas voltadas para os jovens sofreram reestruturação. Segundo Guimarães e Almeida (s/d, p. 13):

A ênfase, centrada em estimular a demanda por trabalhadores jovens, foi substituída pela maior preocupação com a capacitação e a empregabilidade do trabalhador. A mudança pode ter sido motivada pela percepção de que o problema maior estava na baixa qualificação do trabalhador e que fortalecer essa qualificação tenderia a ser mais importante do que subvencionar a contratação. No entanto, teria havido também dificuldades operacionais que prejudicaram a eficácia do programa. Muitas empresas menores alegaram encontrar dificuldades para participar do programa. Houve também casos de empresas que não participavam devido às dificuldades de obter certidões negativas de débito junto à União. (Guimarães e Almeida, 2012).

Os autores disseram, ainda, que: "há evidencias de que um melhor desenho, incluindo simplificação de procedimentos e menor burocracia, teria favorecido melhores resultados. Trata-se de uma constatação importante, indicando para a necessidade de preocupação também com o lado da demanda como parte da estratégia para estimular a entrada dos jovens no mercado de trabalho". (Guimarães e Almeida, p. 13).

A partir de então o foco das atenções foi para os Consórcios Sociais da Juventude (CSJ), que constituem instrumento para a consolidação da parceria governo-sociedade e como porta de entrada complementar do Programa, a fim de atingir parte do público jovem e garantir a integração das Políticas Públicas de Emprego.

Segundo Guimarães e Almeida (s/d) as ações são voltadas a favorecer tanto a qualificação como a inclusão social do jovem em situação mais vulnerável. Tratava-se de um programa que privilegiava o envolvimento da sociedade civil e visava atingir áreas onde o Estado tinha mais dificuldade em chegar. Sua principal inovação era combinar qualificação social e profissional, trabalho comunitário e iniciativas para inserção dos jovens no mercado de trabalho, que deveria se dar tanto por meio de práticas de intermediação como pela inserção do trabalhador em práticas não tradicionais, incluindo o trabalho em cooperativas.

Feita a reconstituição histórica das Políticas Públicas para a Juventude, vejamos na sequência a Política Projovem Urbano, alvo dessa dissertação. 


\section{CAPÍTULO 3: PROJOVEM URBANO, POPULAÇÃO JOVEM E O BÔNUS DEMOGRÁFICO.}

\subsection{Projovem original}

De 2003 para cá, como já foi mencionado, muitas políticas para jovens estão sendo implementadas. Uma das mais recentes foi o Projovem Urbano, que inicialmente foi denominado apenas de Projovem.

Em 2004 foi criado o Grupo de Trabalho Interministerial da Juventude - GT, para mapear e analisar as políticas públicas, dados, estudos e diagnósticos sobre a população jovem no Brasil, o qual identificou nove desafios que deveriam pautar a Política Nacional da Juventude, entre eles destacam-se: ampliação do acesso e permanência na escola e a preparação para o mercado de trabalho (Schmidt et. al., 2010).

Schmidt et. al. (2010) mencionam que o GT verificou que havia em torno de 34 milhões de jovens na faixa etária de 15 a 24 anos que se encontravam atingidos pelos piores índices de desemprego, evasão escolar, falta de formação profissional, morte por homicídio, envolvimento com drogas e com criminalidade. E junto com este contexto havia ainda a falta de políticas públicas para o público jovem, mais especificamente na faixa etária de 18 a 24 anos.

Já em 2005 o governo federal instituiu a Política Nacional de Juventude (PNJ), que se destacou como um marco na agenda juvenil, vista apenas como uma fase de transição da adolescência para a vida adulta. Em parte, até mesmo, pela nomenclatura dada pelo Estatuto da Criança e do Adolescente, que descrevia esta população como os brasileiros com idade até 18 anos. Após essa idade todos eram tidos como adultos, sem que houvesse distinção das suas particularidades ${ }^{21}$.

A partir disso, em junho de 2005, veio a Medida Provisória $n^{\circ}$ 238/2005, que instituiu o Projovem ${ }^{22}$, sendo, posteriormente, convertida na Lei no 11.129/2005, regulamentada pelo Decreto $n^{\circ} 5.557$, de 05/10/2005, definindo em seu artigo $2^{\circ}$ em que a finalidade do Programa era executar ações integradas que propiciassem aos jovens brasileiros, na forma de curso previsto no art. 81 da Lei n 9.394/96, a elevação da escolaridade dos jovens, visando à conclusão do Ensino Fundamental, à qualificação profissional, em nível de formação inicial, voltada a estimular a inserção produtiva cidadã e ao desenvolvimento de ações comunitárias com práticas de solidariedade, exercício de cidadania e intervenção na realidade local. (MEC/SECADI/Manual do Educador Orientações Gerais, 2012).

O Programa foi aprovado pela Câmara de Educação Básica do Conselho Nacional de Educação (Parecer CNE/CEB no 2/2005, de 16/03/2005 e Resolução CNE/CEB no 3/2006, de 15/08/2006) como um curso experimental, de acordo com o artigo $n^{\circ} 81$ da Lei de Diretrizes e Bases da Educação Nacional (LDB), com 12 meses de duração. Schmidt et. al. (2010)

\footnotetext{
${ }^{21}$ Disponível em http://secretariageral.gov.br/atuacao/juventude/secretaria-nacional-dejuventude/historico

${ }^{22}$ O Projovem Urbano teve o caráter de intervenção emergencial, destinada a atender parcela significativa dos jovens com o perfil socioeconômico tipificado como público-alvo, que têm necessidade de retomar a trajetória escolar e prosseguir nos estudos (Manual do educador do Projovem)
} 
explica que como base o artigo 81 da LDB, o Programa foi aprovado como experiência dirigida à parcela da juventude diagnosticadamente mais afetada pelos processos de exclusão econômica e social.

Dessa forma, o Projovem viabilizou, por meio dos sistemas de educação, a certificação de conclusão do ensino fundamental e a qualificação profissional (formação inicial). (MEC/SECADI/Manual do Educador Orientações Gerais, 2012). Ainda em 2005 foi criado também o Conselho Nacional da Juventude - CNJ e a Secretaria Nacional de Juventude -SNJ.

O Programa foi implementado de forma gradual nos Estados, no Distrito Federal e nos Municípios, mediante a aceitação das condições estabelecidas no Decreto no 6.628 e mediante a assinatura de termo de adesão da Secretaria - Geral da Presidência da República. (MEC/SECADI/Manual do Educador Orientações Gerais, 2012).

A meta do Programa, inicialmente, era de atender a cerca de 200.000 jovens, que não haviam concluído o ensino fundamental, com idades entre 18 e 24 anos, no período de 2005 a 2008, atuando em todas as capitais brasileiras e no Distrito Federal. Em 2006 ampliouse $o$ atendimento aos municípios das regiões metropolitanas que possuíam 200.000 habitantes ou mais, tendo havido a adesão de 29 cidades. (MEC/SECADI/Manual do Educador Orientações Gerais, 2012).

O Programa original tinha como objetivo reintegrar os jovens à escola, oferecendoIhes qualificação profissional e acesso a ações de cidadania, esporte, cultura e lazer. $\mathrm{O}$ programa integrava o ensino fundamental, a qualificação profissional e ação comunitária pautada na formulação de um currículo que envolvesse teoria e prática objetivando atingir as seguintes dimensões curriculares:

- A Formação Básica deverá garantir as aprendizagens que correspondem às Diretrizes Curriculares Nacionais para o ensino fundamental e a certificação correspondente e, ao mesmo tempo, fundamentar a Qualificação Profissional e a Participação Cidadã.

- A Qualificação Profissional inicial deverá possibilitar novas formas de inserção produtiva, com a devida certificação, correspondendo, na medida do possível, tanto às necessidades e potencialidades econômicas, locais e regionais, quanto às vocações dos jovens.

- A Participação Cidadã deverá garantir aprendizagens sobre direitos sociais, promover o desenvolvimento de uma ação comunitária e a formação de valores solidários (MEC/SECADI/Manual do Educador Orientações Gerais, 2012, p. 37).

O curso tinha duração de 12 meses ininterruptos, Schmidt et. al., (2010, p. 09) menciona sobre o total de horas/aulas:

O curso totalizou 1.600 horas/aula divididas entre: formação escolar (800 horas), qualificação profissional (350 horas), desenvolvimento de ação comunitária (50 horas) e 400 horas de atividades não presenciais. $O$ currículo foi proposto de maneira integrada na qual a formação deveria ser planejada em caráter multidisciplinar, unindo o trabalho realizado em salas de aulas, oficinas, laboratórios, e campo de estágio, entre outros. A estrutura pedagógica, unificada em um Plano Pedagógico Integrado (PPI), contemplava quatro Unidades Formativas, com a duração de três meses cada sobre os temas: (I) Juventude e Cidade; (II) Juventude e Trabalho; (III) Juventude e Comunicação e (IV) Juventude e Cidadania. Todo material didático e exames foram elaborados exclusivamente para o programa. 
Havendo a frequência igual ou superior a $75 \%$ das aulas e a entrega dos trabalhos solicitados pelos professores, os estudantes receberiam uma bolsa de $R \$ 100,00$ (cem reais) por mês, limitadas a 12 meses.

As aulas eram ministradas em Núcleos (escolas), que funcionavam em locais selecionados pela infraestrutura oferecida e pela proximidade dos domicílios dos estudantes inscritos. Em cada Núcleo funcionavam cinco turmas, cada uma com no máximo 30 estudantes. Os Núcleos estavam vinculados à Estação Juventude, local que serviria como ponto de encontro para estudantes, busca de informação e orientação, desenvolvimento de atividades em grupo, realização de eventos culturais e, além disso, continha acervo multimídia e equipamentos que complementavam os trabalhos realizados nos Núcleos. Cada Estação Juventude era composta de oito Núcleos. (Schmidt et. al., 2010)

A figura a seguir ilustra a logística de formação dos Núcleos e Estações Juventude.

Figura 5: Estrutura de formação dos núcleos e Estações Juventude do Projovem

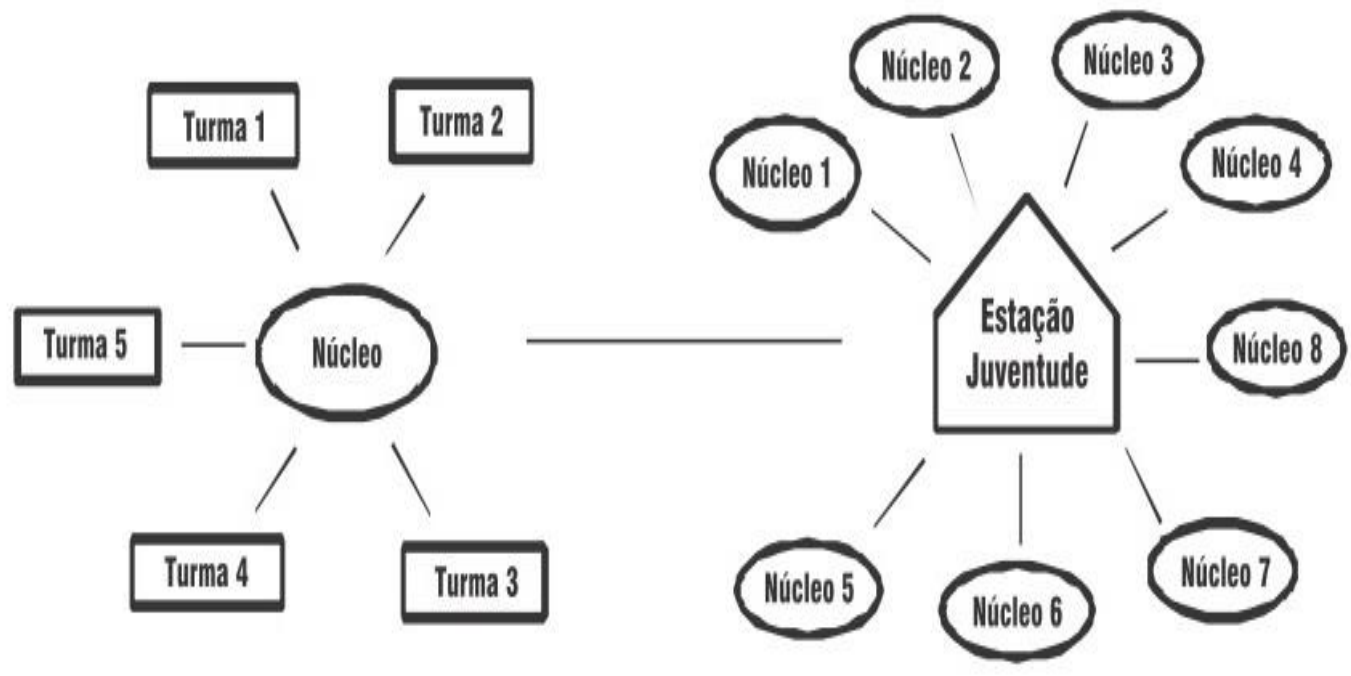

Fonte: Schmidt et. al. (2010, p. 09)

Com relação à qualificação profissional os estudantes do Projovem tinham a oportunidade de utilizarem os arcos ocupacionais, que tinham a finalidade de oferecer aprendizado de uma qualificação profissional, os arcos ocupacionais, em geral, deveriam ser desenvolvidos de acordo com as necessidades locais a fim de que os estudantes pudessem conhecer, aprender e posteriormente ingressar no mercado de trabalho. (Lucena e Silva, sd).

Segundo as autoras:

Os arcos ocupacionais fazem parte de uma das etapas mais importantes do Projovem, pois permitem que os estudantes passem a conhecer as oportunidades de atuar no mercado de trabalho seja 
como empregados, pequenos empresários ou integrantes de cooperativas. Os estudantes ao participarem dos arcos ocupacionais desenvolvem um entendimento sobre a produção e a circulação de bens e serviços no mercado de trabalho. É possível perceber pela estruturação do Projovem que esse programa oferece oportunidade para os jovens terem, além da oportunidade de reingresso a educação, acesso a uma nova possibilidade de exercerem o trabalho e a cidadania vislumbrando o crescimento pessoal tanto no âmbito de uma formação profissional como também no desenvolvimento de uma visão critica sobre a realidade social em que vive. (LUCENA E SILVA, s/d, p. 05/06)

Quadro dos arcos ocupacionais em 2005:

Quadro 1: Arcos Ocupacionais 2005

\begin{tabular}{|c|c|}
\hline ARCOS OCUPACIONAIS & OCUPAÇÕES \\
\hline 1. Administração & $\begin{array}{ll}- & \text { Arquivador } \\
- & \text { Almoxarife } \\
- & \text { Contínuo (Office-boy/Girl } \\
- & \text { Auxiliar Administrativo } \\
\end{array}$ \\
\hline 2. Agroextrativismo & $\begin{array}{ll}- & \text { Trabalhador em cultivo regional } \\
\text { - } & \text { Extrativista florestal de produtos regionais } \\
\text { - } & \text { Criador de pequenos animais } \\
\text { - } & \text { Artesão regional }\end{array}$ \\
\hline 3. Alimentação & $\begin{array}{ll}- & \text { Chapista } \\
- & \text { Cozinheiro auxiliar } \\
- & \text { Repositor de mercadorias } \\
& \text { Vendedor ambulante (alimentação) }\end{array}$ \\
\hline 4. Arte e Cultura I & $\begin{array}{ll}\text { - } & \text { Assistente de produção cultural } \\
\text { - } & \text { Auxiliar de cenotecnia } \\
\text { - } & \text { Assistente figurino } \\
\text { - } & \text { Dj/Mc }\end{array}$ \\
\hline 5. Arte e Cultura II & $\begin{array}{ll}\text { - } & \text { Revelador de filmes fotográficos } \\
\text { - } & \text { Fotográfo social } \\
\text { - } & \text { Operador de câmera de vídeo - cameraman } \\
& \text { Finalizador de vídeo } \\
\end{array}$ \\
\hline $\begin{array}{l}\text { 6. Construção e Reparos I } \\
\text { (revestimentos) }\end{array}$ & $\begin{array}{ll} & \text { Ladrilheiro } \\
- & \text { Gesseiro } \\
\text { - } & \text { Pintor } \\
\text { - } & \text { Reparador (revestimento) } \\
\end{array}$ \\
\hline $\begin{array}{l}\text { 7. Construção e reparos II } \\
\text { (instalações) }\end{array}$ & $\begin{array}{ll}- & \text { Eletricista de instalações (Edifícios) } \\
\text { - } & \text { Trabalhador da manutenção de edificações } \\
\text { - } & \text { Instalador-reparador de linhas e aparelhos de } \\
\text { - } & \text { telecomunicações } \\
\text { Instalador de sistemas eletrônicos de } \\
\text { segurança }\end{array}$ \\
\hline 8. Educação & $\begin{array}{ll}- & \text { Auxiliar de administração escolar } \\
\text { - } & \text { Contador de histórias } \\
\text { - } & \text { Inspetor de estudantes } \\
\text { - } & \text { Recreador } \\
\end{array}$ \\
\hline 9. Esporte e lazer & $\begin{array}{ll}- & \text { Recreador } \\
- & \text { Agente comunitário de esporte e lazer } \\
\text { - } & \text { Monitor de esporte e lazer } \\
\text { - } & \text { Animador de eventos }\end{array}$ \\
\hline $\begin{array}{l}\text { 10. Gestão Pública e Terceiro } \\
\text { Setor }\end{array}$ & $\begin{array}{ll}- & \text { Agente comunitário } \\
- & \text { Agente de projetos sociais } \\
\text { - } & \text { Coletor de dados de pesquisas e informações }\end{array}$ \\
\hline
\end{tabular}




\begin{tabular}{|c|c|}
\hline & locais \\
\hline & Auxiliar administrativo \\
\hline 11. Gráfica & $\begin{array}{ll} & \text { Guihotineiro (Indústira gráfica) } \\
- & \text { Impressor serigráfico } \\
- & \text { Operador de acabamento ( Indústria gráfica) } \\
\text { - } & \text { Encanador }\end{array}$ \\
\hline 12. Joalheria & $\begin{array}{ll}- & \text { Ourives na fabricação e reparação de jóias } \\
- & \text { Fundidor } \\
- & \text { Auxiliar na confecção de bijuterias } \\
\text { - } & \text { Vendedor de comércio (Jóias, bijuterias e } \\
& \text { adereços) }\end{array}$ \\
\hline 13. Madeira e Móveis & $\begin{array}{ll}- & \text { Marceneiro } \\
- & \text { Reformador de móveis } \\
- & \text { Auxiliar de desenhista de móveis } \\
\text { - } & \text { Vendedor de móveis }\end{array}$ \\
\hline 14. Metalmecânica & $\begin{array}{ll}\text { - } & \text { Serralheiro } \\
- & \text { Funileiro industrial } \\
- & \text { Auxiliar de promoção de vendas } \\
\text { - } & \text { Assistente de vendas (automóveis e } \\
& \text { autopeças) }\end{array}$ \\
\hline 15. Pesca e Psicultura & $\begin{array}{ll}- & \text { Trabalhador na pesca artesanal } \\
- & \text { Trabalhador na psicultura } \\
\text { - } & \text { Trabalhador em unidades de beneficiamento e } \\
& \text { processamento de pescador } \\
\text { - } & \text { Vendedor de pescados }\end{array}$ \\
\hline 16. Saúde & $\begin{array}{l}\text { - } \quad \text { Auxiliar de administração em hospitais e } \\
\text { - } \quad \text { clínicas } \\
\text { - } \\
\text { - } \\
\text { Recepcionista de consultório médico e dentário } \\
\text { Atendente de laboratório de análises clínicas } \\
\text { Atende de farmácia - balconista }\end{array}$ \\
\hline 17. Serviços Domésticos I & $\begin{array}{ll}- & \text { Faxineira } \\
- & \text { Porteiro } \\
- & \text { Cozinheira no serviço doméstico } \\
& \text { Caseiro } \\
\end{array}$ \\
\hline 18. Serviços Domésticos II & $\begin{array}{ll}- & \text { Cuidador de idosos } \\
- & \text { Passador de roupas } \\
- & \text { Cuidador de crianças (babá) } \\
& \text { Lavadeiro } \\
\end{array}$ \\
\hline 19. Serviços Pessoais & $\begin{array}{ll}- & \text { Manicura e pedicura } \\
- & \text { Depilador } \\
- & \text { Cabeleireiro } \\
- & \text { Maquiador } \\
\end{array}$ \\
\hline 20. Telemática & $\begin{array}{ll}- & \text { Operador de microcomputador } \\
\bullet & \text { Helpdesk } \\
\bullet & \text { Telemarketing (vendas) } \\
- & \text { Assistente de vendas (informática e celulares) }\end{array}$ \\
\hline 21. Transporte & $\begin{array}{ll}- & \text { Cobrador de transportes coletivos } \\
- & \text { Despachante de tráfego } \\
- & \text { Assistente administrativo } \\
\text { - } & \text { Ajudante geral em transportes } \\
\end{array}$ \\
\hline 22. Turismo e Hospitalidade & $\begin{array}{ll}- & \text { Organizador de eventos } \\
- & \text { Cumim (auxiliar de garçon) } \\
- & \text { Recepcionista de hotéis } \\
\text { - } & \text { Monitor de turismo local }\end{array}$ \\
\hline
\end{tabular}

Fonte: Lucena e Silva (sd)

Desta forma, o Programa original pretendia contribuir para que o jovem voltasse a 
frequentar a escola; ampliar a capacitação profissional e auxiliar na sua inserção ou reinserção no mercado de trabalho, ajudando-os a identificar possibilidades de intervenção na vida comunitária. (Schmidt et. al., 2010).

O ProJovem original também se organizou em cinco sistemas integrados, que tinham como objetivo garantir a execução do curso em todos os níveis organizacionais previstos nas diretrizes do programa, quais foram:1) Sistema Instrucional: responsável pela organização do material pedagógico, para dar sustentação ao processo de ensino e aprendizagem; 2) Sistema Operacional; 3) Sistema de Apoio Pedagógico ao Estudante; 4) Sistema de Comunicação e Informação; e 5) Sistema de Monitoramento e Avaliação do Programa. (Schmidt et. al., 2010)

O programa contou ainda com Comitê Gestor coordenado pela Secretaria-Geral da Presidência da República, integrado pelo Ministério da Educação, pelo Ministério do Trabalho e Emprego e pelo Ministério do Desenvolvimento Social e Combate à Fome. O braço local de operacionalização nas capitais foram as prefeituras e o governo do Distrito Federal. Outras instituições ou organizações puderam apoiar e se integrar ao programa, mas tal articulação ficou a cargo das coordenações locais. (Schmidt et. al., 2010)

O Projovem, a fim de implementar suas atividades e iniciar sua avaliação externa ao mesmo tempo, agrupou várias instituições de ensino superior, o que era uma inovação até então, de acordo com Schmidt et. al., (2010, p. 10): "o Sistema de Monitoramento e Avaliação (SMA) mostrou-se uma experiência promissora e capaz de reunir diferentes expertises em torno de um mesmo tema."

O SMA foi estabelecido a fim de cumprir o disposto na Lei $\mathrm{n}^{\circ} 11.129$, de 30 de junho de 2005 em seu Art 1, que trata da avaliação da qualidade do programa: " $\$ 1^{\circ} 0$ ProJovem terá validade pelo prazo de 2 (dois) anos, devendo ser avaliado ao término do $2^{\circ}$ (segundo) ano, com o objetivo de assegurar a qualidade do Programa." O SMA oferecia subsídios para gestão e aperfeiçoamento do programa, o monitoramento e avaliação eram feitos pelas universidades através de supervisores, que realizavam visitas aos núcleos para verificar seu funcionamento e aplicavam questionários aos professores e aos estudantes. Os questionários continham perguntas referentes à infraestrutura, localização da escola e à parte pedagógica. Sendo que todas essas informações eram inseridas no sistema do Centro de Políticas Públicas e Avaliação da Educação - CAED, que era responsável por analisar os dados. As visitas dos supervisores eram realizadas no inicio de cada unidade formativa, também eram realizadas visitas nas estações juventude nas quais os supervisores eram os responsáveis pelo preenchimento dos questionários

Em 2005, foram concebidos dois subsistemas: um externo, gerenciado por uma instituição de ensino superior que coordenaria o trabalho de outras instituições, responsável pelo monitoramento e avaliação do programa; e um interno, coordenado por outra instituição de ensino superior que seria responsável pelo monitoramento dos dados escolares, de frequência e de gestão do programa (Schmidt et. al., 2010). E o objetivo era produzir dados, informações e conhecimentos que permitissem: o monitoramento da implementação; a avaliação do programa; e a avaliação da qualidade do curso em termos pedagógicos. 
Schmidt et. al., (2010, p. 10/11) explicam que à medida que os trabalhos começaram e as instituições conveniadas foram agrupadas, a dinâmica de trabalho mudou e a coordenação nacional do programa optou pelo estabelecimento de quatro subsistemas, quais sejam:

1. Subsistema de monitoramento: responsável pela produção de informações necessárias à gestão do programa em diferentes níveis, como por exemplo: monitoramento do cadastro e da matrícula de estudantes; formação e alocação de educadores e coordenadores; registro de frequências; e ações curriculares. Este subsistema era igualmente responsável pelas informações repassadas à instituição financeira para pagamento do benefício aos estudantes.

2. Subsistema de supervisão: responsável pela inspeção de núcleos, estações juventude e agências formadoras com o objetivo de verificar a implementação das diretrizes do programa.

3. Subsistema de avaliação externa de estudantes: responsável por elaborar instrumentos de avaliação pedagógica externa da formação dos estudantes além de realizar a avaliação dos resultados de desempenho pedagógico.

4. Subsistema de avaliação do programa: responsável pelas pesquisas de avaliação da implementação e da efetividade do ProJovem. Diante do número de cidades participantes, inicialmente em todas as capitais brasileiras e Distrito Federal, e no segundo ano cidades das regiões metropolitanas com mais de 200 mil habitantes, a coordenação nacional do programa decidiu celebrar convênio com sete instituições universitárias, denominadas Instituições Regionais (IR).

As Instituições Regionais (IR) Participantes do SMA, Seus Estados e Cidades eram:

Quadro 2: Instituições Regionais

\begin{tabular}{|c|c|c|c|}
\hline Instituição & Regional & Estados & Cidades \\
\hline $\begin{array}{c}\text { Universidade de } \\
\text { Brasília - UNB }\end{array}$ & $\begin{array}{c}\text { Centro - } \\
\text { Oeste }\end{array}$ & $\begin{array}{c}\text { Distrito Federal, Goiás, } \\
\text { Mato Grosso e Mato } \\
\text { Grosso do Sul. }\end{array}$ & $\begin{array}{c}\text { Aparecida de Goiânia, } \\
\text { Brasília, Campo Grande, } \\
\text { Cuiabá, Goiânia e Palmas. }\end{array}$ \\
\hline $\begin{array}{c}\text { Universidade } \\
\text { Federal da } \\
\text { Bahia - UFBA }\end{array}$ & Nordeste 1 & $\begin{array}{c}\text { Alagoas, Bahia, Piaú, } \\
\text { Sergipe e Maranhão. }\end{array}$ & $\begin{array}{c}\text { Aracajú, Maceió, Salvador, } \\
\text { São Luiz e Teresina. }\end{array}$ \\
\hline $\begin{array}{c}\text { Universidade } \\
\text { Federal de } \\
\text { Pernambuco }- \\
\text { UFPE }\end{array}$ & Nordeste 2 & $\begin{array}{c}\text { Ceará, Paraíba, } \\
\text { Pernambuco e Rio } \\
\text { Grande do Norte. }\end{array}$ & $\begin{array}{c}\text { Fortaleza, João Pessoa, } \\
\text { Natal, Recife, Olinda, } \\
\text { Paulista, Jaboatão dos } \\
\text { Guararapes e Caucaia. }\end{array}$ \\
\hline $\begin{array}{c}\text { Universidade } \\
\text { Federal do Pará } \\
- \text { UFPA }\end{array}$ & Norte & $\begin{array}{c}\text { Acre, Amapá, } \\
\text { Amazonas, Pará, } \\
\text { Rondônia e Roraima. }\end{array}$ & $\begin{array}{c}\text { Ananindeua, Belém, Boa } \\
\text { Vista, Macapá, Manaus, } \\
\text { Porto Velho e Rio Branco. }\end{array}$ \\
\hline $\begin{array}{c}\text { Universidade } \\
\text { Federal de Juiz } \\
\text { de Fora - UFJF }\end{array}$ & Sudeste 1 & São Paulo. & $\begin{array}{c}\text { São Paulo, Carapicuíba, } \\
\text { Diadema, Embu das Artes, } \\
\text { Guarulhos, } \\
\text { Itaquaquecetuba, Mogi das } \\
\text { Cruzes, Osasco, Santo } \\
\text { André e Suzano. }\end{array}$ \\
\hline
\end{tabular}




\begin{tabular}{|c|c|c|c|}
\hline $\begin{array}{l}\text { Universidade } \\
\text { Federal de } \\
\text { Minas Gerais - } \\
\text { UFMG }\end{array}$ & Sudeste 2 & $\begin{array}{l}\text { Espírito Santo, Minas } \\
\text { Gerais e Rio de Janeiro. }\end{array}$ & $\begin{array}{l}\text { Belo Horizonte, Contagem, } \\
\text { Vitória, Serra, Vila Velha, } \\
\text { Rio de Janeiro, Belford } \\
\text { Roxo, Duque de Caxias, } \\
\text { Magé, Niterói, Nova Iguaçu } \\
\text { e São João de Meriti. }\end{array}$ \\
\hline $\begin{array}{l}\text { Universidade } \\
\text { Federal do } \\
\text { Paraná - UFPR }\end{array}$ & Sul & $\begin{array}{l}\text { Paraná, Rio Grande do } \\
\text { Sul e Santa Catarina. }\end{array}$ & $\begin{array}{c}\text { Curitiba, Florianópolis, } \\
\text { Porto Alegre, Viamão, Novo } \\
\text { Hamburgo, Gravataí e } \\
\text { Canoas. }\end{array}$ \\
\hline
\end{tabular}

Fonte: Relatório final do ProJovem Original, 2005-2008. Brasil, 2010, Apud Schmidt et. al., (2010)

Schmidt et. al., (2010) mencionam que delimitadas as linhas de ação e estabelecidos os convênios, as IR se dividiram nos grupos de trabalho (GT) e deram início às atividades. Ao longo do tempo os GT tiveram diferentes composições. Além dos subsistemas, a Coordenação Nacional do ProJovem instituiu o Conselho Técnico como instância deliberativa para as decisões tomadas nos grupos de trabalho dos diferentes subsistemas. O Conselho Técnico era formado pela coordenadora nacional do ProJovem e por todos os coordenadores de IR.

Através do Sistema de Monitoramento e Avaliação (SMA) muito se pôde conhecer sobre o perfil do jovem brasileiro atendido pelo Programa e atuando em parceria com a Coordenação Nacional, esse grupo acompanhou o processo e os resultados do Programa, no período de 2005 a 2011, oferecendo subsídios para sua gestão e aperfeiçoamento. (MEC/SECADI/Manual do Educador Orientações Gerais, 2012).

A partir disso, em 10 de junho de 2008, a Medida Provisória no 411/ 2007 foi convertida na Lei ํo 11.692/2008 (anexo 4), que dispõe sobre o Programa de Inclusão de Jovens - Projovem e determina, em seu art. 20: "O Projovem, destinado a jovens de 15 a 29 anos, com o objetivo de promover sua reintegração ao processo educacional, sua qualificação profissional e seu desenvolvimento humano, será desenvolvido por meio das modalidades: (I) Projovem Adolescente - Serviço Socioeducativo; (II) Projovem Urbano; (III) Projovem Campo Saberes da Terra; e (IV) Projovem Trabalhador".

\subsection{Projovem Urbano a partir de 2008}

Com o trabalho realizado pelo SMA foi constatado que havia a necessidade de algumas mudanças no Programa a partir das suas pesquisas de caráter qualitativo e quantitativo, assim, o Programa sofreu, em 2008, alterações de formato e mudou seu nome para Projovem Urbano, mas manteve os objetivos propostos inicialmente (Nascimento, 2013). Essa mudança foi apreciada pelo Conselho Nacional de Educação, por meio do Parecer

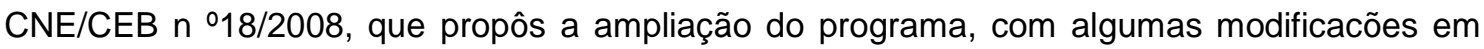
sua estrutura.

As mudanças mais significativas foram a ampliação da meta inicial de 200.000 (de 2005 a 2008) para 4 milhões de jovens (de 2008 a 2010); o ingresso do Jovem no programa 
por matrículas online realizadas localmente e a permanência passando a um período de 18 meses; a ampliação da faixa etária, indo de 18 a 29 anos; a possibilidade de o jovem já poder estar inserido no mercado formal de trabalho; a não exigência da conclusão da quarta série do ensino fundamental, podendo o jovem ter tido acesso apenas a alfabetização ou séries iniciais; a parte prática da Qualificação Profissional iniciar-se conjuntamente com a FTG - Formação Técnica Geral desde a primeira UF - Unidade Formativa; o formato da execução financeira que não mais teria o repasse de recursos através de convênio celebrado entre as partes e adoção do modelo de transferência de recursos per capita, o que interferiu, consequentemente, na gestão do programa; a implantação dos Pólos, para cada 2.400 jovens, no lugar das Estações Juventude, bem como a mudança na Coordenação Municipal, composta pelo Coordenador Executivo e Coordenador Pedagógico, não tendo mais os coordenadores de Qualificação Profissional e de Ação Comunitária; a mudança da dimensão de Ação Comunitária para Participação Cidadã; ampliação de 07 para 10 Universidades Federais que, juntamente com a Universidade Federal de Juiz de Fora, através do CAED - Centro de Avaliação da Educação passaram a fazer o Sistema de Monitoramento e Avaliação - SMA; ampliação da matriz curricular a partir dos Eixos Estruturantes Juventude e Cultura e Juventude e tecnologia; a apresentação de uma modelo de gestão inter-setorial, compartilhada entre quatro ministérios, e de implantação em regime de cooperação com os Estados, Municípios e Distrito, envolvidos; a carga horária passando a ser de 2.000 horas, sendo 1.560 presenciais e 440 não presenciais; a oferta, a partir da Coordenação nacional e a FUNDAR - Fundação Darcy Ribeiro, de formação continuada para os gestores escolares; a obrigatoriedade de ter as atividades pedagógicas desenvolvidas em escolas públicas (Lira et al,sd).

\subsection{Projovem Urbano - Ministério da Educação}

Em 2012, o Projovem Urbano deixou o SNJ e começou a ser coordenado nacionalmente pelo Ministério da Educação, com sua gestão sendo centrada no MEC e nas Secretarias Estaduais e/ou Municipais de Educação. Essa transição buscou elevar a escolarização de jovens e adultos, com um projeto pedagógico elaborado pelo CNE que intencionou que o jovem pudesse ser certificado pela rede pública e que o Programa pudesse ser considerado uma ação dentro da modalidade de jovens e adultos. Quando o programa passou a ser coordenado pelo MEC o aluno passou a integrar o sistema de ensino e a ter todas as prerrogativas do aluno da rede pública, passando a compor o censo escolar, tendo visibilidade dentro das estatísticas de elevação de escolaridade da população brasileira e da distribuição de recursos, como por exemplo, a alimentação escolar. Essa transição buscou garantir a atualização, o aperfeiçoamento e a expansão do programa, tendo o objetivo permanecido o mesmo:

Elevar a escolaridade de jovens com idade entre 18 e 29 anos, que saibam ler e escrever e não tenham concluído o ensino fundamental, visando à conclusão desta etapa por meio da modalidade de Educação de Jovens e Adultos integrada à qualificação profissional e - desenvolvimento de ações comunitárias com exercício da cidadania, na forma de curso, conforme previsto no art. 81 da Lei $n$. 
9.394, de 20 de dezembro de 1996. (NOTA TÉCNICA № 02 / 2012 /

MEC / SECADI / PROJOVEM URBANO)

Ainda em 2012 o Projovem Urbano ${ }^{23}$ foi vinculado à estrutura do sistema educacional brasileiro e passou a ser compreendido como uma modalidade da Educação de Jovens e Adultos, vinculada à Secretaria de Educação Continuada, Alfabetização, Diversidade e Inclusão (SECADI) do MEC.

O Programa em 2012 reiterou a finalidade geral das versões anteriores proporcionar formação integral aos jovens por meio de um conjunto de diretrizes: as diretrizes operacionais (Detalhadas no anexo 2) e das diretrizes gerais que são:

a) Formação Básica, para elevação da escolaridade, tendo em vista a conclusão do Ensino Fundamental/EJA;

b) Qualificação Profissional, com a certificação de formação inicial, levandose em conta as potencialidades econômicas locais e regionais, bem como a vocação do jovem;

c) Participação Cidadã ${ }^{44}$, com a promoção de experiência de atuação social na comunidade. (SGPR/SNJ/MEC/SECADI, 2012)

O programa assumiu como sendo suas finalidades:

a) A reinserção dos jovens no processo de escolarização;

b) A identificação de oportunidades potenciais de trabalho e a capacitação dos jovens para o mundo do trabalho;

c) A participação dos jovens em ações coletivas de interesse público;

d) A inclusão digital como instrumento de inserção produtiva e de comunicação; e a ampliação do acesso dos jovens à cultura. (Chagas e Posselt, 2013).

Já no MEC, cinco pontos do Programa foram trabalhados:

a) O público-alvo;

b) Ampliação da base territorial;

c) Divulgação e democratização de acesso;

d) Novas estruturas de gestão de local e;

e) O novo esquema de qualificação profissional.

O currículo do Projovem Urbano foi criado com o propósito de aliar teoria e prática, formação e ação, explorando a dimensão educativa tanto do trabalho como da participação

\footnotetext{
${ }^{23}$ Além do Projovem Urbano, há, ainda, três outras modalidades do Projovem, mas como o objetivo do trabalho não é discorrer sobre todas elas, essa explanação foi colocada como o anexo número 3.

${ }^{24}$ A Participação Cidadã é uma dimensão essencial do currículo integrado, permitindo a realização de trabalhos coletivos e associados a outros componentes curriculares. No desenvolvimento dessa dimensão curricular, os jovens aprendem a avaliar o alcance de suas ações, as formas de encaminhamento das demandas dos cidadãos/grupos sociais e os meios de resposta possíveis, sendo levados a compreender a importância e a eficácia do trabalho coletivo e solidário e tudo que isso pode representar em termos de aprendizado e desenvolvimento de competências e habilidades, visando à participação social e ao exercício da cidadania. Envolve aulas teórico-práticas e a elaboração/implementação/avaliação de um projeto de intervenção na comunidade em que vivem, o Plano de Ação Comunitária - PLA. (SGPR/SNJ/MEC/SECADI, 2012)
} 
cidadã, sendo que o público-alvo do programa, a partir de 2012, teve como base de estudos os dados da PDAD de 2009, naquela época a população de jovens no Brasil era de 39.507.663 pessoas na faixa etária de 18 a 29 anos, das quais $9.294 .905(23,5 \%)$ não possuíam instrução ou Ensino Fundamental completo. Os negros nessa época eram 6.347 .095 (69,4\%) e a população no campo chegava a 2.777.983. Outro dado utilizado foi do IBGE de 2010 que apresentava pouca variação desses dados e apontava uma população total de 40.982.599, na faixa etária de 18 a 29 anos. O público-alvo do Projovem Urbano é constituído por esses jovens de 18 a 29 de anos que sabem ler e escrever e que não concluíram o Ensino Fundamental. E para subsidiar a definição das metas de atendimento para 2012, a SECADI solicitou ao Instituto de Pesquisa Econômica Aplicada - IPEA - uma estimativa da população de 18 a 29 anos, com 1 a 7 anos de estudo, por cor/ raça, para cada município brasileiro. O IPEA calculou para cada unidade da federação os valores pretendidos, utilizando, como base de cálculo, o número de jovens do Censo 2010 e as proporções da PNAD 2009. (SGPR/SNJ/MEC/SECADI, 2012)

De acordo com o estudo, as metas possíveis do Projovem Urbano para 2012, tinham correspondência de apenas $2 \%$ dessa população. Isso reforçou a ideia de que as ofertas educacionais eram insuficientes para o público alvo, cuja dependência em relação a políticas específicas ficou evidenciada nas pesquisas do Sistema de Monitoramento e Avaliação - SMA. Com base nelas, pode-se afirmar que os jovens considerados não tiveram, anteriormente, oportunidades educacionais adequadas nem chances de preparar-se para os desafios do mundo do trabalho. Com a transferência para o MEC, o estudante do Projovem Urbano, passou a ser contabilizado no Censo Escolar/INEP, o que tornou a gestão do Programa parte integrante da gestão da escola pública e facilitou o atendimento das metas. (SGPR/SNJ/MEC/SECADI, 2012)

Com relação à base territorial do Projovem Urbano esta foi ampliada, possibilitando a adesão dos municípios com população de 100.000 habitantes ou mais e permitiu que os estados atendessem àqueles com população inferior a esse número de habitantes. Essa ampliação territorial permitiu o alcance pelo Programa de muitos jovens moradores de municípios menores que nunca tiveram oportunidade de participar de uma política pública especialmente pensada para eles. Para a entrada de 2012, aderiram ao programa 123 municípios, 17 estados e o Distrito Federal. A condição para que os municípios parceiros iniciem suas atividades foi a existência de pelo menos um Núcleo com 200 estudantes. (SGPR/SNJ/MEC/SECADI, 2012)

Um dos grandes desafios para garantir o sucesso do Projovem Urbano foi quanto à divulgação e democratização do acesso às vagas disponíveis em cada município, pois uma das regras é que todos os jovens com o perfil do público-alvo tenham acesso às informações sobre o Programa e encontrem condições igualitárias e transparentes para inscrever-se e garantir seu ingresso. De acordo como o Manual do Educador do Projovem (2012), a dispersão geográfica do público alvo potencial requer ações efetivas não só para identificar os jovens a serem atendidos, mas também para acompanhar esses jovens durante todo o tempo de formação além de buscar a permanência deles no curso. 
A avaliação do Programa, ainda de acordo com o Manual do Educador (2012), teve resultados melhores quanto a sua divulgação, quando as ações de mobilização foram desenvolvidas pelos municípios e estados parceiros, sendo que as secretarias e seus órgãos regionais foram orientados a planejar um esquema de ação próprio para informar aos jovens de sua localidade sobre a oferta do Programa. Assim sendo, as matrículas dos estudantes passaram a ser feitas diretamente nas escolas públicas selecionadas, que haviam sido escolhidas pelos Estados, Municípios, e pelo Distrito Federal, para desenvolver o curso.

Houve ainda alterações quanto às estruturas de gestão local: a coordenação local do Programa passou a ser composta por um Coordenador Geral, um Assistente Administrativo e um Assistente Pedagógico, e ficou diretamente vinculada ao departamento de Educação de Jovens e Adultos das secretarias de educação (municipais, estaduais e do Distrito Federal).

Quanto ao espaço pedagógico o Projovem está estruturado em Núcleos que são a unidade de organização pedagógica básica, funcionando nas escolas das redes publicas selecionadas pelo Distrito Federal, Municípios ou pelos Estados. Os Núcleos são como um espaço pedagógico constituído por cinco turmas e sete educadores, que ministram as disciplinas: ciências humanas, que são história e geografia; ciências da natureza que são física, química e biologia; língua portuguesa; inglês; matemática, profissional de participação cidadã e o educador prossional. Cada Núcleo pode funcionar em até duas unidades escolares e, quando necessário, o Núcleo dever ter um profissional tradutor e intérprete de Libras e um educador para atendimento educacional especializado. Os educadores de Qualificação Profissional e de Participação Cidadã são lotados em apenas um Núcleo, ampliando-se seu tempo de permanência nesse espaço, para melhor execução das atividades pedagógicas propostas. A estrutura dos núcleos é exemplificada a seguir.

Figura 6: Esquematização de um Núcleo

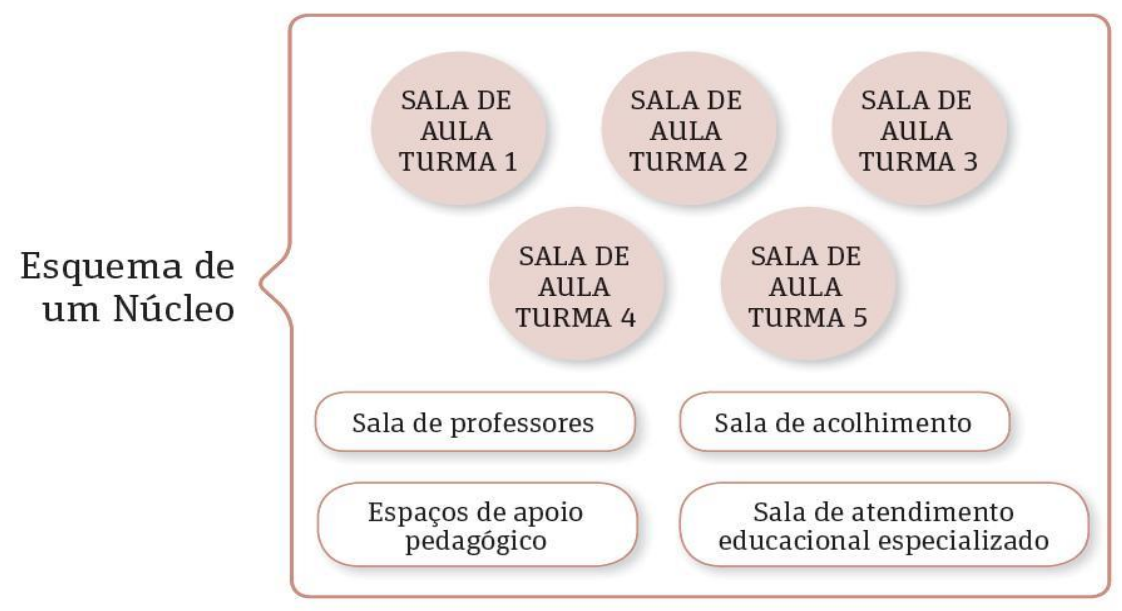

Fonte: (SGPR/SNJ/MEC/SECADI, 2012)

Os núcleos dão a formação dos pólos que são as unidades organizacionais do Projovem nos Municípios e nos Estados. 
Figura 7: Projovem Urbano nos Estados e Municípios

\section{PROJOVEM URBANO NOS MUNICÍPIOS E NOS ESTADOS}

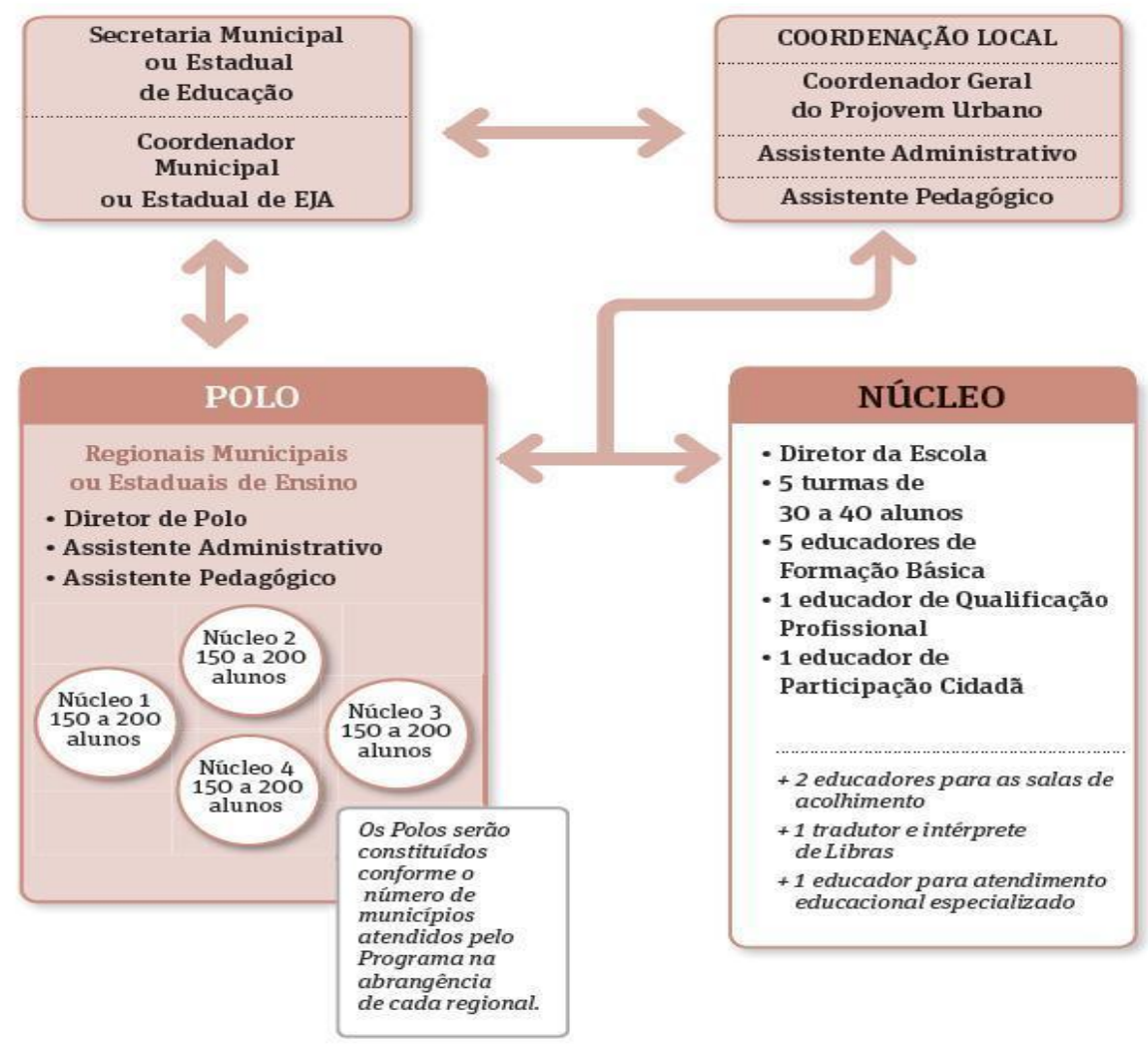

Fonte: (SGPR/SNJ/MEC/SECADI, 2012), adaptado pelo mestrando

\subsubsection{Da formação do estudante}

O estudante do Projovem, a fim de obter sua certificação, deve cumprir uma carga horária total de 2000 horas sendo 1440 presenciais, distribuídas em 1008 horas de formação básica, 360 de qualificação profissional e 72 de participação cidadã e mais 560 horas não presenciais, ao longo de um período de 18 meses ou 72 semanas, distribuídas em 6 Unidades Formativas.

No que tange a Qualificação Profissional ${ }^{25}$ esta é composta pela Formação Técnica Geral - FTG ${ }^{26}$, pela Formação Técnica Específica - $\mathrm{FTE}^{27}$ e pelo Projeto de

${ }^{25}$ Qualificação Profissional: Oferece ao jovem uma formação inicial capaz de desenvolver suas aptidões profissionais proporcionando-lhe novas oportunidades e escolhas no mundo do trabalho. (Chagas e Posselt, 2013)

26 Formação Técnica Geral (FTG), que aborda conhecimentos necessários a quaisquer atividades de trabalho e permite ao jovem compreender o papel do trabalho e da formação profissional no mundo contemporâneo. (SGPR/SNJ/MEC/SECADI, 2012)

${ }^{27}$ A Formação Técnica Específica (FTE) proporciona ao jovem a aprendizagem de conteúdos de uma ou mais ocupações, dependendo da estrutura da oferta em cada localidade. (SGPR/SNJ/MEC/SECADI, 2012) 
Orientação Profissional - $\mathrm{POP}^{28}$, houve uma remodelação das formações em 2012: a FTE poderá ser desenvolvida por meio dos Arcos Ocupacionais ou dos cursos de Formação Inicial e Continuada - FIC - do Programa Nacional de Acesso ao Ensino Técnico e Emprego PRONATEC 29 - naqueles estados ou municípios onde exista o desenvolvimento desse Programa e a oferta específica de cursos para os estudantes do Projovem Urbano. (SGPR/SNJ/MEC/SECADI, 2012).

Quadro 3: Componentes da Qualificação Profissional

\begin{tabular}{|c|c|c|c|c|c|c|}
\hline \multicolumn{7}{|c|}{ Qualificação Profissional - Componentes/Carga Horária do estudante } \\
\hline Componente & UF1 & UF2 & UF3 & UF4 & UF5 & UF6 \\
\hline FTG & $\begin{array}{c}5 \mathrm{~h} / \mathrm{sem}= \\
60 \mathrm{~h}\end{array}$ & $\begin{array}{c}5 \mathrm{~h} / \mathrm{sem}= \\
60 \mathrm{~h}\end{array}$ & & & & $\begin{array}{c}5 \mathrm{~h} / \mathrm{sem}= \\
60 \mathrm{~h}\end{array}$ \\
\hline FTE & & & $\begin{array}{c}5 \mathrm{~h} / \mathrm{sem}= \\
60 \mathrm{~h}\end{array}$ & $\begin{array}{c}5 \mathrm{~h} / \mathrm{sem}= \\
60 \mathrm{~h}\end{array}$ & $\begin{array}{c}5 \mathrm{~h} / \mathrm{sem}= \\
60 \mathrm{~h}\end{array}$ & \\
\hline POP & \multicolumn{6}{|c|}{ Acompanha o estudante em todo o processo formativo } \\
\hline \multicolumn{3}{|c|}{ FTG $=180$ horas } & \multicolumn{4}{|c|}{ FTE $=180$ HORAS } \\
\hline
\end{tabular}

Fonte: Chagas e Posselt (2013)

Além das horas em sala de aulas e das formações técnicas, acima citadas, a fim de que o estudante conclua o programa com sucesso, ele deve ter um Plano de Ação Comunitária - PLA, que é um plano elaborado, desenvolvido, avaliado e sistematizado ao longo do curso, no qual é inferida a ideia de participar e exercer a cidadania. A ideia é que nas aulas sejam discutidas questões sobre direitos humanos e do consumidor, acesso aos bens e serviços públicos, ética e cidadania, saneamento, saúde pública, serviços públicos, preservação do meio ambiente, violência, drogas, sexualidade, participação social, direito à cultura e ao lazer.

Ao longo do curso os diferentes instrumentos de certificação perfazem um total de 2200 pontos, sendo que para ser aprovado o estudante deve ter um rendimento de pelo menos $50 \%$ da pontuação total, e ter presença em pelo menos $75 \%$ das atividades presenciais (em um total de 1080 horas), cabendo ainda ao conselho de classe a decisão sobre a aprovação ou não dos estudantes que não atenderem a um dos requisitos acima citados.

Importante mencionar que a qualificação profissional é realizada por meio dos arcos ocupacionais. Cada município escolhe entre um e cinco arcos, de acordo com as necessidades locais do mercado de trabalho. Entre os setores de capacitação mais comuns estão os de Telemática; Madeiras e Móveis; Turismo; Construção e Reparo; Alimentação e Vestuário. (Projovem Urbano, s.d.).

Os Arcos ocupacionais a partir de 2012 foram assim distribuídos.

\footnotetext{
${ }^{28}$ Projeto de Orientação Profissional (POP) instrumento de integração da FTG com a FTE e delas com as demais dimensões do currículo. É uma reflexão individual continudada sobre todas as atividades curriculares. (SGPR/SNJ/MEC/SECADI, 2012)

${ }^{29}$ Programa Nacional de Acesso ao Ensino Técnico e Emprego, criado em 2011, com o objetivo de expandir, interiorizar e democratizar a oferta de cursos de educação profissional e tecnológica no país.
} 
Quadro 4: Arcos Ocupacionais 2012

\begin{tabular}{|c|c|}
\hline 1. Administração & $\begin{array}{l}\text { a. Arquivador b. Almoxarife c. Contínuo (Office-Boy/Office-Girl). } \\
\text { d.Auxiliar Administrativo }\end{array}$ \\
\hline 2. Agroextrativismo & $\begin{array}{l}\text { a. Trabalhador em Cultivo Regional b. Extrativista Florestal de } \\
\text { Produtos Regionais c. Criador de Pequenos Animais d. Artesão } \\
\text { Regional }\end{array}$ \\
\hline 3. Alimentação & $\begin{array}{l}\text { a. Chapista b. Cozinheiro Auxiliar c. Repositor de Mercadorias d. } \\
\text { Vendedor Ambulante (Alimentação). }\end{array}$ \\
\hline 4. Arte e Cultura I & $\begin{array}{l}\text { a. Assistente de Produção Cultural b. Auxiliar de Cenotecnia c. } \\
\text { Assistente de Figurino d. DJ/Mc }\end{array}$ \\
\hline 5. Arte e Cultura II & $\begin{array}{l}\text { a. Revelador de Filmes Fotográficos b. Fotógrafo Social c. } \\
\text { Operador de Câmera de Vídeo - Cameraman d. Finalizador de } \\
\text { Vídeo }\end{array}$ \\
\hline $\begin{array}{l}\text { 6. Construção e } \\
\text { Reparos I } \\
\text { (Revestimentos) }\end{array}$ & a. Ladrilheiro b. Gesseiro c. Pintor d. Reparador (Revestimento). \\
\hline $\begin{array}{l}\text { 7. Construção e } \\
\text { Reparos II } \\
\text { (Instalações) }\end{array}$ & $\begin{array}{l}\text { a. Eletricista de Instalações (Edifícios). b. Trabalhador da } \\
\text { Manutenção de Edificações c. Instalador-Reparador de Linhas e } \\
\text { Aparelhos de Telecomunicações d. Instalador de Sistemas } \\
\text { Eletrônicos de Segurança }\end{array}$ \\
\hline 8. Educação & $\begin{array}{l}\text { a. Auxiliar de Administração Escolar b. Contador de Histórias c. } \\
\text { Inspetor de estudantes d. Recreador }\end{array}$ \\
\hline $\begin{array}{l}\text { 9. Gestão Pública e } \\
\text { Terceiro Setor }\end{array}$ & $\begin{array}{l}\text { a. Agente Comunitário b. Agente de Projetos Sociais c. Coletor } \\
\text { de Dados de Pesquisas e Informações Locais d. Auxiliar } \\
\text { Administrativo }\end{array}$ \\
\hline 10. Gráfica & $\begin{array}{l}\text { a. Guilhotineiro (Indústria Gráfica). b. Impressor Serigráfico c. } \\
\text { Operador de Acabamento (Indústria Gráfica). d. Encadernador }\end{array}$ \\
\hline 11. Joalheria & $\begin{array}{l}\text { a. Ourives na Fabricação e Reparação de Joias b. Fundidor c. } \\
\text { Auxiliar na Confecção de Bijuterias d. Vendedor de Comércio } \\
\text { (Joias, Bijuterias e Adereços). }\end{array}$ \\
\hline 12. Madeira e Móveis & $\begin{array}{l}\text { a. Marceneiro b. Reformador de Móveis c. Auxiliar de Desenhista } \\
\text { de Móveis d. Vendedor de Móveis }\end{array}$ \\
\hline 13. Metalmecânica & $\begin{array}{l}\text { a. Serralheiro b. Funileiro Industrial c. Auxiliar de Promoção de } \\
\text { Vendas d. Assistente de Vendas (Automóveis e Autopeças). }\end{array}$ \\
\hline $\begin{array}{l}\text { 14. Pesca e } \\
\text { Piscicultura }\end{array}$ & $\begin{array}{l}\text { a. Trabalhador na Pesca Artesanal b. Trabalhador na Piscicultura } \\
\text { c. Trabalhador em Unidades de Beneficiamento e Processamento } \\
\text { de Pescados d. Vendedor de Pescados }\end{array}$ \\
\hline 15. Saúde & $\begin{array}{l}\text { a. Auxiliar de Administração em Hospitais e Clínicas b. } \\
\text { Recepcionista de Consultório Médico e Dentário c. Atendente de } \\
\text { Laboratório de Análises Clínicas d. Atendente de Farmácia - } \\
\text { Balconista }\end{array}$ \\
\hline $\begin{array}{l}\text { 16. Serviços } \\
\text { Domésticos I }\end{array}$ & $\begin{array}{l}\text { a. Faxineira b. Porteiro c. Cozinheira no Serviço Doméstico d. } \\
\text { Caseiro }\end{array}$ \\
\hline $\begin{array}{l}\text { 17. Serviços } \\
\text { Domésticos II }\end{array}$ & $\begin{array}{l}\text { a. Cuidador de Idosos b. Passador de Roupas c. Cuidador de } \\
\text { Crianças (Babá). d. Lavadeiro }\end{array}$ \\
\hline 18. Serviços Pessoais & a. Manicura e Pedicura b. Depilador c. Cabeleireiro d. Maquiador \\
\hline 19. Telemática & $\begin{array}{l}\text { a. Operador de Microcomputador b. Helpdesk c. Telemarketing } \\
\text { (Vendas). d. Assistente de Vendas (Informática e Celulares). }\end{array}$ \\
\hline 20. Transporte & $\begin{array}{l}\text { a. Cobrador de Transportes Coletivos b. Despachante de Tráfego } \\
\text { c. Assistente Administrativo d. Ajudante Geral em Transportes }\end{array}$ \\
\hline $\begin{array}{l}\text { 21. Turismo e } \\
\text { Hospitalidade }\end{array}$ & $\begin{array}{l}\text { a. Organizador de Eventos b. Cumim (Auxiliar de Garçom). c. } \\
\text { Recepcionista de Hotéis d. Monitor de Turismo Local }\end{array}$ \\
\hline 22. Vestuário & $\begin{array}{l}\text { a) Costureiro b) Montador de Artefatos de Couro c) Costureira de } \\
\text { Reparação de Roupas d) Vendedor de Comércio Varejista. }\end{array}$ \\
\hline
\end{tabular}

O quadro comparativo, a seguir, mostra as principais mudanças ocorridas no Projovem implementado em 2005 e o Projovem Urbano implementado a partir de 2012. 
Quadro 5: Comparação entre as edições do Projovem em 2005, 2008 e 2012

\begin{tabular}{|c|c|c|c|}
\hline & $\begin{array}{c}\text { Projovem original } \\
(2005)\end{array}$ & $\begin{array}{c}\text { Projovem Urbano } \\
\text { (2008) }\end{array}$ & $\begin{array}{c}\text { Projovem Urbano } \\
\text { (2012) }\end{array}$ \\
\hline Idade & 18 a 24 anos & 18 a 29 anos & 18 a 29 anos \\
\hline $\begin{array}{l}\text { Grau de } \\
\text { instrução }\end{array}$ & $\begin{array}{l}\text { O jovem ter concluído } \\
\text { o ensino fundamental }\end{array}$ & $\begin{array}{l}\text { O jovem ter tido acesso } \\
\text { apenas a alfabetização } \\
\text { ou séries iniciais }\end{array}$ & $\begin{array}{c}\text { O jovem ter tido } \\
\text { acesso apenas a } \\
\text { alfabetização ou séries } \\
\text { iniciais }\end{array}$ \\
\hline $\begin{array}{l}\text { Quanto ao } \\
\text { trabalho }\end{array}$ & $\begin{array}{l}\text { Não poderia estar } \\
\text { inserido no mercado } \\
\text { formal de trabalho }\end{array}$ & $\begin{array}{l}\text { Já pode estar inserido } \\
\text { no mercado formal de } \\
\text { trabalho }\end{array}$ & $\begin{array}{l}\text { Já pode estar inserido } \\
\text { no mercado formal de } \\
\text { trabalho }\end{array}$ \\
\hline $\begin{array}{c}\text { Meta de } \\
\text { atendimento }\end{array}$ & $\begin{array}{l}200.000 \text { jovens, em } \\
\text { diferentes entradas }\end{array}$ & $\begin{array}{c}4 \text { milhões de jovens } \\
\text { (todas as modalidades) }\end{array}$ & $\begin{array}{c}\text { Foram pactuadas } \\
104.805 \text { vagas }\end{array}$ \\
\hline Base territorial & As 27 capitais das UFs. & $\begin{array}{l}\text { As } 27 \text { capitais das UFs } \\
\text { e municípios com mais } \\
\text { de } 200.000 \text { habitantes }\end{array}$ & $\begin{array}{c}\text { Adesão dos municípios } \\
\text { com população de } \\
100.000 \text { habitantes ou } \\
\text { mais. }\end{array}$ \\
\hline $\begin{array}{l}\text { Duração do } \\
\text { curso }\end{array}$ & 12 meses & 18 meses & 18 meses \\
\hline $\begin{array}{l}\text { Qualificação } \\
\text { profissional }\end{array}$ & $\begin{array}{c}\text { Era ofertada por } \\
\text { profissionais } \\
\text { especializados } \\
\text { contratados pelas } \\
\text { Secretarias (Educação } \\
\text { ou Assistência Social) }\end{array}$ & $\begin{array}{c}\text { Ofertada } \\
\text { conjuntamente com a } \\
\text { FTG - Formação } \\
\text { Técnica Geral desde a } \\
\text { primeira UF - Unidade } \\
\text { Formativa }\end{array}$ & $\begin{array}{c}\text { Composta pela } \\
\text { Formação Técnica } \\
\text { Geral - FTG, pela } \\
\text { Formação Técnica } \\
\text { Específica - FTE e } \\
\text { pelo Projeto de } \\
\text { Orientação Profissional } \\
\text { - POP } \\
\text { - A FTE é ofertada por } \\
\text { meio dos Arcos } \\
\text { Ocupacionais e/ou } \\
\text { cursos FIC/Pronatec. }\end{array}$ \\
\hline $\begin{array}{l}\text { Esquema do } \\
\text { Projovem } \\
\text { Urbano }\end{array}$ & Estação Juventude & $\begin{array}{c}\text { Pólos - para cada } 2400 \\
\text { jovens }\end{array}$ & $\begin{array}{l}\text { Núcleos como unidade } \\
\text { pedagógica básica do } \\
\text { Curso - Cada Núcleo } \\
\text { é composto por até } \\
200 \text { alunos distribuídos } \\
\text { em } 5 \text { turmas. }\end{array}$ \\
\hline Ação Social & Ação Comunitária & Participação Cidadã & Participação Cidadã \\
\hline $\begin{array}{l}\text { Supervisão e } \\
\text { monitoramento }\end{array}$ & $\begin{array}{c}07 \text { Universidades } \\
\text { responsáveis pelo SMA }\end{array}$ & $\begin{array}{l}10 \text { Universidades } \\
\text { responsáveis pelo SMA }\end{array}$ & $\begin{array}{c}\text { Sistema de Matrícula, } \\
\text { Acompanhamento de } \\
\text { Frequência e } \\
\text { Certificação dos } \\
\text { Estudantes do } \\
\text { Projovem Urbano - } \\
\text { SIMEC - Módulo } \\
\text { Projovem Urbano } \\
\end{array}$ \\
\hline \multirow[t]{2}{*}{$\begin{array}{l}\text { Coordenação } \\
\text { Nacional }\end{array}$} & SNJ & SNJ & $\begin{array}{c}\text { MEC - Diretoria de } \\
\text { Políticas de Educação } \\
\text { para a Juventude da } \\
\text { SECADI }\end{array}$ \\
\hline & - & - & $\begin{array}{l}\text { Estudantes passam a } \\
\text { ser contabilizados no } \\
\text { Censo Escolar/INEP }\end{array}$ \\
\hline
\end{tabular}

Fonte: elaborado pelo mestrando.

Para ressaltar a importância social e econômica do Projovem Urbano, é importante entender o que é o Bônus Demográfico. 


\subsection{População Jovem e o Bônus Demográfico}

De acordo com o UNFPA (2014) um bônus demográfico é possível quando a população em idade ativa torna-se relativamente maior do que a população fora da idade ativa. O bônus será grande ou pequeno dependendo, porém, da forma como o país investe no capital humano de seus jovens, da medida em que as políticas econômicas e outras políticas promovem o crescimento de empregos e oportunidades de geração de renda, e do grau em que as poupanças - das famílias e dos países - são investidas produtivamente na economia real.

Schmidt et al (2010) mencionam que boa parte dos jovens que compõem o bônus demográfico vem de situação de exclusão, tendo como retrato o baixo nível de escolaridade , pouca ou nenhuma capacitação profissional e ainda dificuldade de inserção no mercado de trabalho, no Brasil as condições demográficas são favoráveis ao desenvolvimento econômico, contudo para que esse bônus não se transforme em um ônus são necessárias políticas que tenham como objetivo interromper o ciclo vicioso de desigualdades sociais.

Segundo o UNFPA (2010) o Brasil é o $5^{\circ}$ país do mundo com maior percentual de "juventude" na sua população, atrás de China, Índia, EUA e Indonésia. Mais de $85 \%$ dos jovens do mundo vivem hoje nos países em desenvolvimento, sendo que o Brasil é responsável por aproximadamente $36 \%$ da população jovem da América Latina e Caribe e $80 \%$ do Cone Sul (Argentina, Brasil, Chile, Paraguai e Uruguai).

Os relatórios do IBGE (2012) dizem que houve uma queda na proporção de jovens e idosos em relação ao total de indivíduos em idade ativa. Há hoje proporcionalmente mais gente na faixa etária em que existe maior probabilidade de exercer atividade econômica do que aqueles potencialmente dependentes deste mesmo grupo. O que se verificou no Brasil foi uma redução da taxa de dependência de 60,3\% para 54,6\% entre 2001 e 2011. (Veja, 2012).

Assim, o Brasil teve a preocupação de inserir os jovens no mercado, pensando em aproveitar o seu bônus demográfico e observando que a juventude é a fase transitória para a vida adulta. Schmidt et al (2010) citando Alves (s.d) menciona que, com as mudanças na estrutura etária da população brasileira decorrentes da redução nas taxas de natalidade e mortalidade, a chamada transição demográfica, tem-se hoje no país uma população em idade ativa maior do que a população dependente, ocasionando uma redução na razão de dependência. De acordo com autores da área, essa menor carga de dependência tem um efeito macroeconômico, pois significa maior capacidade de poupança, condição indispensável para a elevação dos investimentos necessários ao desenvolvimento econômico.

Schmidt et al (2010) explica que considerando os dados do Censo 2010, observase que a população economicamente ativa corresponde a $77,5 \%$ da população total brasileira.

Bastos (s.d) explica que o crescimento do produto de um país é alcançado através do aumento dos fatores de produção, capital e trabalho, e do avanço tecnológico. Por isso, o crescimento populacional promove crescimento econômico via aumento da força de trabalho, e por esta razão, o crescimento demográfico é também chamado de bônus populacional. 
Gráfico 1: Bônus Populacional no Brasil - 1980 a 2050

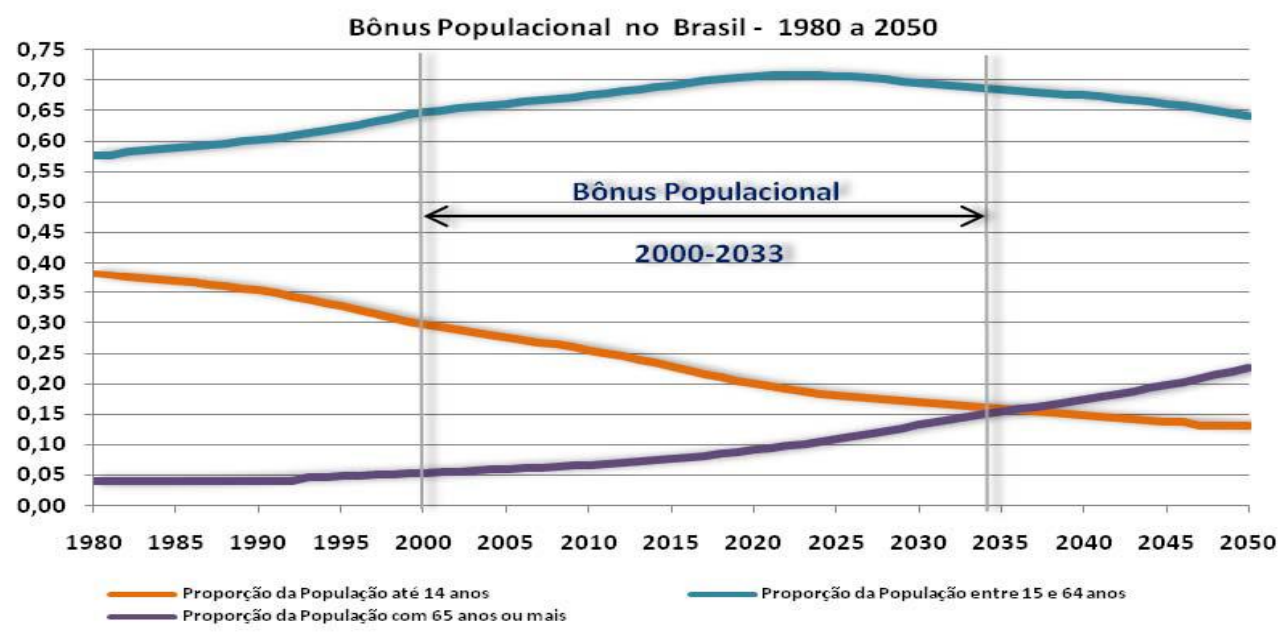

Fonte: IBGE apud Bastos (sd)

A autora explica que o Brasil tem que aproveitar o bônus populacional ate 0 ano de 2033 para obter um crescimento econômico de maneira sustentável, via política monetária, fiscal, investimento em educação e em infraestrutura para que o bônus populacional não seja desperdiçado. Após o fechamento dessa janela de oportunidade, o PIB brasileiro passará a crescer somente se o crescimento do capital e do desenvolvimento tecnológico for superior a taxa de crescimento populacional negativo. (BASTOS, s.d).

Neste sentido, Schmidt et al (2010) questionam sobre a capacidade do Brasil de reverter a favor de seu crescimento econômico a oportunidade vivenciada pela conjuntura demográfica. O país conta com uma trajetória de desigualdade social, o que se reflete em dados como os apresentados pelo DIEESE (2009) que, considerando a população acima de 10 anos, mostram na PEA um perfil de baixa escolaridade, no qual $8,2 \%$ da população economicamente ativa não possuem nenhum grau de instrução, $32,7 \%$ tem o ensino fundamental incompleto, $10,3 \%$ tem o ensino fundamental completo, 7,4\% tem o ensino médio incompleto, $26,5 \%$ ensino médio completo, $5 \%$ ensino superior incompleto e apenas $9,9 \%$ ensino superior completo. Assim, embora no presente o País passe por condições populacionais favoráveis, se o seu bônus demográfico não for bem aproveitado, poderá refletir em uma sobrecarga no futuro.

\subsubsection{População Jovem e Mercado de Trabalho}

De acordo com a Síntese de Indicadores Sociais do IBGE (2014) os jovens de 15 a 29 anos de idade correspondiam a $24,3 \%$ da população, em 2013 , e estavam presentes em $49,4 \%$ do total de arranjos familiares residentes em domicílios particulares, no Brasil. Nas famílias com ao menos um jovem de 15 a 29 anos de idade o rendimento mensal familiar per capita médio foi $36,3 \%$ inferior ao rendimento nos arranjos familiares sem jovens e $22,4 \%$ inferior ao rendimento familiar per capita médio do total dos arranjos familiares. 
Blanco (2010, p. 02) explica que os jovens no Brasil são uma das maiores vítimas da desigualdade:

(...) vivenciando mazelas no desemprego, violência, pobreza e na falta de projetos futuros. Mesmo sendo beneficiada transversalmente por políticas de educação, saúde, habitação e assistência social, a juventude continua sendo um hiato nas ações focais do governo, já que direitos específicos foram construídos ao longo da trajetória das políticas sociais no Brasil com foco principal para demandas dos trabalhadores, dos contribuintes (no caso da previdência) ou, ainda, para a infância.

Rocha (2008, p. 124) menciona sobre a falta de experiência dos jovens quando tentam ingressar no mercado de trabalho:

De fato são os jovens os mais diretamente afetados pelo contexto adverso do mercado de trabalho, uma vez que, normalmente, já estão em situação de desvantagem devido às suas características específicas, como a falta de experiência e a busca de experimentação. Ademais, como muitos dos jovens ainda não são chefes de família, a sua posição no âmbito familiar acaba por permitir ou estimular a instabilidade ocupacional, a qual, nessas condições, está associada a menores riscos.

Guimarães e Almeida (s.d) mencionam que a inserção produtiva dos jovens é um dos grandes desafios da política de emprego, pois trata-se de um público que enfrenta maiores dificuldades, principalmente por causa da baixa experiência. Assim, essa é uma faixa muito vulnerável à situação de desemprego e de desemprego em longo prazo.

Estudo feito pelo DIEESE (2006) diz que em razão das transformações pelas quais a economia vem passando, há dificuldades na inserção ocupacional da força de trabalho, sobretudo da população jovem. No contexto de um elevado excedente de mão-de-obra, os jovens em idade de trabalhar constituem um dos segmentos mais frágeis na disputa por um posto de trabalho e para quem o problema do desemprego é mais latente. Nesse sentido, mesmo quando o jovem consegue uma ocupação, verifica-se que esta apresenta características diferenciadas - normalmente é menos regular e mais precarizada. O problema da inserção ocupacional torna-se mais grave para jovens com determinados atributos pessoais, principalmente, para aqueles oriundos de famílias de menor renda.

Com relação ao direito à profissionalização, ao trabalho e à renda de jovens, previsto no Estatuto da Juventude (BRASIL, 2013b), em 2013, para os jovens de 15 a 29 anos de idade, a taxa de ocupação foi de 57,0\%, sendo que há grande heterogeneidade dentro deste grupo em relação à inserção em atividades produtivas e frequência à escola. Para aqueles com idade entre 15 e 17 anos de idade, a taxa de ocupação foi de 22,1\%, de acordo com dados da PNAD. Nesta faixa etária espera-se que o jovem esteja frequentando a escola, sendo este um direito garantido em lei. Assim, 67,8\% do total de pessoas neste grupo etário somente estudavam, $16,6 \%$ trabalhavam e estudavam e $5,5 \%$ somente trabalhavam. 


\subsubsection{Mercado de Trabalho para os Jovens no Distrito Federal.}

De acordo com estudo do DIEESE feito em 2005 e publicada em $2006{ }^{30}$, os jovens das grandes regiões metropolitanas e do Distrito Federal enfrentam enormes dificuldades para entrar no mercado de trabalho:

Quando ocupados, suas inserções variam em função da renda familiar, quanto à possibilidade de freqüentar escola, ao setor de atividade econômica em que trabalham, a forma de inserção, rendimentos, jornada de trabalho e região de domicílio. Assim, as diretrizes e os programas para a inclusão no mercado de trabalho e a formação profissional dos jovens não podem deixar de levar em consideração as desigualdades de oportunidades segundo a condição familiar deste segmento da população. (DIEESE, 2006, p. 02)

O DIEESE (2006) menciona que em 2005, no Distrito Federal e nas cinco regiões metropolitanas em que a Pesquisa de Emprego e Desemprego - PED foi realizada, a população jovem, entre 16 e 24 anos, somava 6,5 milhões de pessoas, correspondendo a $23,8 \%$ da população acima de 16 anos residente nestas áreas. Deste contingente - 4,6 milhões - fazia parte da força de trabalho local, na condição de ocupados ou de desempregados. Essas informações mostravam o quanto era expressiva a presença deste segmento na População Economicamente Ativa (PEA) com mais de 16 anos, representando um quarto dos trabalhadores $(25,0 \%)$.

Com relação aos ocupados com mais de 16 anos (15,2 milhões), os jovens representavam uma proporção de 20,7\%, totalizando 3,2 milhões de pessoas. No entanto, quando se consideraram os desempregados, a proporção era bem maior: entre os 3,2 milhões de desempregados acima de 16 anos nas regiões metropolitanas analisadas, 1,5 milhão de pessoas estavam na faixa etária entre 16 e 24 anos, o que significava $45,5 \%$ do total de desempregados acima de 16 anos. (DIEESE, 2006).

No Distrito Federal, segundo o DIEESE (2006) a estimativa da população acima de 16 anos e jovens de 16 a 24 anos era de: 1.642 .000 para a população total acima de 16 anos e entre 16 e 24 era de 431.000 .

A pesquisa do DIEESE (2006, p. 04) mencionava sobre a evolução recente da inserção dos jovens nos mercados de trabalho metropolitanos:

O grau de inserção dos jovens nos mercados de trabalho metropolitanos pode ser auferido por dois indicadores:

i) a pressão exercida por essa população em seus respectivos mercados de trabalho, expressa pela taxa de participação e;

ii) a falta de oportunidades, expressa pela taxa de desemprego.

\footnotetext{
${ }^{30}$ Dados da PED - Pesquisa de Emprego e Desemprego -, realizada pelo DIEESE, Fundação Sistema Estadual de Análise de Dados (Seade), Ministério do Trabalho e Emprego/FAT e governos locais, em cinco regiões metropolitanas (Belo Horizonte, Porto Alegre, Recife, Salvador e São Paulo) e no Distrito Federal.
} 
Conforme os dados da PED de 2005, verifica-se que a taxa de participação dos jovens foi bastante elevada e muito próxima da taxa das pessoas com 25 anos ou mais, embora os percentuais se diferenciassem nas regiões pesquisadas: as áreas do país que apresentam um mercado de trabalho mais dinâmico tendem a apresentar um engajamento mais expressivo dessa parcela da população. Assim em São Paulo, Belo Horizonte e Distrito Federal, a população jovem apresentou maior participação no mercado de trabalho, correspondendo a parcelas superiores àquelas registradas para o total da população com 25 anos e mais.

A pesquisa constatou também que:

A desagregação das taxas de participação dos jovens segundo grupos de idade mostrou ainda que a inatividade é maior entre aqueles que têm entre 16 e 17 anos, decorrente, em parte do maior tempo dedicado à educação e também da preocupação generalizada com incremento da formação profissional. A participação também é menor entre as jovens, acompanhando, em geral, o padrão de inserção da população acima de 16 anos. Observa-se, porém, que as distâncias entre a participação de homens e mulheres são menores do que aquelas observadas para a população com idade acima de 16 Tal fato pode sugerir uma mudança de comportamento das novas gerações em relação à presença feminina no mercado de trabalho. (DIEESE, 2006, p. 04).

No Distrito Federal, segundo o DIEESE (2006) as taxas de participação e de desemprego dos jovens de 16 a 24 anos e da população total acima de 25, ficou distribuída de acordo com o quadro a seguir:

Quadro 6: Taxas de participação e de desemprego dos jovens de 16 a 24 anos e da população total acima de 25 anos no DF

\begin{tabular}{|c|c|c|c|}
\hline \multicolumn{2}{|c|}{ Taxa de participação } & \multicolumn{2}{c|}{ Taxa de desemprego } \\
\hline $\begin{array}{c}\text { Jovens de } \\
16 \text { a } 24 \\
\text { anos }\end{array}$ & $\begin{array}{c}\text { População total acima } \\
\text { de } 25 \text { anos }\end{array}$ & $\begin{array}{c}\text { Jovens de } \\
16 \text { a } 24 \\
\text { anos }\end{array}$ & $\begin{array}{c}\text { População total acima } \\
\text { de } \\
25 \text { anos }\end{array}$ \\
\hline 72,4 & 72,6 & 35,4 & 12,4 \\
\hline
\end{tabular}

Fonte: DIEESE (2006)

O estudo do DIEESE (2006) pesquisou sobre a ocupação juvenil nas regiões analisadas, e verificou que os jovens ocupados somam 3.157 mil pessoas e equivalem a $20,7 \%$ do total de ocupados de 16 anos e mais. No Distrito Federal a estimativa da população ocupada acima de 16 anos e jovens de 16 a 24 anos era de 972.000 e 202.000, respectivamente.

A pesquisa do DIEESE (2006) constatou que entre os jovens, também se reproduz a desigualdade de oportunidades no mercado de trabalho verificada entre as mulheres, com algumas agravantes regionais e por faixas etárias explicadas por fatores culturais, sociais e econômicos. Em 2005, a proporção de mulheres ocupadas de 16 a 24 anos em relação ao total foi inferior à dos homens jovens ocupados em todas as seis regiões onde a PED é realizada. No Distrito Federal, 52,3\% eram homens e 47,7\% mulheres.

A pesquisa também traz a relação escola e trabalho e o que se verificou foi que a 
maioria dos jovens ocupados não conseguiu conciliar a formação escolar e profissional, nas seis regiões metropolitanas. A proporção de jovens ocupados que somente trabalha foi maior que a proporção de jovens que estuda e trabalha em todas as regiões investigadas. No Distrito Federal 33,9\% dos jovens estudavam e trabalhavam e $66,1 \%$ só trabalhavam (DIEESE, 2006).

A pesquisa verificou que a maior proporção de jovens ocupados possui o ensino médio completo em todas as regiões.

Quadro 7: Distribuição dos jovens ocupados de 16 a 24 anos segundo escolaridade no DF.

\begin{tabular}{|l|l|l|l|l|l|l|}
\hline \multirow{2}{*}{ DF } & $\begin{array}{l}\text { EF } \\
\text { incompleto }\end{array}$ & $\begin{array}{l}\text { EF } \\
\text { completo }\end{array}$ & $\begin{array}{l}\text { EM } \\
\text { incompleto }\end{array}$ & $\begin{array}{l}\text { EM } \\
\text { completo }\end{array}$ & $\begin{array}{l}\text { ES } \\
\text { incompleto }\end{array}$ & $\begin{array}{l}\text { ES } \\
\text { completo }\end{array}$ \\
\cline { 2 - 7 } & $16,7 \%$ & $11 \%$ & $15,5 \%$ & $39,6 \%$ & $13,2 \%$ & $3,9 \%$ \\
\hline
\end{tabular}

Fonte: DIEESE (2006)

O setor Serviços foi o que mais empregou os jovens no Distrito Federal, com $61,9 \%$ dos jovens ocupados. (DIEESE, 2006).

Quadro 8: Distribuição dos jovens ocupados de 16 a 24 anos segundo setor de atividade no DF

\begin{tabular}{|l|l|l|l|l|l|}
\hline Indústria & Comércio & Serviço & $\begin{array}{l}\text { Emprego } \\
\text { Doméstico }\end{array}$ & Construção & Outros \\
\hline $4 \%$ & $23,5 \%$ & $61,9 \%$ & $7,1 \%$ & $1 \%$ & $1 \%$ \\
\hline
\end{tabular}

Fonte: DIEESE (2006)

A pesquisa revelou ainda que, a maioria dos jovens ocupados no mercado de trabalho era assalariada e que a maioria trabalhou para o setor privado com carteira assinada. No Distrito Federal $49 \%$ trabalhavam com carteira assinada no setor privado e $20,8 \%$ sem carteira assinada. A pesquisa destacou a participação dos jovens assalariados do setor público que era de $10,2 \%$. O Rendimento médio mensal no Distrito Federal era de $R \$ 573,00$, maior que nas outras regiões metropolitanas pesquisadas (DIEESE, 2006).

A pesquisa também verificou a jornada de trabalho. Segundo o DIEESE (2006) em 2005, a jornada de trabalho média semanal foi muito alta para o conjunto dos jovens ocupados, principalmente, ao se considerar a possibilidade de conciliar trabalho e estudo, no Distrito Federal a jornada média era de 41 horas. 


\section{CAPÍTULO 4: OBJETIVOS E ASPECTOS METODOLÓGICOS}

\subsection{Objetivos}

O objetivo geral desta dissertação é analisar de que forma o Projovem Urbano contribuiu para que os jovens egressos da edição de 2012 do programa se inserissem no mercado de trabalho

Os objetivos específicos foram:

I. Identificar quantos estudantes, de fato, conseguiram o certificado de conclusão de curso;

II. Identificar quais foram os arcos ocupacionais selecionados para serem ofertados aos estudantes do Projovem da edição 2012.

III. Verificar se a qualificação profissional recebida no Programa ajudou os jovens a serem inseridos no mercado de trabalho e se os mesmos estão aplicando os conhecimentos adquiridos em sua profissão;

IV. Verificar se caso os jovens não tenham conseguido ingressar no mercado de trabalho, quais foram os motivos.

Para alcançar os objetivos propostos na dissertação foi utilizada a metodologia qualitativa e quantitativa.

A metodologia qualitativa, segundo Worthenat (et al., 2004), é aquela que se realiza em ambiente natural para descrição substantiva da realidade pesquisada, utilizando múltiplos métodos de coletas de dados, sendo que o pesquisador é o principal instrumento.

Dalfovo (et al., 2008) explicam que pesquisa qualitativa é aquela que trabalha de forma predominante com dados qualitativos, ou seja, a informação coletada pelo pesquisador não é expressa em números, ou então os números e as conclusões neles baseadas representam um papel menor na análise.

Na pesquisa qualitativa a preocupação maior está nas interpretações do que na quantificação. Sendo assim, os resultados estão mais focados no processo social do que na quantidade ou resultado. Outrossim, para este trabalho, utilizou-se a abordagem indutiva para análise de dados.

Segundo Gil (2012, p. 10) o método indutivo:

Parte do particular e coloca a generalização como um produto posterior do trabalho de coleta de dados particulares. De acordo com o raciocínio indutivo, a generalização não deve ser buscada aprioristicamente, mas constatada a partir da observação de casos concretos suficientemente confirmadores dessa realidade. Constitui o método proposto pelos empiristas (Bacon, Hobbes, Locke, Hume), para os quais o conhecimento é fundamentado exclusivamente na 
experiência, sem levar em consideração princípios preestabelecidos.

Gil (2012) explica que esse método, parte-se da observação de fatos ou fenômenos onde se pretende conhecer as causas e após compará-los com a finalidade de se saber as relações que existem entre eles e por fim, procede-se à generalização, com base na relação verificada entre os fatos e fenômenos.

Além dos dados do Simec fez-se uso de entrevista (roteiro em anexo 1). Foram entrevistadas a Coordenadora de EJA/GDF Leda Ferreira, a Coordenadora Geral de Políticas Pedagógicas para a Juventude do MEC Maria das Graças Correia Almeida. A entrevista é uma das técnicas mais utilizada nas Ciências Sociais. Segundo Gil (2012, p. 109):

Pode-se definir entrevista como a técnica em que o investigador se apresenta frente ao investigado e lhe formula perguntas, com 0 objetivo de obtenção dos dados que interessam a investigação. A entrevista é, portanto, uma forma de interação social. Mais especificamente, é uma forma de diálogo assimétrico, em que uma das partes busca coletar dados e a outra se apresenta como fonte de informação.

Utilizou-se a técnica de estudo de caso, segundo Yin (2001) há três situações nas quais o estudo de caso é indicado, quais sejam: a) quando o caso em estudo é crítico para se testar uma hipótese ou teoria explicitada; b) ser extremo ou único; c) quando o caso é revelador, que ocorre quando o pesquisador tem acesso a um evento ou fenômeno até então inacessível à pesquisa científica.

A utilização do questionário é importante visto que auxilia o pesquisador a conhecer melhor as informações sobre os jovens participantes do Programa.

Utilizou-se também a metodologia quantitativa. Para Minayo (1994) apud Dalfovo (et al., 2008, p. 11) é possível fazer uso das duas metodologias concomitamente:

(...) as relações entre abordagens qualitativas e quantitativas demonstram que: a) as duas metodologias não são incompatíveis e podem ser integradas num mesmo projeto; b) que uma pesquisa quantitativa pode conduzir o investigador à escolha de um problema particular a ser analisado em toda sua complexidade, através de métodos e técnicas qualitativas e vice-versa; c) que a investigação qualitativa é a que melhor se coaduna ao reconhecimento de situações particulares, grupos específicos e universos simbólicos.

Richardson (1989) apud Dalfovo (et al., 2008) explica que: "este método caracteriza-se pelo emprego da quantificação, tanto nas modalidades de coleta de informações, quanto no tratamento dessas através de técnicas estatísticas, desde as mais simples até as mais complexas".

Os dados quantitativos foram fornecidos pela Coordenadora da Educação de Jovens e Adultos da Secretaria de Educação do GDF Leda Ferreira. Os dados foram extraídos do Sistema Integrado de Monitoramento Execução e Controle do Ministério da Educação Simec e se referem ao número de matriculados, desistentes e concluintes do Programa. Este sistema é um portal operacional e de gestão do MEC, que trata do orçamento e monitoramento das propostas on-line do governo federal na área da educação e é no Simec que os gestores 
conseguem verificar e acompanhar o andamento dos Planos de Ações Articuladas nos estados e municípios ${ }^{31}$.

Além dos dados extraídos do SIMEC, foram aplicados questionários aos jovens que concluíram o Programa, a fim de se conhecer os dados como entrada, permanência e conclusão, bem como aspectos sociológicos que afetaram a vida do estudante antes e depois do Projovem.

O questionário (anexo 1) foi pré testado com 3 aplicações e após validado, em seguida foi aplicado a 44 jovens oriundos do Programa. Esses jovens foram identificados por seus nomes e escolas onde participaram do programa. As informações foram compiladas e formou-se um banco de dados que foi analisado por meio da construção de gráficos. Para a análise do banco de dados construído teve-se como população alvos os jovens concluintes da edição de 2012 do Programa.

\subsection{Análise dos dados}

As informações que serão analisadas foram obtidas a partir de entrevista com a Coordenadora de Políticas Pedagógicas para Juventude da Diretoria da Juventude do Ministério da Educação - professora Maria das Graças Correia de Almeida; de entrevista realizada com Coordenadora do Projovem no Distrito Federal junto à Secretaria de Educação - professora Leda Ferreira Barros, dos dados disponíveis no SIMEC, e das entrevistas aplicadas a 44 estudantes concluintes do Programa da edição de 2012.

\subsubsection{Projovem Urbano}

A entrevista foi realizada com a Coordenadora de Políticas Pedagógicas para Juventude da Diretoria da Juventude do Ministério da Educação Maria das Graças Correia de Almeida, no dia 22 de maio de 2015.

A Coordenadora comentou um pouco sobre a transição da Secretaria Nacional de Juventude Nacional para o Ministério da Educação, frisando que há o histórico dessa transição no Manual de Orientações Gerais do Projovem Urbano. A coordenadora disse que não estava no MEC na época da transição, e o que sabe é o que consta no manual, ela destacou que o que se pretendia era ampliar o atendimento de jovens e adultos para elevação de sua escolaridade, e que o Programa estava com um projeto pedagógico aprovado pelo Conselho Nacional, e que o jovem seria certificado pela rede pública e dessa forma o Programa passou, então, a ser considerado uma ação dentro da modalidade de jovens e adultos. Ela comentou, ainda, que quando o programa foi para o MEC o estudante passou a integrar o sistema de ensino e passou a ter todas as prerrogativas do estudante da rede pública passando a compor o censo escolar.

${ }^{31}$ Disponível em :

http://portal.mec.gov.br/index.php?option=com_content\&view=article\&id=143:sime c\&catid=114:sistemas-do-mec\&ltemid $=187$. 
Sobre a adesão ao Programa, a coordenadora não soube informar quantos Estados e Municípios fizeram adesão quando o Programa estava sob a coordenação da SNJ, apenas informou que o programa era executado pelos estados e pelos municípios com mais de 200 mil habitantes. Quando o ProJovem foi para o MEC houve a ampliação da base territorial, além dos Estados também passaram a compor o Programa os municípios com mais de 100 mil habitantes, passando a atender uma parcela maior da população.

A Coordenadora comentou que o Programa passou a ter um número maior de municípios interessados pelo programa, tendo expansão das metas de matrículas a qual é de livre adesão. Ela disse, ainda, que não saberia informar quais eram as metas antes, mas que sabe que eram audaciosas e que quando o Programa foi para o MEC começou-se a traçar metas mais modestas que davam mais condições aos Estados e Municípios de se organizarem pela estrutura do Programa e pela exigência pedagógica.

Com relação aos recursos a Coordenadora comentou, que como a adesão é voluntária, o MEC divulga no diário oficial, e as secretarias municipais e estaduais fazem a adesão. O recurso é calculado com base no número de estudantes matriculados e que é tido como suficiente para que a formação do estudantes seja concluída.

Com relação às dificuldades do Programa, a Coordenadora fala da falta de interesse dos gestores locais:

Hoje, tem-se 268 municípios com mais de 100 mil habitantes, desses somente 100 aderiram ao programa. Muitos municípios desistem do programa porque alegam que é muito trabalhoso, muitos professores que quando conhecem o programa desistem porque da muito trabalho, porque não querem ser responsáveis por ser orientador de uma turma.

De acordo com a coordenadora, há também o preconceito de muitos diretores:

Que acham que os jovens vão dar trabalho e prejudicar o andamento da escola, porque a escola esta muito bem organizada e eles não querem "esses" jovens dentro da escola, esses jovens geralmente não são os que estão no centro da cidade, são os que estão nas periferias das cidades, e as escolas podem achar que os estudantes podem trazer problemas porque podem bagunçar a escola, podem quebrar algo, podem usar drogas, podem ser má influencia para os demais da escola.

Outra dificuldade mencionada pela coordenadora diz respeito às estruturas técnico-pedagógicas que estão relacionadas às três dimensões do programa: a formação básica, a qualificação profissional e a participação cidadã. Essas três dimensões se articulam nos eixos estruturantes, nos eixos temáticos. As dificuldades, estariam, então, relacionadas à compreensão de todo esse processo integrativo.

\subsubsection{Projovem Urbano do Distrito Federal}

A entrevista foi realizada com a Coordenadora do Projovem no Distrito Federal junto à Secretaria de Educação - professora Leda Ferreira Barros, no dia 12 de maio de 2015, 
que está há 06 anos no cargo de Coordenadora.

O que se verificou pela fala da Coordenadora Leda Ferreira é que o Programa teve muitas dificuldades desde sua implementação, quais foram: a) a violência, b) drogas, c) o fato de jovens preferirem o trabalho ao estudo, d) a não oferta da qualificação profissional aos estudantes, que só receberam certificado de conclusão de ensino fundamental, e) a negociação na contratação de professores, já que o governo do Distrito Federal queria contratar os professores da casa, f) a questão territorial, ou seja, no DF não tem municípios e sim regionais ${ }^{32}$ de ensino, tratando-se de uma peculiaridade do DF e; g) a mudança de gestão, mencionando que em 2005 o Programa estava sob a responsabilidade da Secretaria de Estado do Trabalho do Governo do Distrito Federal - GDF ${ }^{33}$, na SEDEST - Secretaria de Estado de Desenvolvimento Humano e Social.

Já para a Coordenadora de Políticas Pedagógicas da Diretoria para a Juventude do MEC, o DF tem encontrado alguns pormenores para realizar o programa, no entanto, não há nenhum estudo para explicar porque o DF teve dificuldades e outros Estados talvez não tenham tido a mesma dificuldade. Pressupõe-se que isto está muito relacionado com a organização do espaço geográfico, mas isso é apenas uma hipótese, ela, também, não considera justo atribuir a culpa aos jovens. Foi informado pela coordenadora que o DF fez a edição 2012 e não fez a de 2013, devido a algumas dificuldades de organização, e que em agosto de 2015 o DF irá iniciar a edição 2014.

O Gestor quando se inscreve para ofertar o Projovem Urbano em seu Estado ou Município tem uma meta de matrícula estipulada, no caso do DF verificou-se o não atingimento da meta. A Coordenadora Leda. Informou que no Projovem 2005 - "Projeto Experimental" - que era de responsabilidade da Secretaria de Trabalho, SEDEST - Presidência da República, a meta era de 21.000 jovens, e que foram inscritos 19.075 jovens, mas apenas 8.598 foram matriculados e que destes apenas 1.997 concluíram o curso.

Em 2012 a meta foi de 800 matrículas, mas foram feitas 462 e efetivadas 354 e apenas 111 estudantes concluíram o Programa, o que é de cerca de $14 \%$ da meta inicial. Escolas que receberam o Programa no DF foram: Itapoã, Núcleo 1509, Sede EC 01; Ceilândia, Núcleo 1674, Sede EC 66; e Estrutural, Núcleo 1677, Sede CEF 02.

\footnotetext{
${ }^{32}$ No Distrito Federal tem-se Coordenações Regionais de Ensino: Brazlândia; Ceilândia; Gama; Guará; Núcleo; Bandeirante; Paranoá; Planaltina; Plano Piloto; Recanto das Emas; Samambaia; Santa Maria; São Sebastião; Sobradinho; Taguatinga. O Projovem Urbano esteve presente apenas nas Regionais de Ceilândia e do Paranoá.

${ }^{33} \mathrm{Na}$ época foi constituído Comitê Gestor do Projovem através do DECRETO No 26.132, DE 24 DE AGOSTO DE 2005, publicado no DODF DE 25.08.2005. Disponível no site: http://www.tc.df.gov.br/SINJ/Arquivo.ashx?id_norma_consolidado=47381
} 
Grafico 2: Metas de matrículas e alunos concluintes, Distrito Federal, 2015

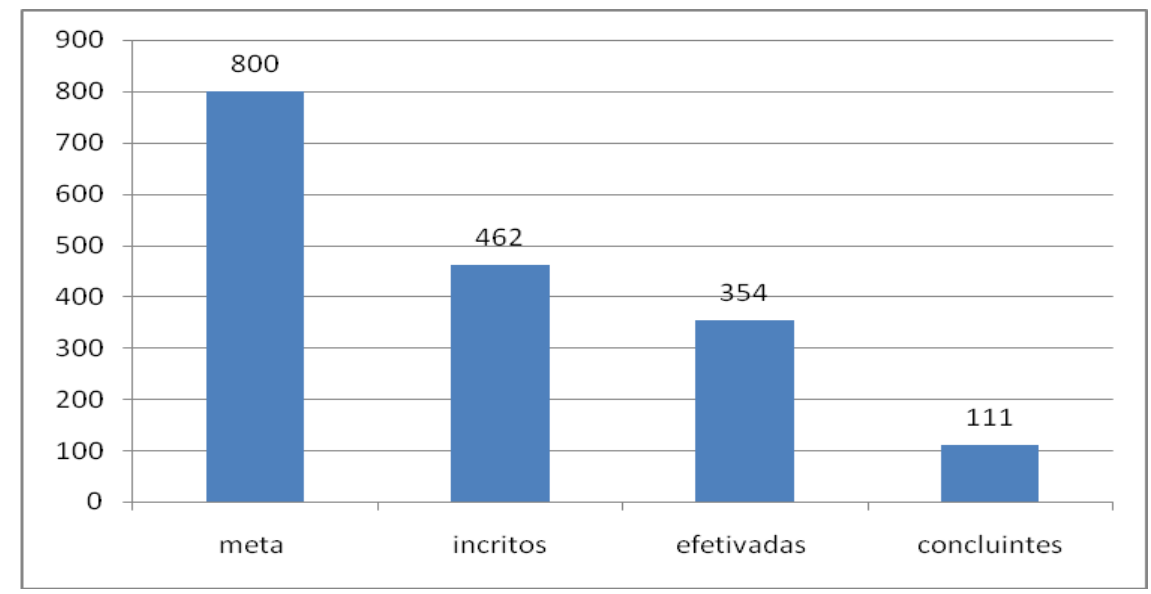

Fonte: Simec, gráfico elaborado pelo mestrando.

Para a Coordenadora do Programa no DF é difícil encontrar uma explicação por não se atingir a meta, contudo traz algumas hipóteses: a) condição sócio-econômica de Brasília; b) tem muitas escolas de EJA no DF; c) violência e drogas; d) o Programa não é atrativo para a faixa etária de 18 a 29 anos em Brasília; e) jovens que preferem o trabalho ao estudo; f) início das aulas, que estava previsto para junho, contudo as aulas só começaram em agosto, isso pode ter desmotivado muitos estudantes a retornarem para efetivar a matrícula.

Verificou-se que das 354 matrículas efetivadas 111 estudantes concluíram o Programa, ou seja, 31,63\%. Com relação à evasão desses estudantes a Coordenadora fez uma análise de cunho pessoal, as principais causas da evasão, para ela são o fator social e a faixa etária (18 aos 25), ela explicou que os jovens com mais idade já tem família e geralmente trabalham a noite. Outros fatores apontados pela Coordenadora são: a) violência; b) estudantes que foram presos e c) o marido que não deixa a esposa estudar à noite, ela mencionou, ainda, que muitas estudantes são mães e que a única escola com sala de acolhimento dos filhos dos estudantes era da Ceilândia.

Verificou-se também que no Distrito Federal existe a especificidade das Coordenações Regionais, ao todo são 15: Brazlândia; Ceilândia; Gama; Guará; Núcleo; Bandeirante; Paranoá; Planaltina; Plano Piloto; Recanto das Emas; Samambaia; Santa Maria; São Sebastião; Sobradinho; Taguatinga. Questionou-se o porquê de se escolher apenas duas: Ceilândia e Paranoá. Segundo a Coordenadora as escolas foram escolhidas pelo índice de vulnerabilidade dos jovens, ou seja, aquela região teve um índice bem elevado de violência. Além da questão da vulnerabilidade, foi consultado também a PNAD daquele período, pra saber se os jovens de 15 a 29 anos não tinham a escolaridade completa.

\subsection{Perfil dos estudantes do Projovem Urbano do Distrito Federal}

O perfil dos estudantes do Projovem no Distrito Federal foi traçado a partir das análises feitas, em um primeiro momento, com base no banco de dados disponibilizado pela Secretaria de Educação do GDF, o qual se apóia no SIMEC e tem os registros dos 111 estudantes, que concluíram o Programa na edição de 2012, dispondo de informações sobre 
nome, gênero, data de nascimento, etnia, estado civil, se tinham filhos, se eram beneficiários de outros programas, se tinham ocupação, se apresentaram histórico escolar, se fizeram teste de proficiência, se receberam o auxílio financeiro e o núcleo de ensino. A outra parte do perfil dos estudantes foi feita com base nas respostas dos próprios estudantes concluintes do Programa, nessa parte foram entrevistados 44 estudantes, as entrevistas foram tanto presenciais quanto por telefone, o roteiro de entrevistas foi colocado como anexo $n^{\circ} 1$.

Com as informações obtidas no banco de dados do SIMEC foi possível observar que das 354 matrículas efetivadas, 111 estudantes concluíram o Programa, ou seja, 31,63\% do total. Das matrículas foi constatado que 62 estudantes não realizaram o teste de proficiência, conforme mostra o gráfico a seguir.

Gráfico 3 - Teste de proficiência, Distrito Federal, 2012

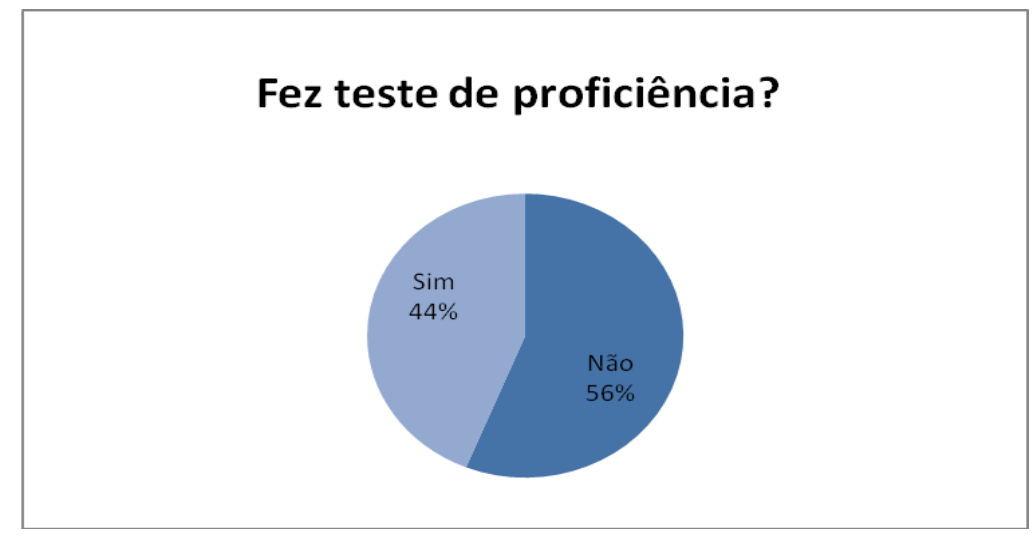

Fonte: Simec, gráfico elaborado pelo mestrando.

Observou-se que há, no programa a predominância de mulheres pardas, conforme mostra o gráfico abaixo com a distribuição feita por sexo e etnia.

Gráfico 4 - Distribuição por etnia e sexo, Distrito Federal, 2012

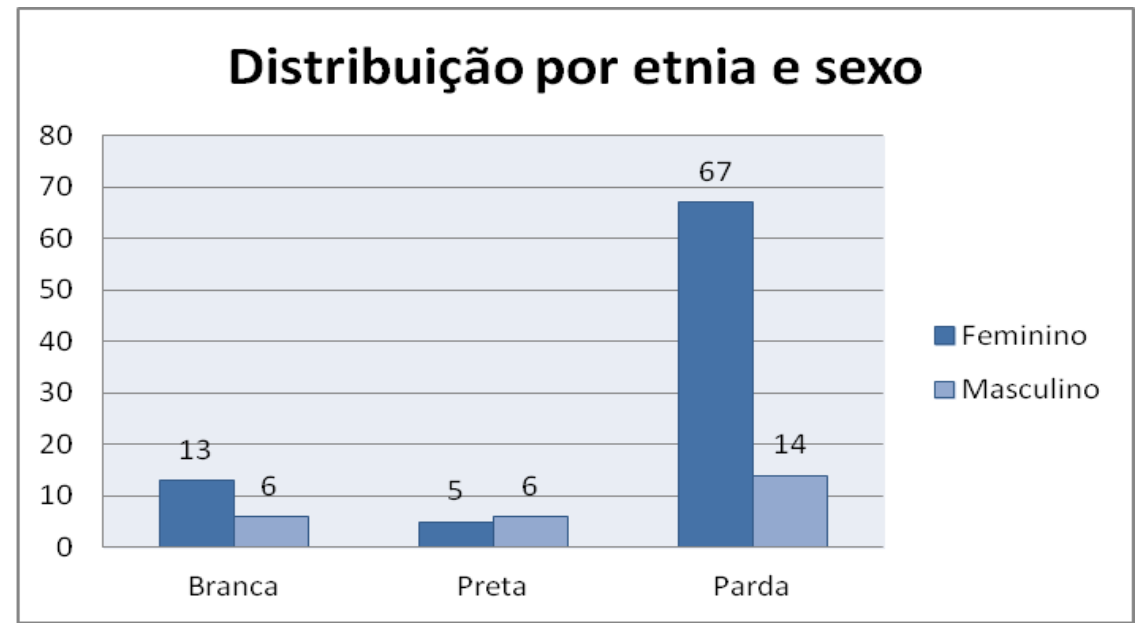

Fonte: Simec, gráfico elaborado pelo mestrando. 
O gráfico mostra que há, entre os concluintes, 85 mulheres para 26 homens, e que há a predominância da cor parda, cerca de $73 \%$ e que a menor distribuição por etnia está entre os que se declararam de cor preta sendo de cerca de $10 \%$ do total de estudantes.

Quanto à distribuição por idade o que se verificou é que o programa, de uma forma geral, teve um número maior de estudantes entre os jovens com mais idade do que os mais novos, com 62 estudantes com idades entre 26 a 30 anos.

Gráfico 5 - Distribuição por idade, Distrito Federal, 2012

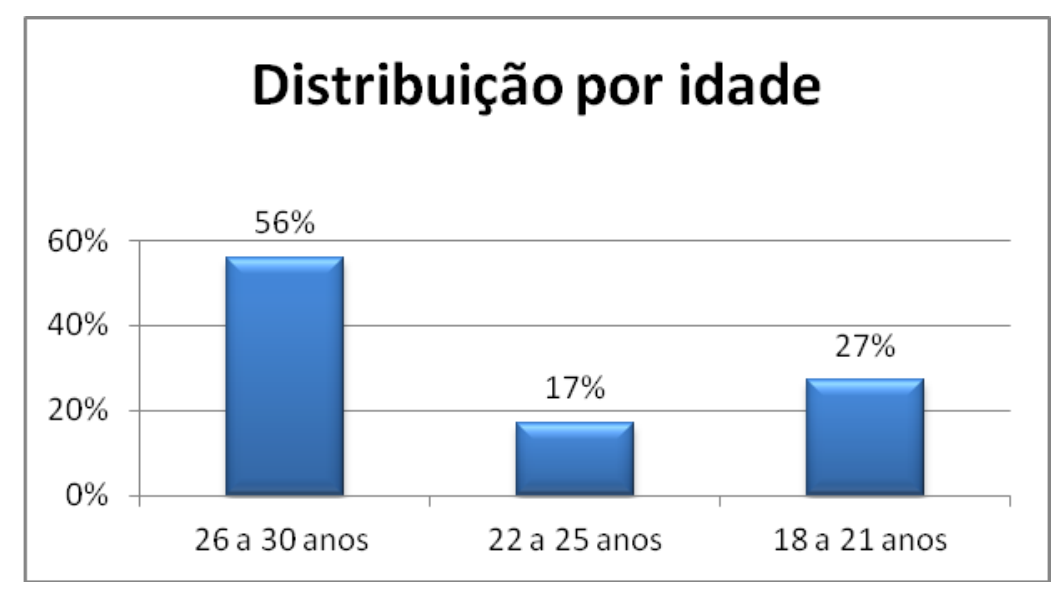

Fonte: Simec, gráfico elaborado pelo mestrando.

Os gráficos a seguir mostram a distribuição dos estudantes por estado civil e se possuíam filhos ou não, na época em que se matricularam no Programa. Há uma quantidade expressiva de estudantes, $48 \%$ que eram solteiros e que possuíam filhos, já entre os casados havia um total de $100 \%$ de estudantes com filhos.

Gráfico 6 - Estado Civil e Filhos, Distrito Federal, 2012

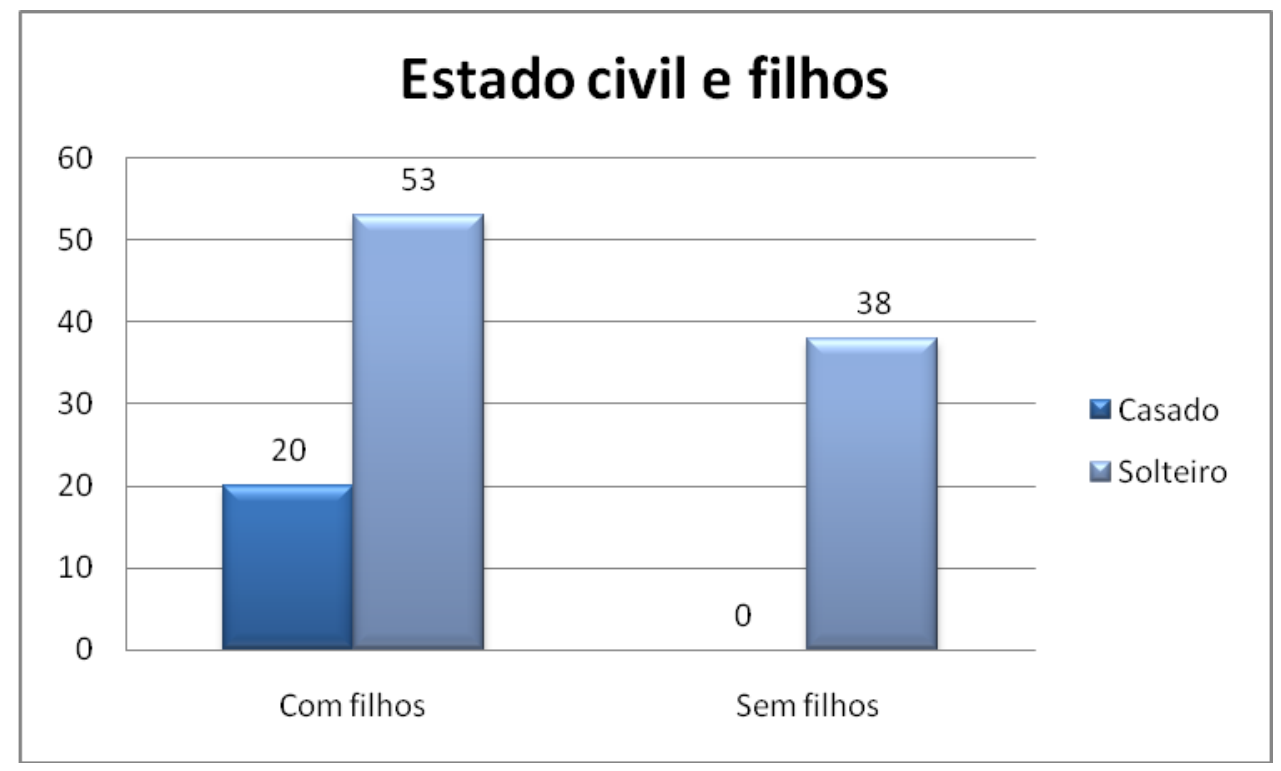

Fonte: Simec, gráfico elaborado pelo mestrando. 
Os estudantes com filhos representavam um total de cerca de $66 \%$ dos estudantes, e dentre esses estudantes verificou-se que a grande maioria deles era de mulheres, conforme mostra o gráfico abaixo, sendo um total de 44 mulheres solteiras e com filhos de um universo de 73 jovens.

Gráfico 7 - Solteiros com filhos, Distrito Federal, 2012

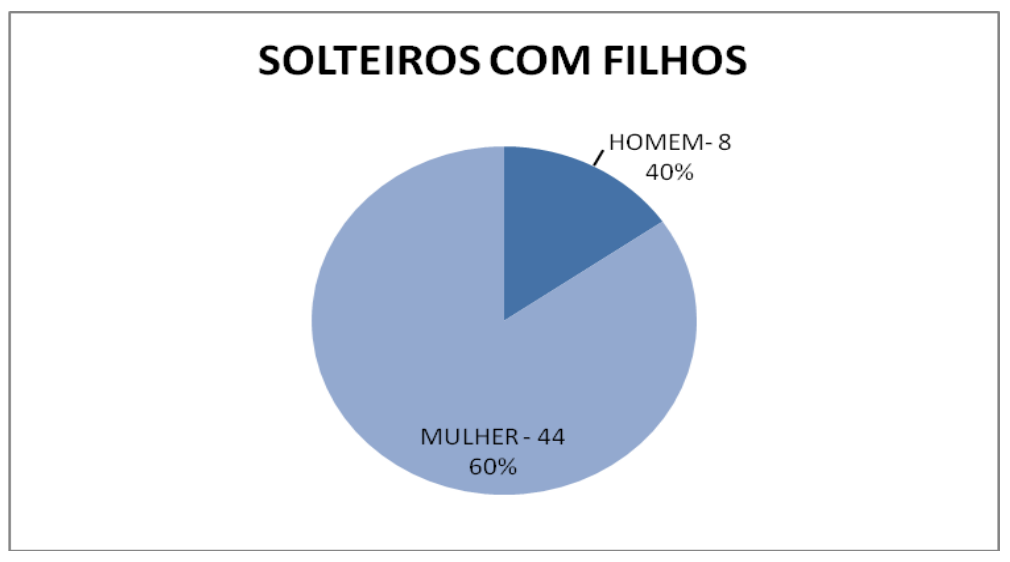

Fonte: Simec, gráfico elaborado pelo mestrando.

Do total de estudantes concluintes do Projovem todos eles receberam o auxílio financeiro em 18 parcelas, uma a cada mês, desse total apenas uma pessoa disse ter recebido auxílio financeiro de outro programa, e dos 111 estudantes beneficiários do Projovem apenas 26 disseram ter alguma ocupação.

Gráfico 8 - Possui alguma ocupação, Distrito Federal, 2012

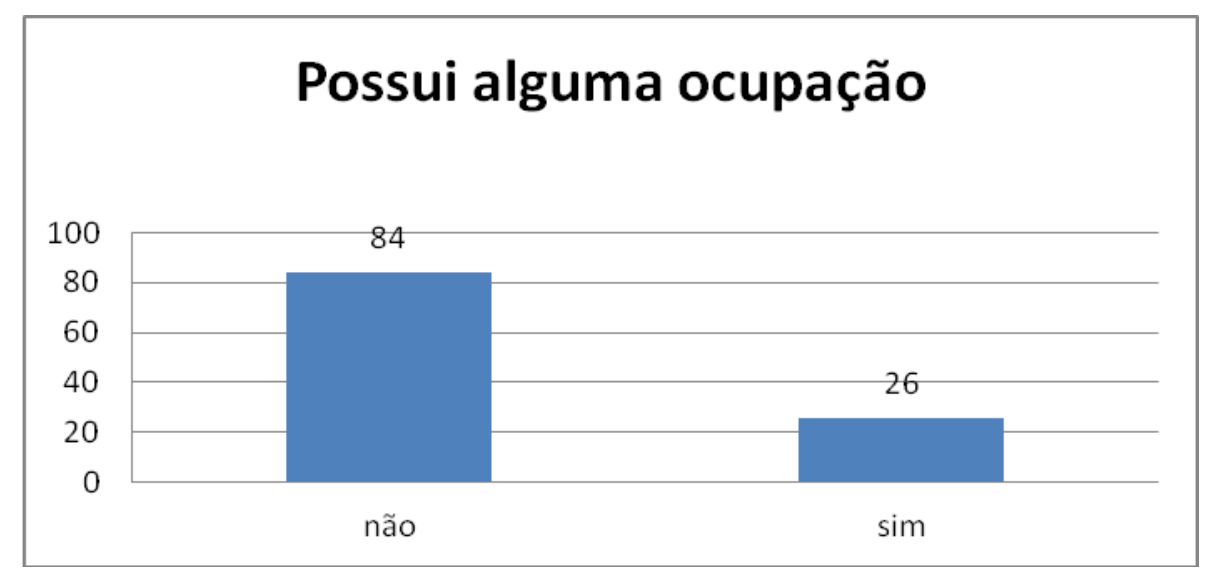

Fonte: Simec, gráfico elaborado pelo mestrando.

As análises e gráficos, a seguir, foram elaborados com base nas entrevistas aplicadas aos estudantes, assim pode-se continuar a verificar o perfil do jovem concluinte do Programa. Faz se necessário observar, aqui, que os questionários foram aplicados à população acessível à pesquisa, o que pode ter constituído um viés à própria pesquisa, haja vista que parte da população pode não ter sido encontrada por não estar em casa devido a fatores como estar em sala de aula ou mesmo trabalhando, assim a pesquisa feita, a partir de uma 
amostragem, pode carecer de um estudo mais aprofundado. As entrevistas que foram realizadas partiram dos endereços cadastrados no SIMEC, ou por meio dos telefones dos jovens cadastrados.

A primeira informação pesquisada foi de como os jovens ficaram sabendo do ProJovem, ao que foi respondido por $64 \%$ deles que havia sido por meio de propagandas, $25 \%$ por meio dos amigos, e 11\% por meio de divulgação feita dentro da própria escola. Dos 44 jovens entrevistados 31 disseram que se matricularam no Projovem na escola onde o Programa era divulgado, e ainda cerca de $23 \%$ dos jovens disseram que se interessaram pelo Programa porque era uma forma de concluir o ensino fundamental, conforme mostra o gráfico a seguir.

Gráfico 9 - Por que se interessou pelo Projovem, Distrito Federal, 2012

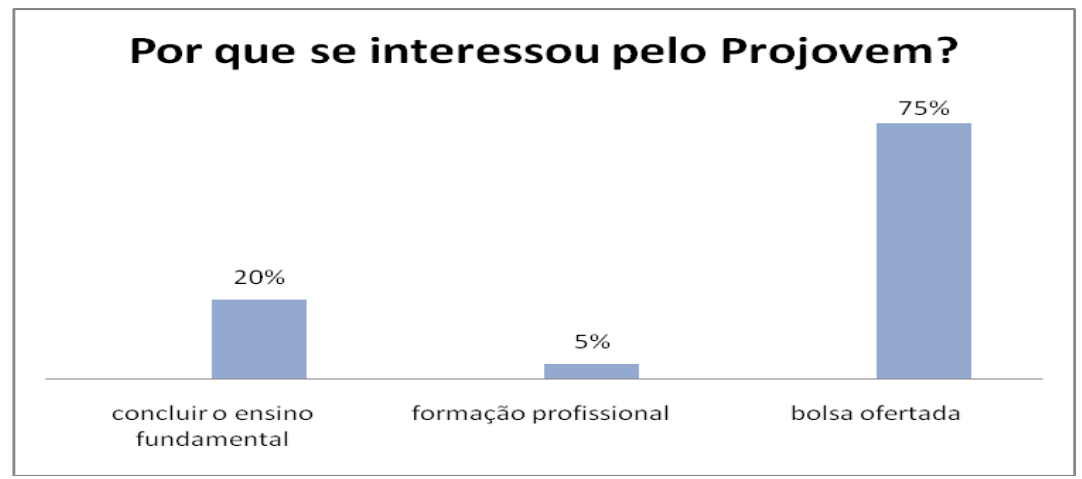

Fonte: Gráfico elaborado pelo mestrando, a partir de entrevistas com egressos do ProJovem Urbano do DF.

Foi perguntado aos jovens até que série eles haviam estudado antes de entrarem para o Programa e verificou-se que cerca de $96 \%$ dos alunos pararam na $5^{\underline{a}}$ ou $6^{\underline{a}}$ série de ensino.

Gráfico 10 - Até que série havia estudado antes do Projovem, Distrito Federal, 2012

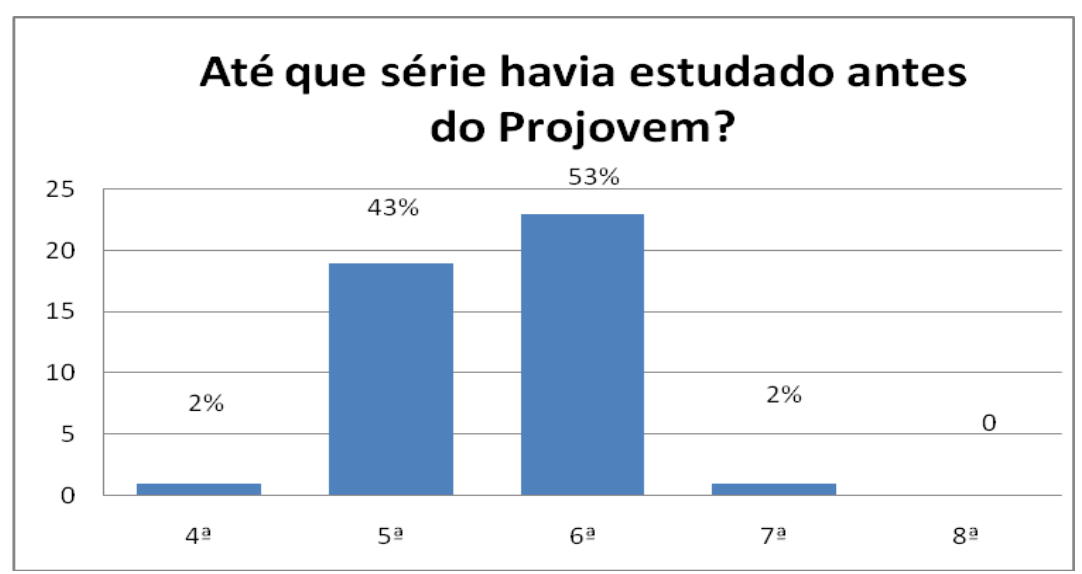

Fonte: Gráfico elaborado pelo mestrando, a partir de entrevistas com egressos do 
ProJovem Urbano do DF.

Os jovens foram indagados sobre suas expectativas com relação ao arco ocupacional antes e após o Programa, dos jovens entrevistados, 91\% deles disseram que acreditavam que poderiam melhorar sua renda com essa qualificação, conforme mostrado no gráfico abaixo.

Gráfico 11 - Expectativa sobre o arco ocupacional, Distrito Federal, 2012

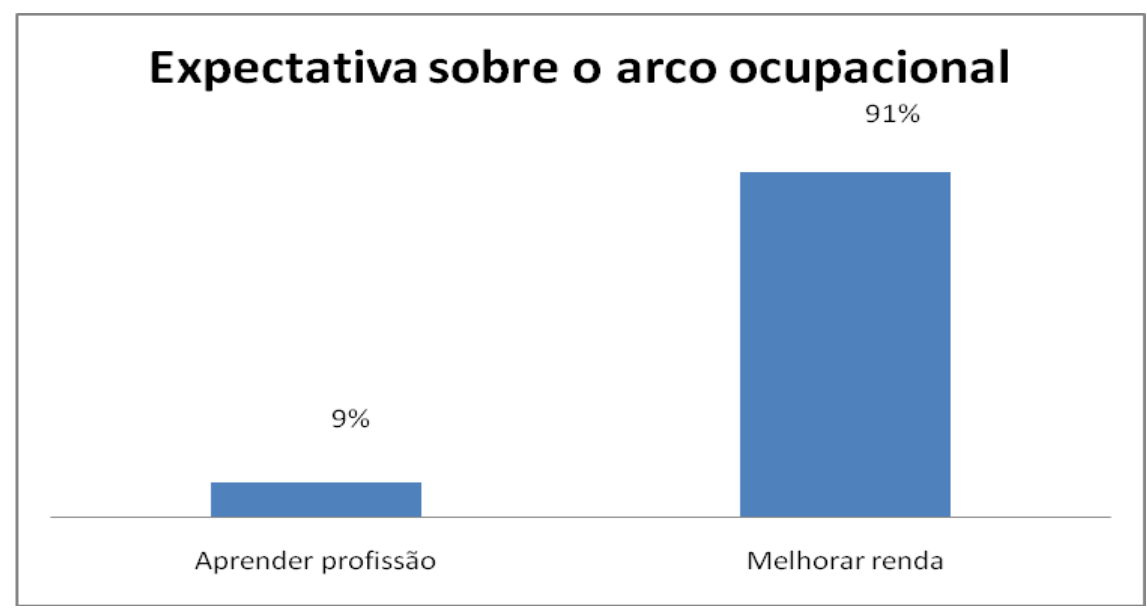

Fonte: Gráfico elaborado pelo mestrando, a partir de entrevistas com egressos do ProJovem Urbano do DF.

Em seguida foi perguntado aos jovens se o Programa ajudou de alguma forma a melhorar suas relações de trabalho, sendo que para somente $18 \%$ deles o arco ocupacional proporcionou alguma melhora na ocupação.

Gráfico 12 - Conseguiu emprego ou melhorou no emprego, Distrito Federal, 2012

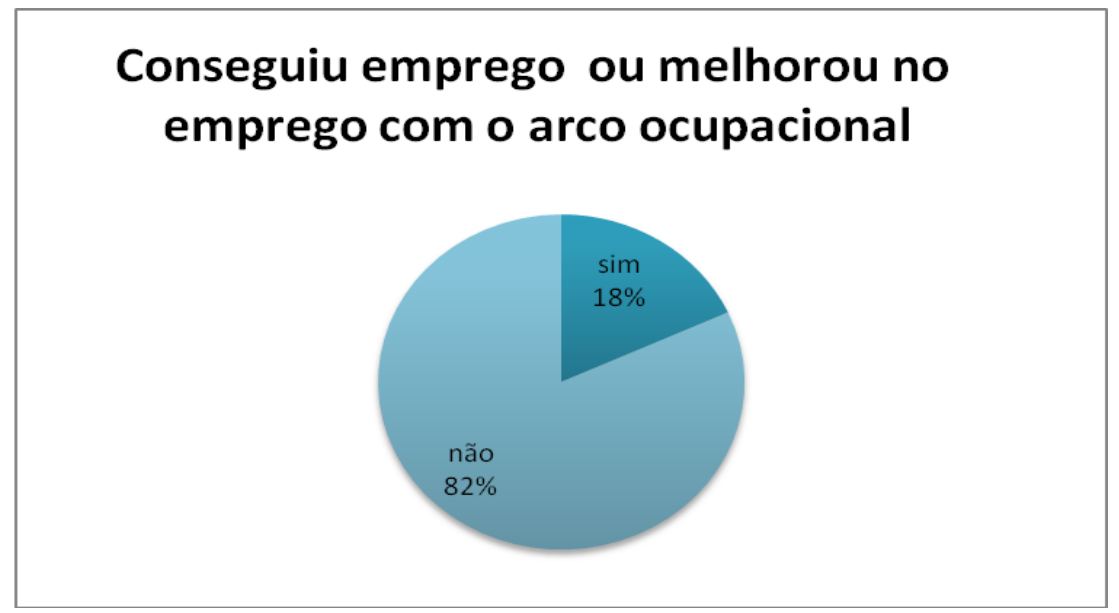

Fonte: Gráfico elaborado pelo mestrando, a partir de entrevistas com egressos do ProJovem Urbano do DF.

Os jovens entrevistados tiveram a oportunidade ainda de se manifestar sobre se 
suas opiniões iniciais sobre o Projovem Urbano foram confirmadas, sendo que cerca de $19 \%$, somente, disseram que os resultados obtidos por eles foram ao encontro do esperado.

Gráfico 13 - Opiniões sobre o ProJovem Urbano e arco ocupacional, Distrito Federal, 2012

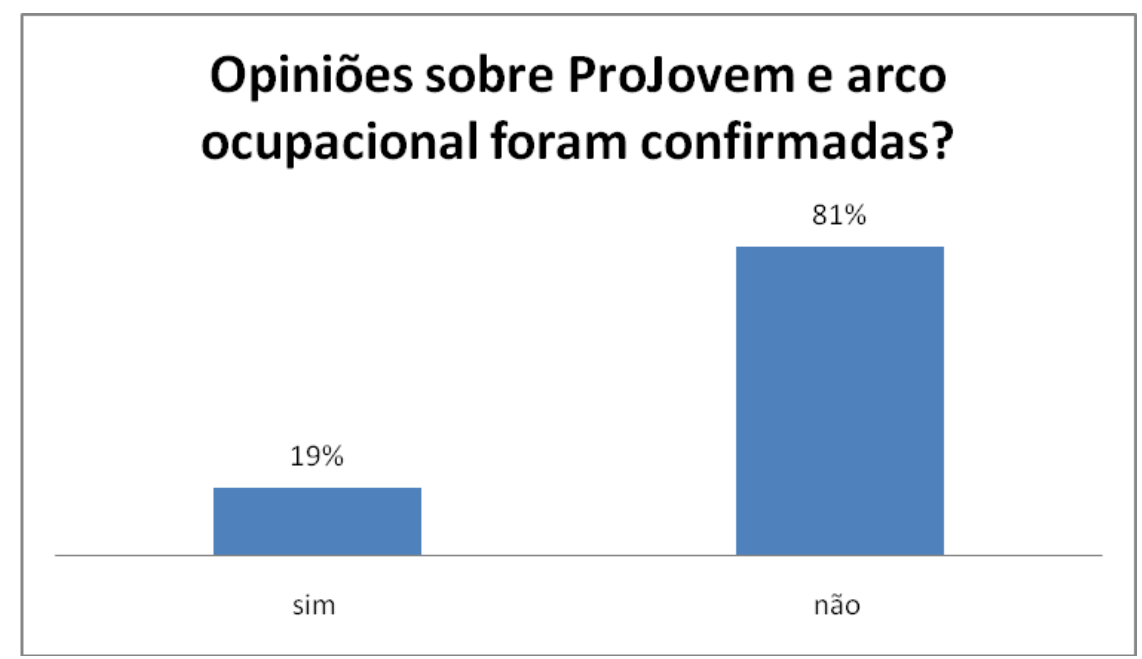

Fonte: Gráfico elaborado pelo mestrando, a partir de entrevistas com egressos do ProJovem Urbano do DF.

De acordo com as informações dadas pelos próprios estudantes verificou-se que cerca de $52 \%$ dos alunos abandonaram os estudos porque tiveram filhos e tiveram que trabalhar, e todos os alunos entrevistados disseram ter abandonado os estudos por apesar de terem tidos filhos ou casarem-se, terem de trabalhar.

Gráfico 14 - Por que largou os estudos, Distrito Federal, 2012

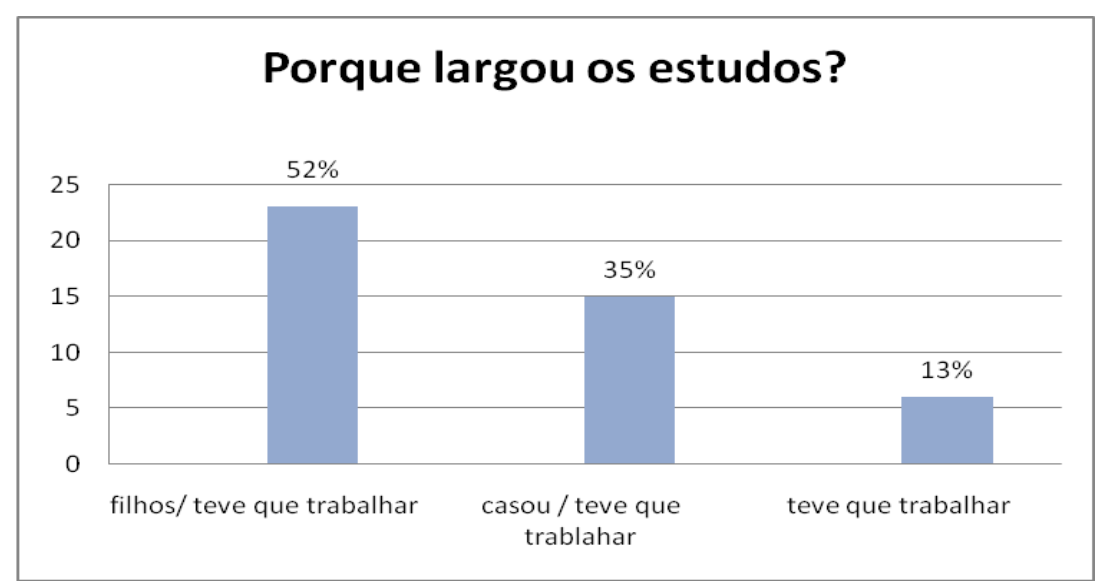

Fonte: Gráfico elaborado pelo mestrando, a partir de entrevistas com egressos do ProJovem Urbano do DF.

Pode-se observar ainda que a escolaridade da maioria das mães dos estudantes foi de até a $4^{a}$ série, e dos 44 estudantes entrevistados $31 \%$ disseram que o pai nunca havia estudado. 
Gráfico 15- Até que série seus pais estudaram, Distrito Federal, 2012

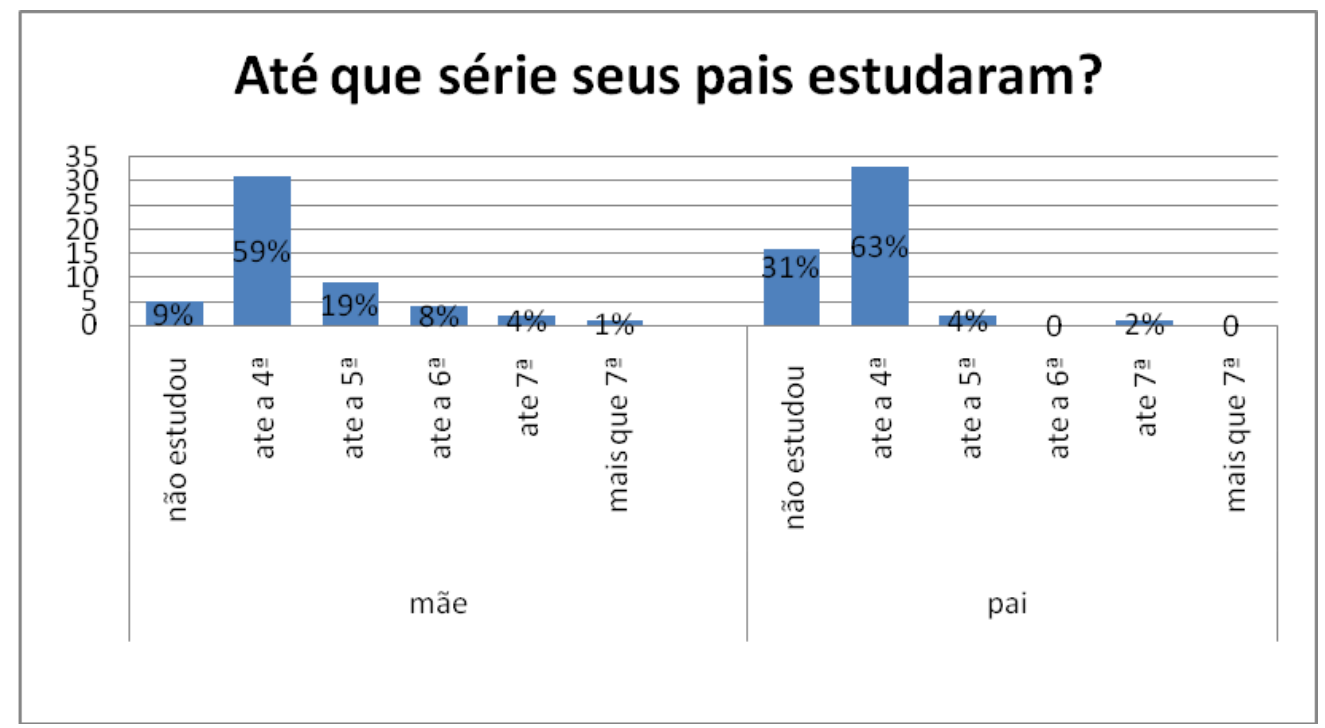

Fonte: Gráfico elaborado pelo mestrando, a partir de entrevistas com egressos do ProJovem Urbano do DF.

Quando perguntados se mais alguém da família já tinha estudado pelo Projovem Urbano, todos os 44 responderam negativamente. Foi perguntado, ainda, se os alunos modificaram sua visão sobre os estudos após o Programa ao que $75 \%$ dos entrevistados responderam que sim, a seguir foi perguntado se tinham ou não o desejo de continuar os estudos, e somente $23 \%$ disseram que não desejavam mais estudar, conforme mostra o gráfico abaixo.

Gráfico 16 - Quer continuar os estudos, Distrito Federal, 2012

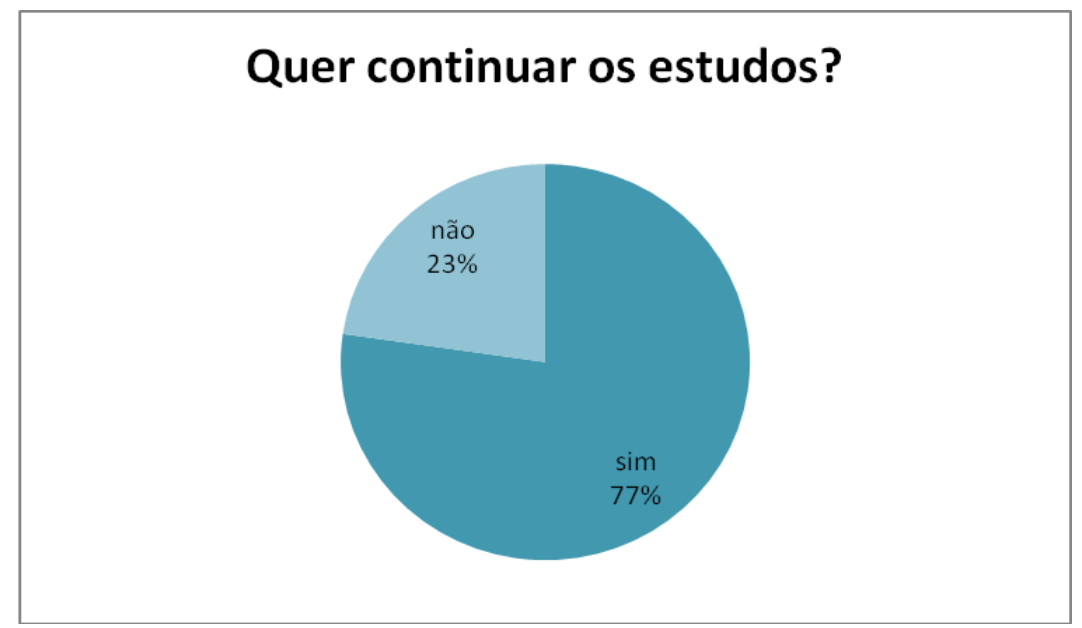

Fonte: Gráfico elaborado pelo mestrando, a partir de entrevistas com egressos do ProJovem Urbano do DF.

Com as informações coletadas, tanto pelos coordenadores do Programa em nível Distrital quanto em nível nacional, e com as informações obtidas através do Simec e com as entrevistas aplicadas aos alunos concluintes do Projovem pode -se analisar os dados apresentados nesse tópico, o que possibilitou chegar às considerações finais. 


\section{CONSIDERAÇÕES FINAIS}

A elaboração dessa dissertação propiciou conhecer o avanço das políticas públicas voltadas para a juventude, a partir disso verificou-se que as políticas para a juventude são recentes, visto que somente em 2005 é que o tema entrou para a agenda, com a implementação do Projovem . O Programa visa a atender jovens da faixa de 18 a 29 anos, que ainda não possuem o ensino fundamental completo. Além da elevação da escolaridade, o Programa integra ainda a qualificação profissional e a participação cidadã.

O objetivo proposto nesta dissertação foi analisar de que forma o Projovem Urbano contribuiu para que os jovens, egressos do Programa da edição 2012 do Distrito Federal, fossem inseridos no mercado de trabalho, para alcançar esse propósito foram feitas entrevistas com 44 dos estudantes concluintes, bem como entrevistas com a Coordenadora do Projovem Urbano no Distrito Federal, e a Coordenadora Geral de Políticas Pedagógicas para a Juventude do Mec.

No Distrito Federal o único Arco Ocupacional ofertado no curso foi o de alimentação, com as subáreas de chapista, repositor de alimentos e auxiliar de cozinha. A escolha pelo Arco Alimentação, de acordo com as informações da Coordenadora do Projovem no Distrito Federal, foi porque o governo do DF não contratou profissionais da área de educação para atuar no programa, optando por convocar os profissionais da casa, diante disso o arco alimentação pode aproveitar, também, os nutricionistas e merendeiras.

A partir dos dados coletados no SIMEC, foi possível observar que da meta inicial de 800 estudantes somente 111 conseguiram obter o certificado de conclusão do curso. Entre os possíveis motivos para o não atingimento da meta, poderia se apontar:

a) no período de matrículas as condições sócio econômica do Distrito Federal, a existência de muitas escolas de EJA, o programa não ser atrativo para os jovens de 18 a 29 anos, o fato de os jovens preferirem o estudo ao trabalho, e o atraso no início das aulas em 2012

b) no decurso do Programa poderíamos apontar fatores como a violência, a prisão de estudantes, os maridos que não queriam que suas esposas estudassem a noite, e embora haja a determinação de que se tenha salas de acolhimentos nas escolas o que se verificou foi que somente na Ceilândia tinha a sala.

Sobre a hipótese de os jovens preferirem o estudo ao trabalho, essa informação apenas reforça o que o DIEESE já havia pesquisado, em que a maioria dos jovens ocupados não conseguem conciliar a formação escolar e profissional. No distrito Federal apenas 33,9\% dos jovens entre 16 e 24 anos trabalhavam.

Com relação à hipótese da condição sócio econômica do DF a pesquisa do DIEESE de 2005 constatou que o rendimento médio mensal no Distrito Federal era de $\mathrm{R} \$ 573,00$, maior 
que nas outras regiões metropolitanas ${ }^{34}$ pesquisadas, o que pode ser um fator de extrema relevância para o não interesse dos jovens pelo Programa. Outrossim o estudo aponta que 10,2\% dos jovens são assalariados do setor Público, um índice maior que o encontrado nas outras regiões pesquisadas. Outro dado mencionado na pesquisa do DIEESE é que 39,6\% dos jovens do DF já possuem o ensino médio completo, com idades entre 16 e 24 anos o que indicaria que não há público para o Programa. Contudo, ao entrevistar os egressos, $75 \%$ dos respondentes disseram que se interessaram pelo curso em razão do pagamento da bolsa no valor de $R \$ 100,00$.

Embora houvesse uma expectativa, por parte dos jovens, de que o arco ocupacional pudesse melhorar sua renda, o que verificou-se, em resposta ao objetivo dessa dissertação foi que apenas $18 \%$ dos jovens teve alguma melhora na ocupação profissional, sendo pela melhoria nas condições de trabalho ou por aumento salarial, sendo que $19 \%$ dos jovens disseram que os resultados obtidos foram ao encontro do esperado. De acordo com os jovens entrevistados a qualificação obtida foi "muito básica, e que o tempo foi muito pouco", além disso os jovens explicaram que por questões de segurança e higiene os jovens não manuseavam os alimentos, apenas observavam, e que, durante o curso, realizaram somente uma visita aos supermercados para conhecer os alimentos. Cabe ressaltar que os arcos ocupacionais deveriam, em regra, ser desenvolvidos de acordo com as necessidades locais a fim de que os estudantes pudessem conhecer, aprender e posteriormente ingressar no mercado de trabalho, contudo no DF verificou-se que não foi feito um estudo sobre quais setores careciam de maior mão de obra, dessa forma os estudantes não tiveram a opção de escolher o arco ocupacional desejado.

Pode-se apontar, ainda, como uma dificuldade para o não atingimento das metas a não compreensão da estrutura técnico pedagógica do ProJovem Urbano, por parte dos profissionais de educação envolvidos no programa, que apresenta três dimensões, que são a formação básica a qualificação profissional e a participação cidadã, e que devem ser trabalhadas de forma articulada.

Além dos motivos elencados acima, acredita-se, ainda que o fato de $56 \%$ dos alunos não terem feito teste de proficiência possa ser apontado como um motivo para, num primeiro momento, o não atingimento do objetivos propostos pelo Programa, aliado a isso há a predominância de mulheres no programa que não teriam o apoio dos

maridos, ou mesmo de mães solteiras que não encontrariam as salas de acolhimentos nas escolas para deixarem seus filhos enquanto estudavam.

O Projovem Urbano é uma Política Pública relevante para os jovens, e ainda que tenha um caráter emergencial, o Programa precisa de uma melhor avaliação dos impactos ou resultados que vem apresentando no DF. O Programa tem objetivos ousados, quais sejam; integração social de jovens em condições precárias de escolaridade e renda e diminuição de desigualdades sócio econômicas, contudo desde sua implementação em 2005 tem sido alvo de

${ }^{34}$ Recife, Salvador, Belo Horizonte, Porto Alegre, São Paulo. 
críticas, entretanto essa transição do SNJ para o MEC pode fortalecer o programa visto que os estudantes passaram a ser contabilizados no censo escolar/INEP. E mesmo apesar de todas as dificuldades encontradas no Programa no DF tanto para a escolarização quanto para com o arco ocupacional, foi observado que o Projovem Urbano incutiu, de acordo com as respostas de $77 \%$ dos entrevistados, o desejo de continuar os estudos. 


\section{REFERÊNCIAS BIBLIOGRÁFICAS}

BALBACHEVSKY, J. O Programa Especial de Treinamento - PET/CAPES - e a graduação no ensino superior brasileiro .INFOCAPES. Boletim Informativo Vol. 6, № 2, abril/junho 1998.

BARRETTO, E. S. de S. Perspectivas teóricas e metodológicas da pesquisa em política educacional na atualidade. Texto baseado em exposição realizada em mesa redonda do mesmo título, que teve lugar no Seminário de Avaliação do PDE-Educação Básica e Intercâmbio de Pesquisa Científica. MEC/Anped: Brasília, 3 a 5 de setembro de 2008. Disponível em: http://www.fcc.org.br/pesquisa/publicacoes/eae/arquivos/1531/1531.pdf.

BARROS, M. O. F. A teoria da justiça de John Rawls. III Jornada Internacional de Políticas Públicas. São Luís - MA, 28 a 30 de agosto 2007.

BASÍLIO, A.L. Desvendado o PNE: a educação de jovens e adultos demanda lógica. Centro de Referências em Educação Integral. Publicado no dia 19/09/2014. Disponível no site: http://educacaointegral.org.br/noticias/desvendando-pne-educacao-de-jovens-adultos-e-mais-umcapitulo-da-divida-social-pais/

BASTOS, V. Bônus Populacional e Crescimento econômico. Disponível em: http://www.fgv.br/gvpreve/arquivo/estudos/Bonus\%20Populacional.pdf

BATISTA, Wilson Roberto. AS POLÍtICAS PÚBLICAS DE JUVENTUDE. Eixo Temático: Políticas Públicas e Gestão da Educação Agência Financiadora: não contou com financiamento. IX Congresso Nacional de Educação - EDUCERE. III Encontro Sul Brasileiro de Psicopedagogia. 26 a 29 de outubro de 2009. PUCPR. Disponível no site:http://www.pucpr.br/eventos/educere/educere2009/anais/pdf/3205_1506.pdf

BRASIL. Emenda Constitucional № 65, de 13 de julho de 2010. Altera a denominação do Capítulo VII do Título VIII da Constituição Federal e modifica o seu art. 227, para cuidar dos interesses da juventude. Disponível no site: http://www.planalto.gov.br/ccivil_03/constituicao/Emendas/Emc/emc65.htm.

Lei no 12.852, de 5 de agosto de 2013. Institui o Estatuto da Juventude e dispõe sobre os direitos dos jovens, os princípios e diretrizes das políticas públicas de juventude e o Sistema Nacional de Juventude - SINAJUVE. Disponível no site: http://www.planalto.gov.br/ccivil_03/_Ato2011-2014/2013/Lei/L12852.htm

Lei no 8.069, de 13 de julho DE 1990. Dispõe sobre o Estatuto da Criança e do Adolescente e dá outras providências. Disponível no site: http://www.planalto.gov.br/ccivil_03/leis/18069.htm

Ministério da Educação. Projovem Urbano. Disponível no site: http://portal.mec.gov.br/index.php?option=com_content\&view=article\&id=17462\&ltemid=817. Acesso em: out. 2012.

Presidência da República. ProJovem Programa Nacional de Inclusão de Jovens:Educação, Qualificação e Ação Comunitária. Presidência da República. SecretariaGeral da Presidência da República, março de 2005. 
Documento-Referência da Conae 2010. Ministério da Educação, Secretaria

Executiva Ajunta, Fórum Nacional de Educação. Disponível em: http://conae.mec.gov.br/images/stories/pdf/pdf/documetos/doc_base_conae_revisado2_sl.pdf

Documento Final da Conae 2014. Ministério da Educação, Secretaria Executiva

Ajunta, Fórum Nacional de Educação. Disponível em: http://conae2014.mec.gov.br/images/doc/Sistematizacao/DocumentoFinal29012015.pdf

.Lei no 13005 de 24 de junho de 2014. Aprova o Plano Nacional de Educação e da outras providências. Disponível em: http://www.planalto.gov.br/ccivil_03/_Ato20112014/2014/Lei/L13005.htm

CAMARANO, A. A.; MELLO, J. L.; KNASO, S. Juventude e envelhecimento na Conferência do Cairo: 15 anos depois no Brasil. In: ABEP/UNFPA, Brasil 15 anos após a Conferência do Cairo, Campinas, 2009.

CASTRO, H. C. de O. de; WALTER, M. I. M. T. SANTANA, C. M. B. de; STEPHANOU, M. C. Percepções sobre o Programa Bolsa Família na sociedade brasileira. Opin. Publica vol.15 no.2 Campinas Nov. 2009. Disponível: http://www.scielo.br/scielo.php?pid=S010462762009000200003\&script=sci_arttext

DALFOVO, M. S. LANA, R. A. SILVEIRA, A. Métodos quantitativos e qualitativos: um resgate teórico. Revista Interdisciplinar Científica Aplicada, Blumenau, v.2, n.4, p.01- 13, Sem II. 2008 ISSN 1980-7031. Disponível em:

http://www.unisc.br/portal/upload/com_arquivo/metodos_quantitativos_e_qualitativos_um_resga te_teorico.pdf

DIEESE. A ocupação dos jovens nos mercados de trabalho metropolitanos. Estudos e Pesquisas. Ano $3-\mathrm{n}^{\circ} 26$ - setembro 2006. http://www.DIEESE.org.br/estudosepesquisas/2006/2006pedjovensocupacao.pdf

BLANCO, D. M.. O Projovem Urbano Na Trajetória Das Políticas Para Juventude Desafios do programa e perspectivas de análise. Revista Brasileira de História \& Ciências Sociais Volume 2 - Número 3 - Julho de 2010. www.rbhcs.com. ISSN: 2175-3423

DUARTE, M. R.T. (org). Palavras de Jovens sobre o Projovem. Estudos com egressos e a formação de pesquisadores em avaliação de programas educacionais. Editora Escritório de História: Belo Horizonte, MG, 2009.

DYE, T. R. Understanding Public Policy. Englewood Cliffs, N. J.: Prentice Hall, 1995. 8a. ed. FAÇANHA, L. F. de C.; LIMA, S. O. O Ministério Público dos Estados e a implementação das Políticas Públicas Sociais: Um caminho para o enfrentamento à pobreza, à desigualdade e à exclusão social. IPEA, CODE 2011, Anais do I Circuito de debates acadêmicos. Disponível no site: http://www.ipea.gov.br/code2011/chamada2011/pdf/area2/area2-artigo25.pdf

GELINSKI, C. R. O. G; SEIBEL, E. J. Formulação de políticas públicas: questões metodológicas relevantes. Revista Ciências Humanas, Florianópolis, EDUFSC. V. 42 . N. 1 e 2, pág. 227-240. Abril e outubro de 2008. 
GIL, A. C. Métodos e Técnicas de Pesquisa Social. 6ª Ed. São Paulo: Atlas, 2012.

GUIMARÃES, A. Q.; ALMEIDA, M.E. Os jovens e o mercado de trabalho: evolução e desafios da política de emprego no Brasil. Disponível em:

http://webcache.googleusercontent.com/search?q=cache:ZET036E5ZkYJ:seer.fclar.unesp.br/te masadm/article/download/6845/4926+\&cd=2\&hl=pt-BR\&ct=clnk\&gl=br

HOWLETT AND RAMESH, Studying Public Policy: Policy Cycles and Policy Subsystems (Oxford, 2003)

INSTITUTO BRASILEIRO DE GEOGRAFIA E ESTATÍSTICA. Síntese de Indicadores Sociais do IBGE 2014.2 Disponível no site: ftp://ftp.ibge.gov.br/Indicadores_Sociais/Sintese_de_Indicadores_Sociais_2014/SIS_2014.pdf INSTITUTO DE PESQUISA ECONÔMICA APLICADA. Juventude e Políticas Sociais no Brasil. Jorge Abrahão de Castro e Luseni Aquino (org), IPEA: Brasília, 2009. Disponível no site: http://repositorio.ipea.gov.br/bitstream/11058/1485/1/TD_13

35.pdf

KANG, T. Justiça e desenvolvimento no pensamento de Amartya Sen. Rev. Econ. Polit. vol.31 no.3 São Paulo Sept. 2011. Disponível em: http://www.scielo.br/scielo.php ?pid=S0101-31572011000300002\&script=sci_arttext

LIMA, A. C. O; GONÇALVES, R.G. Projovem Urbano: contribuições da gestão social em sua avaliação. O público e o privado - № 21 - Janeiro/Junho - 2013. Disponível em: http://seer.uece.br/?journal=opublicoeoprivado\& page=article\&op=view

File\&path\%5B\%5D=574\&path\%5B\%5D $=753$

LUCENA, S. S.; SILVA, L. B. Análise do Programa Projovem Urbano no município de Pombal-PB. Trabalho de Conclusão de Curso Especialização em Gestão Pública Municipal. Modalidade à distância. Universidade Federal da Paraíba. Centro de Ciências Aplicadas. Departamento de Economia. Disponível no site: http://biblioteca.virtual.ufpb.br/files/analise_do_programa_projovem_urbano_no_municapio_de_ pombalpb_1343405025.pdf

LIMA, A. C. O; GONÇALVES, R.G. Projovem Urbano: contribuições da gestão social em sua avaliação. O público e o privado - № 21 - Janeiro/Junho - 2013. Disponível em: http://seer.uece.br/?journal=opublicoeoprivado\&page=article\&op=view File\&path\%5B\%5D=574\&path\%5B\%5D=753

LIRA, M. de F. L.; LEITE, J. A. C.; SILVA, A. A. C. G. T. da. Projovem Original e Urbano: Aspectos de uma ação voltada para juventude a partir de uma proposta de gestão integrada. http://www.cibs.cbciss.org/arquivos/ PROJOVEM\%20 ORIGINAL\%20E\%20URBANO.pdf

MANAIRDES, J. A abordagem do ciclo de políticas e suas contribuições para a análise da trajetória de políticas educacionais. Atos de pesquisa em educação - PPGE/ME FURB 
ISSN 1809- 0354 v. 1, no 2, p. 94-105, maio/ago. 2006. Disponível no site: http://ri.uepg.br:8080/riuepg/bitstream/handle/123456789/239/ARTIGO_

AbordagemCiclosPol\%C3\%ADticas.pdf?sequence=1

Mesquista, U. J.S. OS JOVENS E AS POLÍTICAS DE INCLUSÃO: análise do perfil social dos estudantes do Projovem. IV Jornada Internacional de Políticas Públicas. 25 a 28 de agosto de 2009. Universidade Federal do Maranhão. Programa de Pós-Gradruação em Políticas Públicas. Multicenter Sebrae. São Luis, Maranhão. Disponível no site: http://www.joinpp.ufma.br/jornadas/joinppIV/eixos/9_estados-e-lutas-sociais/os-jovens-eas-politicas-de-inclusao-analise-do-perfil-social-dos-estudantes-do-projovem.pdf

MÉSZÁROS, I. A educação para além do capital. Conferência de abertura do Fórum Mundial de Educação, realizado em Porto Alegre, no dia 28 julho de 2004.

NASCIMENTO, N. I. M. Programa Projovem Urbano: anotações sobre escolarização, inclusão social e juventude. Revista Enfoques PPGSA-IFCS-UFRJ Vol. 13 (1) Dezembro2013.

OMS/OPS. La salud del adolescente y el joven em las Américas, D.C., 1985.

REZENDE, M.; BAPTISTA, T. W. F. A Análise da Política proposta por Ball. In MATTOS, R. A.; BAPTISTA, T. W. F. Caminhos para análise das políticas de saúde, 2011. p.173-180. Online: disponível emwww.ims.ueri.br/pesquisa/ccaps.

RAWLS, John. Uma Teoria da Justiça. Brasília: Universidade de Brasília, 1981.

RUA, M. das G. A estrutura metodológica do monitoramento e da avaliação. Disponível no site: $\quad h$ ttp://translate.google.com.br/translate?hl=ptBR\&langpair=en\%7Cpt\&u=http://en.wikipedia.org/wiki/Community-based_monitoring \&ei=0DsVUeK1BoW-8ATWyoGQDQ

(b). Avaliação, instrumento estratégico no ciclo de gestão do PPA 2004-2007, "Avançar Mais". FÓRUM DA REDE GOIÁS. Disponível no site: www2.seplan.go.gov.br/redegoias/down/6_forum_avaliacao.ppt

(c). Análise de Políticas Públicas: Conceitos Básicos. Disponível no site: vsites.unb.br/ceam/webceam/nucleos/omni/.../pol_publicas.pdf

(d). Análise de Políticas Públicas: Conceitos Básicos. Disponível no site: vsites.unb.br/ceam/webceam/nucleos/omni/.../pol_publicas.pdf

(e). 0 Ciclo das Políticas Públicas. Aula 6. Instituto de Gestão Economia e Políticas Públicas - IGEPP. (s.d, c). Disponível em: http://igepp.com.br/uploads/videos/videoaula_6.1a_concepcao_de_ciclo_de_politicas._as_fases_do_ciclo_de_politicas_publicas.pdf

Políticas Públicas. Florianópolis: Departamento de Ciências da Administração/UFSC; (Brasília): CAPES:UAB, 2009.

SECCHI, L. Políticas Públicas. Conceitos, Esquema de Análise, Casos Práticos. São Paulo: Cengage Learning, 2012.

SECRETARIA NACIONAL DA JUVENTUDE. Programa Nacional de Inclusão de Jovens 
(Projovem). Disponível no site: http://www.juventude.gov.br/guia/principais-programas-dejuventude/programa-nacional-de-inclusao-de-jovens-projovem. Acesso em out. 2012.

Estatuto da Juventude. Portal da Juventude. Disponível no site: http://juventude.gov.br/estatuto\#.VNfpC_IdU9T

Sen, Amartya Kumar. Desenvolvimento como Liberdade/ Amartya Sen; Tradução: Laura Teixeira Motta; Revisão técnica: Ricardo Doniselli Mendes. São Paulo: Companhia das Letras, 2000

Sobre ética e economia/ Amartya Sen; Tradução: Laura Teixeira Motta; Revisão técnica: Ricardo Doniselli Mendes. São Paulo: Companhia das Letras, 1999.

SILVA JUNIOR, F. P. da. Teorias de justiça social e proteção social: Uma analise do papel do Estado na redução das desigualdades sociais. Trabalho publicado nos Anais do XIX Encontro Nacional do CONPEDI realizado em Fortaleza - CE nos dias 09, 10, 11 e 12 de Junho de 2010. Disponível no site:

http://www.conpedi.org.br/manaus/arquivos/anais/fortaleza/3646.pdf

SCHMIDT, B. V.; CASTRO, H. C. de O. de; CORRÊA, H. A. B.; FARIA, M. G. de. Programa Nacional de Inclusão de Jovens - ProJovem Estudo de Caso apresentado durante evento paralelo do Encontro de Alto Nível das Nações Unidas sobre Juventude, 25-26 de julho de 2011. Disponível em: http://www.unfpa.org.br/Arquivos/pro_jovem.pdf

ROCHA, S. A inserção dos jovens no mercado de trabalho. CADERNO CRH, Salvador, v. 21, n. 54, p. 533-550, Set./Dez. 2008.

SILVA, J. L. da. Conhecendo o Programa de Saúde do Adolescente. Universidade Federal Fluminense, junho, 2005. Disponível no site: http://www.uff.br/disicamep/prosad.htm

SOUZA, A. C. de; Gomes, P. Abordagem do Ciclo de Políticas segundo Stephen Ball. Disponível no site: http://www.puc-rio.br/pibic/relatorio_resumo2011/Relatorios/

CTCH/EDU/EDU-Ana\%20Carolina\% 20de\%20Souza\%20e\%20Paula\%20Gomes.pdf

TEIXEIRA, S. A. C. Boas Práticas Pedagógicas: Dilemas e transformações de educadores e educandos do Projovem Urbano. Orientadora: Prof ${ }^{a} \mathrm{Dr}^{\mathrm{a}}$ Maria Inês Corte Vitória Porto Alegre 2011. Pontifícia Universidade Católica do Rio Grande do Sul Faculdade de Educação Programa de Pós-Graduação em Educação Mestrado.

TARGINO, R. No Brasil, 3,4 milhões de jovens entre 18 e 24 anos não trabalham nem estudam. Disponível no site: http://educacao.uol.com.br/noticias/2011/04/06/no-brasil-34milhoes-de-jovens-entre-18-e-24-anos-nao-trabalham-nem-estudam.htm. Acesso em out. 2012. TODOS PELA EDUCAÇÃO. Anuário Brasileiro da Educação Básica 2015. Priscila Cruz e Luciano Monteiro (org). Moderna: São Paulo, 2015.

UNFPA - Fundo de População das Nações Unidas. Direitos da População Jovem. Um marco para o desenvolvimento. 2. ed. -- Brasília :UNFPA - Fundo de População das Nações Unidas, 2010. Vários colaboradores. 
. Fundo de População das Nações Unidas. Direitos da População Jovem. Um marco para o desenvolvimento. Situação da População Mundial 2014. http://www.unfpa.org.br/swop2014/link/cap5.pdf

VEJA. Estudo do IBGE mostra "bônus demográfico" do país. Nova Síntese de Indicadores Sociais do instituto evidencia a redução da chamada "taxa de dependência" de jovens e idosos. 28/11/2012 http://veja.abril.com.br/noticia/economia/estudo-do-ibgecomprova-bonus-demografico-do-pais\#quadro

WORTHEN at al. Avaliação de Programas: Concepções e práticas. Edusp. São Paulo, 2004.

YIN, R. K. Estudo de Caso: planejamento e métodos. 2ed. Porto Alegre: Brookman, 2001. 


\section{ANEXO 1: QUESTIONÁRIOS}

\section{Roteiro de entrevista - Estudantes}

1 - Sobre o Programa

a) Como ficou sabendo do programa Projovem Urbano?

- Propagandas

$\circ$ Amigos

- Na escola

- Outros /qual

b) Quais foram os motivos que te fizeram se interessar pelo programa?

- Era apenas uma forma de terminar o Ensino Fundamental

- Formação profissional

- Foi por pressão familiar

- Bolsa ofertada

- Outros /qual

c) Como se matriculou?

- Na escola

- Outros /qual

d) Em que escola teve as aulas?

- Ceilandia

○ Itapoa

- Estrutural

e) Que arco ocupacional foi escolhido por você?

f) Por que você escolheu esse arco ocupacional?

g) Quanto a expectativa com o arco ocupacional, qual era seu desejo inicial?

- Aprender uma profissão

- Melhorar a renda

- Outros /qual

h) Ao final do curso essas opiniões iniciais, tanto do curso quanto do arco ocupaconal foram confirmadas?

- Sim, de que forma? 
○ Não, por quê?

i) Em relação ao Projovem e o mercado de trabalho, você conseguiu um emprego ou melhorou seus conhecimentos sobre a função já exercida?

- Sim

○ Não

j) Você conseguiu um aumento ou promoção através do diploma ou da formação no Projovem Urbano?

○ Sim

○ Não

k) No que você acredita que o programa Projovem Urbano mais influenciou na sua vida?

I) Algum depoimento pessoal sobre coisas que marcaram durante e depois de frequentar o Projovem Urbano?

m) Tem a intenção de continuar os estudos?

- Sim. Ensino Médio ou técnico?

○ Não. Porquê?

2- Quando se formou no Projovem Urbano:

a) Até que série havia estudado?

b) Por que largou os estudos?

c) Mais alguém de sua família está no Projovem?

d) Até que série seu pai e sua mãe estudaram?

e) Que importância você atribui aos estudos em sua vida, antes de participar do programa Projovem Urbano?

3 - Sobre você

- Nome:

- Idade: $\quad$ Sexo: $\quad$ Estado Civil:

- Possui filhos: Quantos:

- Possui emprego:

- Trabalha com o que: Renda familiar: 
Roteiro de entrevista - Coordenador nacional(MEC)/Gestor do Projovem Urbano

- Nome do (a) entrevistado(a):

- Cargo:

- Quanto tempo no cargo:

1. Como são escolhidas as cidades participantes?

2. Quais são os pré-requisitos para os municípios poderem participar do programa?

3. Quantas escolas, no momento, estão participando do programa?

4. Como são feitas as escolhas dessas escolas?

5. Como é feita a escolha dos educadores que trabalham para o Projovem Urbano?

6. Quais são os arcos ocupacionais disponíveis nas escolas participantes?

7. Quantos jovens participaram do programa matrícula aberta em 2005 e em 2012?

8. Dos que entraram, quantos fizeram pelo menos uma avaliação, duas, ou as três avaliações?

9. Dos que fizeram as três avaliações todos se formaram?

10. Quantos se formaram e quantos evadiram e quantos abandonaram?

11. Sobre os estudantes evadidos? Sabem-se os principais motivos de sua evasão?

12. Quantos jovens receberam a bolsa de estudo?

13. Há dados da ultima serie cursada, antes de entrarem no programa?

14. Qual a distribuição por sexo?

15. Há dados sobre a etnia ?

16. Há dados de idades dos estudantes?

17. Como é o funcionamento das verbas disponíveis pelo governo? (Dar uma breve descrição do funcionamento do programa).

18. Como essa verba chega às instâncias responsáveis? 


\section{ANEXO 2: DIRETRIZES OPERACIONAIS - Parecer CNE/CEB no 11/200}

As Diretrizes Operacionais constantes no Parecer CNE/CEB no 11/200 - Diretrizes Curriculares Nacionais para a Educação de Jovens e Adultos, são:

Valorizar as experiências e os conhecimentos prévios dos jovens, tomando-os como base e ponto de partida para novas aprendizagens.

Reconhecer e valorizar as diferenças de gênero, de raça/etnia, cultura, religião etc.

Orientar as atividades de ensino de acordo com as potencialidades, as dificuldades específicas, bem como as formas e os ritmos de aprendizagem dos participantes. problemas.

Propiciar oportunidades de escolha e de tomada de decisão para resolução de

Planejar vivências de construção de regras e definição de responsabilidades.

Conjugar a unidade dos conteúdos de ensino propostos com a possibilidade de adaptação deles às peculiaridades regionais e/ou locais.

Enfatizar os conceitos básicos e as funções sociais das diferentes ciências, focalizando os respectivos conteúdos na perspectiva da vida contemporânea.

Adotar estratégias de ensino diversas (estudo de textos, vídeos e filmes, visitas programadas, pesquisa de campo, produção e revisão de textos escritos, exercícios práticos e orientados, roteiros para auto-correção etc.) que dialoguem com o mundo dos jovens, incentivando sua autonomia como aprendizes, despertando seu interesse por ampliar seus conhecimentos e suas experiências culturais.

Enfatizar o desenvolvimento de habilidades básicas, que facilitem a adaptação dos jovens às mudanças na realidade da organização do trabalho e da vida na sociedade.

Incluir espaços e tempos especialmente destinados a variadas formas de registro pessoal e à análise de suas próprias trajetórias familiares, comunitárias, escolares e profissionais, assim como à incorporação das novas informações e conhecimentos adquiridos.

Estimular a dimensão instituinte da prática, orientando o jovem a ler os textos e fazer as atividades de estudo pensando na prática e, da mesma forma, desenvolver essa prática refletindo sobre os conhecimentos que construiu ao estudar.

Incluir no percurso formativo situações pedagógicas que propiciem a aprendizagem de trabalho coletivo, de práticas associativas, de ações reivindicativas e propositivas que contribuam para a construção da participação cidadã dos jovens e que fomentem o exercício da democracia, da solidariedade, da cooperação.

Prever oportunidades para que os jovens tenham condição de participar ativamente da vida da comunidade em que moram.

Organizar o currículo em grandes áreas temáticas articuladas por eixos estruturantes, de modo que os conteúdos das disciplinas não se esgotem na carga horária atribuída a cada componente curricular e que, em cada período, se tenha um espaço garantido para concretizar estudos teórico-práticos e interdimensionais ligados à construção do conhecimento escolar, ao trabalho e à participação cidadã.

Tratar a avaliação como parte integrante e indispensável do processo de ensino e aprendizagem, que passa a ser considerado como "processo de ensino, aprendizagem e avaliação".

Centrar a avaliação no desempenho dos estudantes, de maneira contínua, progressiva e contextualizada, abrangendo todos os momentos e os diferentes aspectos do curso.

Avaliar múltiplos aspectos do desempenho dos jovens, indo além da aferição de conhecimentos e considerando atitudes, comportamentos, compromisso com o estudo e com a 
participação cidadã.

Utilizar diferentes procedimentos e instrumentos de avaliação, inclusive provas e trabalhos finais, para fundamentar a autoavaliação e a avaliação pelos colegas e pelos professores. 


\section{ANEXO 3 :MODALIDADES DO PROJOVEM}

\section{Projovem-Campo}

Além do Projovem Urbano há o Projovem Campo - Saberes da Terra que teve suas origens no Programa Saberes da Terra - Programa Nacional de Educação de Jovens e Adultos Integrada com Qualificação Social e Profissional para Agricultores/as Familiares.

No ano de 2007 o MEC através da SECAD participou do processo de construção do Programa Nacional da Juventude, que foi conduzido pela Secretaria Nacional de Juventude/Presidência da República (SNJ/SG/PR), no qual foram integrados seis programas já existentes: a) Agente Jovem, do Ministério do Desenvolvimento Social e Combate à Fome; b) ProJovem, da Casa Civil; c) Saberes da Terra e Escola de Fábrica, do Ministério da Educação; d) Consórcio Social da Juventude e Juventude Cidadã, do Ministério do Trabalho e Emprego. (PPP - ProJovem Campo Saberes da Terra, 2010).

Como já mencionado, em 2008, houve a integração do Programa Nacional de Inclusão de Jovens - ProJovem e neste processo de integração foi resguardada a autonomia político-pedagógica das experiências acumuladas por cada Programa.

A partir disso, o Saberes da Terra passou a denominar-se de ProJovem CampoSaberes da Terra destinado à garantia de ensino fundamental a jovens agricultores/as, como política de educação, na modalidade EJA integrada à qualificação social e profissional.

O ProJovem Campo - Saberes da Terra constitui-se no Programa Nacional de Educação de Jovens agricultores/as familiares, implementado pelo MEC através da SECAD e da Secretaria de Educação Profissional e Tecnológica (SETEC), numa ação integrada com os Ministérios do Desenvolvimento Agrário por meio da Secretaria da Agricultura Familiar (SAF) e da Secretaria de Desenvolvimento Territorial (SDT), do Trabalho e Emprego por meio da Secretaria de Políticas Públicas de Emprego (SPPE) e da Secretaria Nacional de Economia' Solidária (SENAES), o Ministério do Meio Ambiente por meio da Secretaria de Biodiversidade e Floresta (SBF), o Ministério do Desenvolvimento e Combate à Fome e a Secretaria Nacional de Juventude (SNJ) vinculada à Presidência da República. (PPP - ProJovem Campo Saberes da Terra, 2010).

Com a Resolução CD/FNDE № 21 de 26 de maio de 2008 estabeleceu-se os critérios e procedimentos para a transferência automática de recursos financeiros do Programa aos Estados no exercício de 2008.

O Programa atendeu jovens agricultores familiares com idade entre 18 e 29 anos, residentes no campo, que saibam ler e escrever e que não tenham concluído o ensino fundamental.

Tendo em vista que o Programa atende jovens agricultores, julga-se importante trazer o seu conceito. Considera-se agricultores, de acordo com a Resolução CD/FNDE № 21 de 26 de maio de 2008, os educandos que cumpram os requisitos do art. $3^{0}$ da Lei 11.326 , de 24 de julho de 2006: 
"Art. $3^{\circ}$ Para os efeitos desta Lei, considera-se agricultor familiar e empreendedor familiar rural aquele que pratica atividades no meio rural, atendendo, simultaneamente, aos seguintes requisitos:

I - não detenha, a qualquer título, área maior do que 4 (quatro) módulos fiscais;

II - utilize predominantemente mão-de-obra da própria família nas atividades econômicas do seu estabelecimento ou empreendimento;

III - tenha renda familiar predominantemente originada de atividades econômicas vinculadas ao próprio estabelecimento ou empreendimento;

IV - dirija seu estabelecimento ou empreendimento com sua família.

$\S 1^{\circ}$ O disposto no inciso I do caput deste artigo não se aplica quando se tratar de condomínio rural ou outras formas coletivas de propriedade, desde que a fração ideal por proprietário não ultrapasse 4 (quatro) módulos fiscais.

$\S 2^{\circ}$ São também beneficiários desta Lei:

I - silvicultores que atendam simultaneamente a todos os requisitos de que trata o caput deste artigo, cultivem florestas nativas ou exóticas e que promovam o manejo sustentável daqueles ambientes;

II - aqüicultores que atendam simultaneamente a todos os requisitos de que trata o caput deste artigo e explorem reservatórios hídricos com superfície total de até 2 ha (dois hectares) ou ocupem até $500 \mathrm{~m}^{3}$ (quinhentos metros cúbicos) de água, quando a exploração se efetivar em tanques-rede;

III - extrativistas que atendam simultaneamente aos requisitos previstos nos incisos II, III e IV do caput deste artigo e exerçam essa atividade artesanalmente no meio rural, excluídos os garimpeiros e faiscadores;

IV - pescadores que atendam simultaneamente aos requisitos previstos nos incisos I, II, III e IV do caput deste artigo e exerçam a atividade pesqueira artesanalmente.

O objetivo geral do Programa é desenvolver políticas públicas de Educação do Campo de Juventude que oportunizem a jovens agricultores (as) familiares excluídos do sistema formal de ensino a escolarização em Ensino Fundamental na modalidade de Educação de Jovens e Adultos, integrado à qualificação social e profissional. (PPP - ProJovem Campo Saberes da Terra, 2010).

Quanto aos objetivos específicos estão: a) Elevar a escolaridade e proporcionar a qualificação profissional inicial de agricultores(as) familiares; b) Estimular o desenvolvimento sustentável, com recorte agroecológico e enfoque territorial, como possibilidade de vida, trabalho e constituição de sujeitos cidadãos no campo; c) Fortalecer o desenvolvimento de propostas pedagógicas e metodologias adequadas à modalidade de EJA no campo; d) Realizar formação continuada em metodologias e princípios político-pedagógicos voltados às especificidades do campo para educadores(as) atuantes no Programa; e) Fornecer e publicar materiais pedagógicos que sejam apropriados ao desenvolvimento da proposta pedagógica; e f) Conceder auxílio financeiro aos educandos, minorando carências materiais que poderiam impedir sua freqüência ou manutenção no curso. (PPP - ProJovem Campo Saberes da Terra, 2010).

Um aspecto importante é a alteração da faixa etária, antes o Programa Saberes atendia jovens a partir 15 anos e adultos, com o redesenho do Programa o mesmo passa a limitar a idade de 18 a 29 anos. A faixa etária passa a ser componente de duas políticas de 
Estado - de Educação do Campo e de Juventude - ambas indispensáveis para a qualificação social, formação profissional e construção da autonomia dos jovens do campo.

Por um lado, se há o limitador quanto ao acesso aos maiores de 30 anos, por outro lado, no que tange ao Saberes da Terra, amplia as condições de implementação, tais como: a) aumento de $R \$ 1.000,00$ (um mil) reais para $R \$ 2.400,00$ (dois mil e quatrocentos) reais o investimento do Governo Federal por educando, repassado aos entes executores; b) garantia de recursos específicos para produção e distribuição dos cadernos pedagógicos; c) recursos específicos para realização da formação continuada, por meio de instituições de ensino superior públicas, na ordem de $\mathrm{R} \$ 5.700,00$ (cinco mil e setecentos) reais por cursista profissional em exercício no Programa e, d) instituição de auxílio financeiro de $R \$ 1.200,00$ (um mil e duzentos) reais por educando, pago em doze parcelas. (PPP - ProJovem Campo Saberes da Terra, 2010).

Quanto ao auxílio financeiro aos educando é importante mencionar sobre a Resolução CD/FNDE ํo 37 de 15 de Julho de 2009 que estabelece os critérios e procedimentos para o pagamento de auxílio financeiro aos educandos do Programa, a partir do exercício de 2009.

Outro aspecto que é importante mencionar é que o ProJovem Campo é desenvolvido pelos entes federativos estaduais ou municipais com prioridade aos Territórios da Cidadania ${ }^{35}$, em parceria com instituições de Ensino Superior públicas, organizações nãogovernamentais e movimentos sociais do campo. Embora os projetos e as transferências de recursos sejam exclusivamente a entes federativos - Estados e DF (podendo, também, ser Municípios) e instituições de Ensino Superior públicas (IES), é fundamental, para a garantia das características, da identidade e da estratégia político metodológica do Programa, que os projetos busquem e demonstrem a participação de outros sujeitos indispensáveis, tais como movimentos sociais e sindicais do campo, organizações populares de educação e assessoria com experiência em educação do campo, União Nacional de Dirigentes Municipais - UNDIME, EFA's, fóruns e comitês de educação do campo - incluindo a possibilidade de retribuição financeira por serviços eventuais, de pessoas físicas ou jurídicas destas parceiras, para atividades as quais estejam qualificadas a executar (seminários, oficinas, palestras, elaboração de material de apoio técnico-pedagógico, etc). (PPP - ProJovem Campo Saberes da Terra, 2010).

Com a edição 2008, foram disponibilizadas pela SECAD/MEC 35.000 (trinta e cinco mil) vagas, distribuídas em 19 estados da Federação: Alagoas, Bahia, Ceará, Maranhão, Pernambuco, Paraíba, Piauí, Rio Grande do Norte e Sergipe - região Nordeste; Mato Grosso e Mato Grosso do Sul - região Centro-Oeste; Santa Catarina e Paraná - região Sul; Minas Gerais

35 O Governo Federal lançou, em 2008, o Programa Territórios da Cidadania. O Territórios da Cidadania tem como objetivos promover o desenvolvimento econômico e universalizar programas básicos de cidadania por meio de uma estratégia de desenvolvimento territorial sustentável. A participação social e a integração de ações entre Governo Federal, estados e municípios são fundamentais para a construção dessa estratégia. Hoje são 120 Territórios da Cidadania. http://www.territoriosdacidadania.gov.br/dotlrn/clubs/territoriosrurais/one-community?page_num=0 
e Espírito Santo - região Sudeste; Amazonas, Pará, Rondônia e Tocantins - região Norte. $\mathrm{Na}$ Edição 200930.375 novas vagas foram ofertadas por Secretarias Estaduais de Educação.

Em 2010, a meta estabelecida era de 34.800 novas vagas. Contudo, a edição de 2010, não teve início. Os projetos foram apresentados por secretarias estaduais de educação e instituições públicas de ensino superior, de acordo com o Edital de Convocação № 4/2010 SECAD/MEC. E a meta do Programa é atender 275 mil jovens agricultores familiares até 2011. (PPP - ProJovem Campo Saberes da Terra, 2010).

\section{ProJovem Adolescente}

ProJovem Adolescente tem por foco o fortalecimento da convivência familiar e comunitária, o retorno dos adolescentes à escola e sua permanência no sistema de ensino. Isso é feito por meio do desenvolvimento de atividades que estimulem a convivência social, a participação cidadã e uma formação geral para o mundo do trabalho. O público-alvo constituise, em sua maioria, de jovens cujas famílias são beneficiárias do Bolsa Família, estendendo-se também aos jovens em situação de risco pessoal e social, encaminhados pelos serviços de Proteção Social Especial do Suas ou pelos órgãos do Sistema de Garantia dos Direitos da Criança e do Adolescente.

O ProJovem Adolescente ${ }^{36}$ é destinado aos jovens de 15 a 17 anos e oferece oportunidades socioeducativas para criar condições de inserção, reinserção e permanência do jovem no sistema educacional.

Podem se inscrever nesta modalidade os adolescentes de famílias beneficiárias do Programa Bolsa Família ou que estejam em situação de risco social, independentemente de renda (encaminhados pelo Conselho Tutelar ou Ministério Público, CREAS). Os portadores de deficiência têm preferência.

Nesta modalidade não há oferta de bolsas. As atividades socioeducativas são complementares à educação formal e é exigida a frequência regular à escola. Abordam conteúdos necessários para a compreensão da realidade e para a participação social, além de oferecer também o desenvolvimento de habilidades gerais, tais como a capacidade comunicativa e a inclusão digital. O Ministério do Desenvolvimento Social e Combate à Fome gerencia esta modalidade. 


\section{ProJovem Trabalhador}

O ProJovem Trabalhador ${ }^{37}$ tem como objetivo preparar o jovem para o mercado de trabalho e para ocupações alternativas geradoras de renda são os principais objetivos do ProJovem Trabalhador. Podem participar do programa os jovens desempregados com idades entre 18 e 29 anos, e que sejam membros de famílias com renda per capta de até meio salário mínimo.

O Projovem Trabalhador prepara os jovens para o mercado de trabalho e para ocupações alternativas geradoras de renda. Podem participar os jovens de 18 a 29 anos, que sejam membros de família com renda mensal per capita de até um salário mínimo, nos termos do regulamento. $O$ jovem tem de estar cursando ou ter finalizado o ensino fundamental ou médio.

De acordo com a assessoria técnica do Ministério do Trabalho e Emprego, responsável pela gestão desta modalidade, as vagas são abertas à medida que os estados e municípios firmam a parceria com o governo federal. Cabe aos estados e municípios a divulgação das vagas e dos períodos de inscrição.

Os cursos têm duração de 350 horas, divididas entre a qualificação social e qualificação profissional. Os jovens recebem uma bolsa auxílio de seis parcelas de $R \$ 100$, desde que obtenham a frequência mínima no período.

${ }^{36} \mathrm{http}: / / w w w . b r a s i l . g o v . b r / e d u c a c a o / 2012 / 04 /$ programa-capacita-jovens-para-o-mercado-detrabalho

${ }^{37} \mathrm{http}: / /$ www.brasil.gov.br/educacao/2012/04/programa-capacita-jovens-para-o-mercado-detrabalho 
Conversão da MPv no 411-07 - Dispõe sobre o Programa Nacional de Inclusão de Jovens - Projovem, instituído pela Lei no 11.129, de 30 de junho de 2005; altera a Lei no 10.836, de 9 de janeiro de 2004; revoga dispositivos das Leis nos 9.608, de 18 de fevereiro de 1998, 10.748, de 22 de outubro de 2003, 10.940, de 27 de agosto de 2004, 11.129, de 30 de junho de 2005, e 11.180, de 23 de setembro de 2005; e dá outras providências

O PRESIDENTE DA REPÚBLICA Faço saber que o Congresso Nacional decreta e eu sanciono a seguinte Lei:

Art. 10 O Programa Nacional de Inclusão de Jovens - Projovem, instituído pela Lei no 11.129, de 30 de junho de 2005, passa a reger-se, a partir de $\mathbf{1}^{\circ}$ de janeiro de 2008 , pelo disposto nesta Lei.

Art. 2ㅇ O Projovem, destinado a jovens de 15 (quinze) a 29 (vinte e nove) anos, com o objetivo de promover sua reintegração ao processo educacional, sua qualificação profissional e seu desenvolvimento humano, será desenvolvido por meio das seguintes modalidades:

I - Projovem Adolescente - Serviço Socioeducativo;

II - Projovem Urbano;

III - Projovem Campo - Saberes da Terra; e

IV - Projovem Trabalhador.

Art. 3o A execução e a gestão do Projovem dar-se-ão por meio da conjugação de esforços da Secretaria-Geral da Presidência da República e dos Ministérios da Educação, do Trabalho e Emprego e do Desenvolvimento Social e Combate à Fome, observada a intersetorialidade, sem prejuízo da participação de outros órgãos e entidades da administração pública federal.

$\S 1$ - Fica instituído o Conselho Gestor do Projovem, coordenado pela Secretaria Nacional de Juventude da Secretaria-Geral da Presidência da República e composto pelos SecretáriosExecutivos dos Ministérios referidos no caput deste artigo e por 1 (um) Secretário Nacional representante de cada um desses Ministérios, a ser indicado pelo respectivo Ministro de Estado.§ 20 O ProjovemAdolescente - Serviço Socioeducativo será coordenado pelo Ministério do Desenvolvimento Social e Combate à Fome; o ProjovemUrbano, pela Secretaria-Geral da Presidência da República; o Projovem Campo - Saberes da Terra, pelo Ministério da Educação; e oProjovem Trabalhador, pelo Ministério do Trabalho e Emprego.

§ 3 Cada modalidade do Projovem contará com 1 (um) comitê gestor, a ser instituído pelo órgão responsável por sua coordenação, assegurada nele a participação de representantes dos 3 (três) outros órgãos a que se refere o caput deste artigo.

Art. 4 Para a execução das modalidades tratadas no art. 2을 desta Lei, a União fica autorizada a transferir recursos aos Estados, ao Distrito Federal e aos Municípios, sem a necessidade de convênio, acordo, contrato, ajuste ou instrumento congênere, mediante depósito em contacorrente específica, sem prejuízo da devida prestação de contas da aplicação dos recursos.

$\S 1$ - O montante dos recursos financeiros a que se refere esta Lei será repassado em parcelas e calculado com base no número de jovens atendidos, conforme disposto em regulamentação, e destina-se à promoção de ações de elevação da escolaridade e qualificação profissional dos jovens, bem como à contratação, remuneração e formação de profissionais.

§ 2을 Os profissionais de que trata o § 1ㅇdeste artigo deverão ser contratados em âmbito local.

§ 3 Os órgãos responsáveis pela coordenação das modalidades do Projovem definirão, a cada exercício financeiro, a forma de cálculo, o número e o valor das parcelas a serem repassadas aos Estados, ao Distrito Federal e aos Municípios, bem como as orientações e instruções necessárias à sua execução, observado o montante de recursos disponíveis para este fim, constante da Lei Orçamentária Anual.

§ 4 Nas modalidades previstas nos incisos II e III do caput do art. 2을 desta Lei, a transferência 
de recursos financeiros será executada pelo Fundo Nacional de Desenvolvimento da Educação-FNDE, vinculado ao Ministério da Educação, observada a necessária descentralização dos recursos orçamentários pelos órgãos de que trata o caput do art. 3ํㅡㄹ desta Lei.

§ 50 A modalidade de que trata 0 inciso I do caput do art. 20 desta Lei será ofertada pelo Município que a ela aderir, nos termos do regulamento, e co-financiada pela União, Estados, Distrito Federal e Municípios por intermédio dos respectivos Fundos de Assistência Social, respeitado o limite orçamentário da União e os critérios de partilha estabelecidos pelo Conselho Nacional de Assistência Social, de acordo com o inciso IX do caput do art. 18 da Lei no 8.742, de 7 de dezembro de 1993.

$\S$ 6ㅇ Os saldos dos recursos financeiros recebidos pelos órgãos e entidades da administração pública federal, estadual, municipal e do Distrito Federal à conta do Projovem, existentes na conta-corrente específica a que se refere o caput deste artigo em 31 de dezembro de cada ano deverão ser aplicados no exercício subseqüente, com estrita observância ao objeto de sua transferência, nos termos da legislação vigente.

Art. 5o Os Estados, o Distrito Federal, os Municípios e as entidades de direito público e privado sem fins lucrativos prestarão conta dos recursos recebidos do Projovem, na forma e prazo definidos em regulamento e nas demais disposições aplicáveis.

Art. 6o Fica a União autorizada a conceder auxílio financeiro, no valor de $R \$ 100,00$ (cem reais) mensais, aos beneficiários doProjovem, nas modalidades previstas nos incisos II, III e IV do caput do art. 20 desta Lei, a partir do exercício de 2008.

$\S 1^{\circ}$ Na modalidade Projovem Urbano, poderão ser pagos até 20 (vinte) auxílios financeiros.

$\S$ 2 $\mathrm{Na}$ modalidade Projovem Campo - Saberes da Terra, poderão ser pagos até 12 (doze) auxílios financeiros.

$\S$ 3 $\mathrm{Na}$ modalidade Projovem Trabalhador, poderão ser pagos até 6 (seis) auxílios financeiros.

§ 4 É vedada a cumulatividade da percepção do auxílio financeiro a que se refere o caput deste artigo com benefícios de natureza semelhante recebidos em decorrência de outros programas federais, permitida a opção por um deles.

Art. $7^{\circ} \mathrm{O}$ órgão responsável pelas modalidades do Projovem definirá o agente pagador entre uma instituição financeira oficial.

Art. 8 As despesas com a execução do Projovem observarão os limites de movimentação, de empenho e de pagamento da programação orçamentária e financeira anual.

Parágrafo único. O Poder Executivo deverá compatibilizar a quantidade de beneficiários de cada modalidade do Projovem com as dotações orçamentárias existentes.

Art. 9o O Projovem Adolescente - Serviço Socioeducativo, compreendido entre os serviços de que trata o art. 23 da Lei no 8.742 , de 7 de dezembro de 1993, tem como objetivos:

I - complementar a proteção social básica à família, criando mecanismos para garantir a convivência familiar e comunitária; e

II - criar condições para a inserção, reinserção e permanência do jovem no sistema educacional.

Art. 10. O Projovem Adolescente - Serviço Socioeducativo destina-se aos jovens de 15 (quinze) a 17 (dezessete) anos:

I - pertencentes a família beneficiária do Programa Bolsa Família - PBF;

II - egressos de medida socioeducativa de internação ou em cumprimento de outras medidas socioeducativas em meio aberto, conforme disposto na Lei ํㅡ 8.069, de 13 de julho de 1990 Estatuto da Criança e do Adolescente;

III - em cumprimento ou egressos de medida de proteção, conforme disposto na Lei no 8.069, de 13 de julho de 1990;

IV - egressos do Programa de Erradicação do Trabalho Infantil - PETI; ou

$\mathrm{V}$ - egressos ou vinculados a programas de combate ao abuso e à exploração sexual. 
Parágrafo único. Os jovens a que se referem os incisos II a $\mathrm{V}$ do caput deste artigo devem ser encaminhados ao ProjovemAdolescente - Serviço Socioeducativo pelos programas e serviços especializados de assistência social do Município ou do Distrito Federal ou pelo gestor de assistência social, quando demandado oficialmente pelo Conselho Tutelar, pela Defensoria Pública, pelo Ministério Público ou pelo Poder Judiciário.

Art. 11. O Projovem Urbano tem como objetivo elevar a escolaridade visando à conclusão do ensino fundamental, à qualificação profissional e ao desenvolvimento de ações comunitárias com exercício da cidadania, na forma de curso, conforme previsto no art. 81 da Lei no 9.394, de 20 de dezembro de 1996.

Art. 12. O Projovem Urbano atenderá a jovens com idade entre 18 (dezoito) e 29 (vinte e nove) anos, que saibam ler e escrever e não tenham concluído o ensino fundamental.

Art. 13. Poderão ser realizadas parcerias com o Ministério da Justiça e com a Secretaria Especial dos Direitos Humanos da Presidência da República para implantação do Projovem Urbano nas unidades prisionais e nas unidades socioeducativas de privação de liberdade, respectivamente.

§ 1ㅇ O disposto no art. 4 desta Lei não será aplicado no caso das parcerias citadas no caput deste artigo, podendo ser realizado convênio, acordo, contrato, ajuste ou instrumento congênere.

$\S$ 2 № caso das unidades socioeducativas de privação de liberdade, poderão participar do Projovem Urbano adolescentes em cumprimento de medidas socioeducativas de privação de liberdade que tenham idade mínima de 15 (quinze) anos.

§ 3o É assegurada aos jovens que iniciaram o Projovem Urbano nas unidades do sistema prisional ou nas unidades socioeducativas de privação de liberdade a continuidade do curso nas localidades onde existir o Programa.

Art. 14. O Projovem Campo - Saberes da Terra tem como objetivo elevar a escolaridade dos jovens da agricultura familiar, integrando a qualificação social e formação profissional, na forma do art. 81 da Lei no 9.394, de 20 de dezembro de 1996, estimulando a conclusão do ensino fundamental e proporcionando a formação integral do jovem, na modalidade educação de jovens e adultos, em regime de alternância, nos termos do regulamento.

Art. 15. O Projovem Campo - Saberes da Terra atenderá a jovens com idade entre 18 (dezoito) e 29 (vinte e nove) anos, residentes no campo, que saibam ler e escrever, que não tenham concluído o ensino fundamental e que cumpram os requisitos previstos no art. 3 o da Lei no 11.326, de 24 de julho de 2006.

Art. 16. O Projovem Trabalhador tem como objetivo preparar o jovem para o mercado de trabalho e ocupações alternativas geradoras de renda, por meio da qualificação social e profissional e do estímulo à sua inserção.

Art. 17. O Projovem Trabalhador atenderá a jovens com idade entre 18 (dezoito) e 29 (vinte e nove) anos, em situação de desemprego e que sejam membros de famílias com renda mensal per capita de até 1 (um) salário-mínimo, nos termos do regulamento.

Art. 18. Nas unidades da Federação e nos Municípios onde existirem programas similares e congêneres ao previsto no ProjovemTrabalhador, o Ministério do Trabalho e Emprego buscará promover a articulação e a integração das ações dos respectivos Programas.

Art. 19. Na execução do Projovem Trabalhador, o Ministério do Trabalho e Emprego fica autorizado, mediante convênio, a efetuar transferências de contribuições corrente e de capital aos órgãos e entidades da administração pública federal, estadual e municipal, bem como a entidades de direito público e privado sem fins lucrativos, observada a legislação pertinente.

§ 1 $O$ regulamento disporá sobre critérios objetivos de habilitação e seleção de entidades privadas sem fins lucrativos para serem executoras do Projovem.

$\S$ 2ㅇ A habilitação e seleção das entidades referidas no $\S 10$ deste artigo serão processadas em estrita conformidade com os princípios básicos da legalidade, da impessoalidade, da moralidade, da igualdade, da publicidade e do julgamento objetivo.

Art. 20. Os arts. $2^{\circ}$ e $3^{\circ}$ da Lei no 10.836, de 9 de janeiro de 2004, passam a vigorar com a seguinte redação: 
II - o benefício variável, destinado a unidades familiares que se encontrem em situação de pobreza e extrema pobreza e que tenham em sua composição gestantes, nutrizes, crianças entre 0 (zero) e 12 (doze) anos ou adolescentes até 15 (quinze) anos, sendo pago até o limite de 3 (três) benefícios por família;

III - o benefício variável, vinculado ao adolescente, destinado a unidades familiares que se encontrem em situação de pobreza ou extrema pobreza e que tenham em sua composição adolescentes com idade entre 16 (dezesseis) e 17 (dezessete) anos, sendo pago até o limite de 2 (dois) benefícios por família.

$\S 2^{\circ}$ O valor do benefício básico será de $R \$ 58,00$ (cinqüenta e oito reais) por mês, concedido a famílias com renda familiar mensal per capita de até $R \$ 60,00$ (sessenta reais).

§ 3 Serão concedidos a famílias com renda familiar mensal per capita de até $R \$ 120,00$ (cento e vinte reais), dependendo de sua composição:

I - o benefício variável no valor de $\mathrm{R} \$ 18,00$ (dezoito reais); e

II - o benefício variável, vinculado ao adolescente, no valor de $\mathrm{R} \$ 30,00$ (trinta reais).

$\S$ 4 Os benefícios financeiros previstos nos incisos I, II e III do caput deste artigo poderão ser pagos cumulativamente às famílias beneficiárias, observados os limites fixados nos citados incisos II e III.

§ 50 A família cuja renda familiar mensal per capita esteja compreendida entre os valores estabelecidos no $\S 2^{\circ}$ e no $\S 3^{\circ}$ deste artigo receberá exclusivamente os benefícios a que se referem os incisos II e III do caput deste artigo, respeitados os limites fixados nesses incisos.

$\S 11$. Os benefícios a que se referem os incisos I, II e III do caput deste artigo serão pagos, mensalmente, por meio de cartão magnético bancário fornecido pela Caixa Econômica Federal, com a respectiva identificação do responsável, mediante o Número de Identificação Social NIS, de uso do Governo Federal.

$\S 12$. Os benefícios poderão ser pagos por meio das seguintes modalidades de contas, nos termos de resoluções adotadas pelo Banco Central do Brasil:

I - contas-correntes de depósito à vista;

II - contas especiais de depósito à vista;

III - contas contábeis; e

IV - outras espécies de contas que venham a ser criadas.

..$"(N R)$

"Art. 3o

Parágrafo único. O acompanhamento da freqüência escolar relacionada ao benefício previsto no inciso III do caput do art. 20 desta Lei considerará $75 \%$ (setenta e cinco por cento) de freqüência, em conformidade com o previsto no inciso VI do caput do art. 24 da Lei no 9.394, de 20 de dezembro de 1996." (NR)

Art. 21. Ato do Poder Executivo disporá sobre as demais regras de funcionamento de cada modalidade do Projovem, inclusive no que se refere ao estabelecimento de metas, à avaliação, ao monitoramento e ao controle social, e sobre os critérios adicionais a serem observados para o ingresso no Programa, bem como para a concessão, a manutenção e a suspensão do auxílio a que se refere 0 art. 6ㅇesta Lei.

$\S 1^{\circ}$ Cumpridos os requisitos estabelecidos nesta Lei e na sua regulamentação, ficam asseguradas aos jovens com deficiência as condições que lhes possibilitem a efetiva participação no Projovem. 
$\S 2$ ㅇ Nos currículos dos cursos oferecidos nas modalidades de que trata 0 art. 20 desta Lei deverão ser incluídas noções básicas de comunicação oral e escrita em língua portuguesa, de matemática, de informática, de cidadania e de língua estrangeira.

Art. 22. O Poder Executivo deverá veicular dados e informações detalhados sobre a execução orçamentária e financeira dos Programas Projovem e Bolsa Família, tratados nesta Lei.

Art. 23. Esta Lei entra em vigor na data de sua publicação.

Parágrafo único. Aos beneficiários e executores dos Programas disciplinados nas Leis nos 10.748, de 22 de outubro de 2003,11.129, de 30 de junho de 2005, e 11.180, de 23 de setembro de 2005, ficam assegurados, no âmbito do Projovem, os seus direitos, bem como 0 cumprimento dos seus deveres, nos termos dos convênios, acordos ou instrumentos congêneres firmados até 31 de dezembro de 2007.

Art. 24. Ficam revogados, a partir de $1^{\circ}$ de janeiro de 2008:

I - 0 art. 3--A da Lei no 9.608, de 18 de fevereiro de 1998;

II - a Lei no 10.748, de 22 de outubro de 2003;

III - os arts. $1^{\circ}, 2^{\circ}$ e $3^{\circ}$ da Lei no 10.940 , de 27 de agosto de 2004;

IV - os arts. 10 a 8 da Lei no 11.129, de 30 de junho de 2005; e

V - os arts. $1^{\circ}$ a 10 da Lei no 11.180, de 23 de setembro de 2005. 
ANEXO 5 - DECRETO № 26.132, DE 24 DE AGOSTO DE 2005.

DODF DE 25.08.2005

Cria o Comitê Gestor do Programa de Inclusão de Jovens -ProJovem, no Distrito Federal, e dá outras providências.

O GOVERNADOR DO DISTRITO FEDERAL, no uso das atribuições que the confere o artigo 100, incisos VII e X, da Lei Orgânica do Distrito Federal, e as decorrentes da assinatura do Termo de Adesão conforme Processo no 00030.000463/2005-37, estabelecido entre o Governo do Distrito Federal e a União, visando o desenvolvimento de ações e atividades do ProJovem no Distrito Federal, na forma das disposições contidas na Lei $\mathrm{n}^{0} \mathbf{1 1 . 1 2 9}$, de 30 de junho de 2005, DECRETA:

Art. 10 Fica criado o Comitê Gestor do Programa de Inclusão de Jovens: Educação, Qualificação e Ação Comunitária ProJovem, no Distrito Federal, vinculado a Secretaria de Estado de Trabalho, na forma deste Decreto.

Art. 2ํ- O Comitê Gestor é constituído por titulares dos órgãos governamentais, não governamentais e entidade representativa da juventude, designados por ato do Governador do Distrito Federal.

$\S 1^{\circ}$ - A supervisão do Comitê Gestor será exercida pela Agencia de Desenvolvimento Social do Distrito Federal, com a incumbência precípua de articular a execução do ProJovem, dirimir conflitos e evitar superposição de tarefas.

$\S 2^{\circ}$ Cada membro terá um suplente a ser indicado pelo titular.

Art. 3-- Quando houver impedimento da participação do representante, titular das Pastas do GDF, nas atividades do Comitê, seu substituto será o Secretário Adjunto.

Art. 4-- Compõem o Comitê os seguintes órgãos e entidades:

I - Secretaria de Estado de Trabalho;

II- Secretaria de Estado de Educação;

III - Secretaria de Estado de Ação Social;

IV- Secretaria de Estado de Governo;

V- Secretaria de Estado de Cultura;

VI - Secretaria de Estado de Solidariedade;

VII - União Metropolitana dos Estudantes Secundários do Distrito Federal - UMESB;

VIII-Serviço Brasileiro de Apoio as Micro e Pequenas Empresas do Distrito Federal SEBRAE/DF.

Parágrafo único. A presidência do Conselho Gestor caberá ao titular da Secretaria de Estado de Trabalho do Distrito Federal.

Art.5ำ - Caberá ao Comitê Gestor do ProJovem promover a articulação e a mobilização das entidades parceiras, visando a integração dos esforços do Governo e da sociedade civil para a elevação da escolaridade e da qualificação profissional dos jovens .

Art. 6ㅇ - Para cumprimento das ações de planejamento e supervisão do Programa ProJovem, no Distrito Federal, será criada a Comissão Estratégica, coordenada pela Secretaria de Trabalho e composta por dois representantes de cada órgão e entidade relacionados no Art. $4^{\underline{0}}$ deste Decreto.

Parágrafo Único- A Secretaria de Estado de Trabalho indicará 5 (cinco) representantes, sendo 1 (um) da Assessoria Especial do Gabinete, 2 (dois) da Subsecretaria de Emprego e 2 (dois) da Subsecretaria da Juventude para comporem a Comissão prevista no caput.

Art. 7ํ- A operacionalização do programa ficará a cargo da Coordenação Distrital, a ser criada pelo Comitê Gestor, mediante proposição da Comissão Estratégica, que atuará respeitando as diretrizes do Projeto Pedagógico Integrado, definido pela Coordenação Nacional de Inclusão de Jovens - ProJovem, integrante da Secretaria Nacional da Juventude, vinculada à Secretaria 
Geral da Presidência da República..

Art. 8-- Este Decreto entra em vigor na data de sua publicação.

Brasília, 24 de agosto de 2005

$117^{\circ}$ da República e $46^{\circ}$ de Brasília

JOAQUIM DOMINGOS RORIZ 